\title{
Synthesis of heterocyclic compounds based on isatin through 1, 3- dipolar cycloaddition reactions
}

\author{
Negar Lashgari and Ghodsi Mohammadi Ziarani* \\ Department of Chemistry, Alzahra University, Vanak Square, Tehran, P. O. Box 1993891176, \\ Iran \\ E-mail: gmziarani@hotmail.com
}

\begin{abstract}
This review gives an overview of the advances in the use of isatin in the synthesis of various heterocyclic compounds via 1,3-dipolar cycloaddition reactions during the period from 2000 to 2011.
\end{abstract}

Keywords: Isatin, 1,3-dipolar cycloaddition reaction, heterocycles, spirooxindole pyrrolidine

\section{Table of Contents}

1. Introduction

2. Synthesis of Monospiropyrrolo/pyrrolizidino-oxindole Ring Systems

3. Synthesis of Dispiropyrrolo/pyrrolizidino-oxindole Ring Systems

3.1. Synthesis of dispiropyrrolothiazolo-oxindoles

4. Synthesis of Trispiroheterocycles

5. Synthesis of Tetraspiroheterocycles

6. Acknowledgements

7. References

\section{Introduction}

The biological and pharmacological properties of isatin and its derivatives have led to extensive use of these compounds as key intermediates in organic synthesis. ${ }^{1}$ Isatin is a core constituent of many alkaloids ${ }^{2}$ and drugs $^{3}$ as well as dyes, ${ }^{4}$ pesticides and analytical reagents. Literature surveys reveal that various derivatives of isatin possess diverse activities such as antibacterial, ${ }^{5}$ antifungal, ${ }^{6}$ antiviral, ${ }^{7}$ anti-HIV ${ }^{8}$ anti-mycobacterial, ${ }^{9}$ anticancer, ${ }^{10}$ anti-inflammatory ${ }^{11}$ and anticonvulsant activities. $^{12}$ 
Furthermore, isatins with their multifunctionality and diversity of transformations are synthetically versatile substrates and many efforts have been made toward the synthesis of these compounds.

1,3-Dipolar cycloaddition, also known as the Huisgen reaction, ${ }^{13}$ is regarded as one of the most attractive methods for the formation of pharmacologically important five-membered $\mathrm{N}$ heterocyclic compounds. 1,3-Dipolar cycloaddition of ylidic species such as azomethine ylides with dipolarophiles provides an efficient and convergent approach for constructing pyrrolidine rings which are classes of compounds with significant biological activities.

Considering isatin as an important building block in organic synthesis, and since there is a wide range of reactions that include isatin in the synthesis of heterocyclic compounds, in the present review the focus is on applications of isatin in 1,3-dipolar cycloaddition reactions from reports that have been published after 2000 .

\section{Synthesis of Monospiropyrrolo/pyrrolizidino-oxindole Ring Systems}

Bergman and coworkers condensed isatin $\mathbf{1}$ with a number of $\alpha$-amino acid derivatives $\mathbf{2}$ in a methanol/water medium. Formation of the anti-azomethine ylides $\mathbf{3}$ followed by the 1,3-dipolar addition of the dipolarophiles 4 yielded the pyrrolidine-2-spiro-3-(2-oxindole)s 5 (Scheme 1). ${ }^{14}$

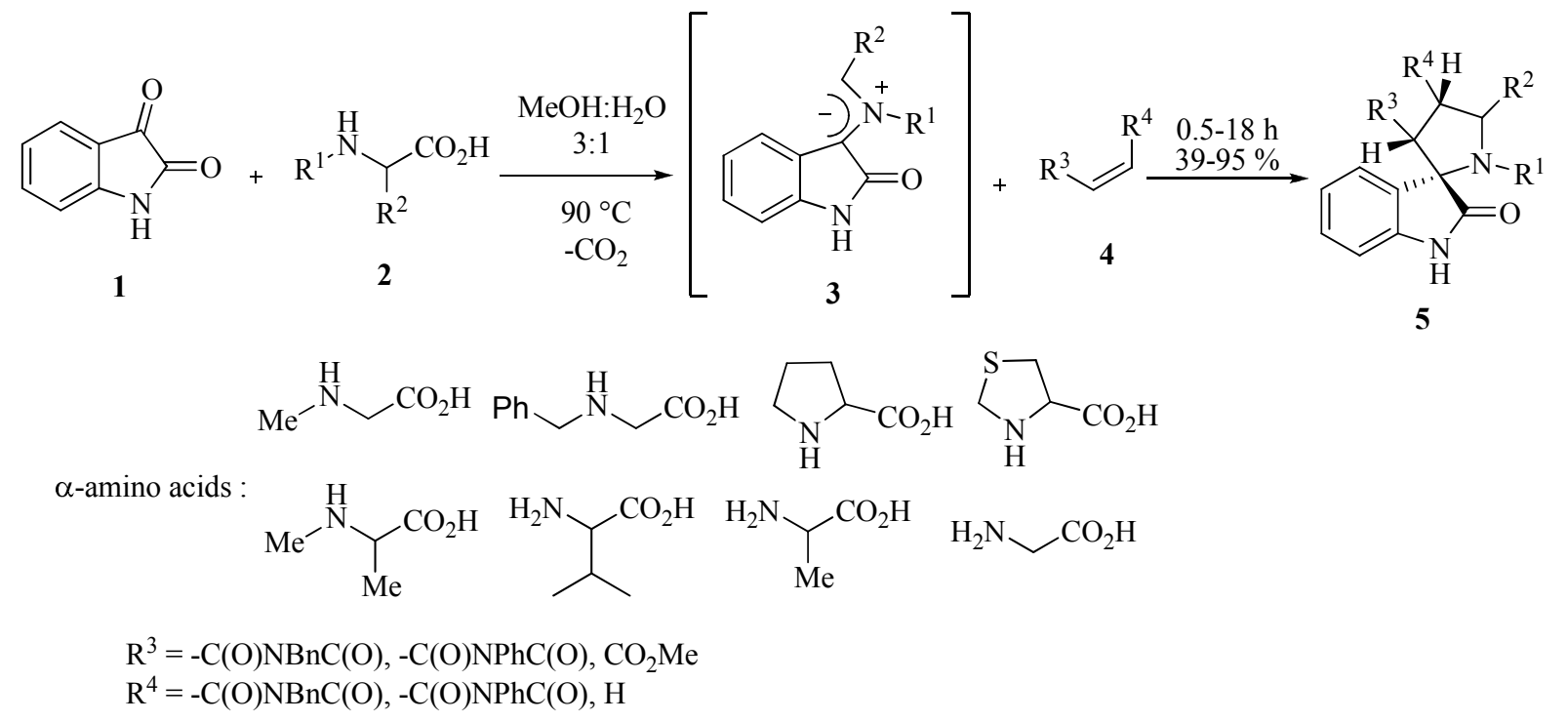

\section{Scheme 1}

The synthesis of spiropyrrolizidine oxindoles $\mathbf{8}$ containing two ester groups or two amide groups has been reported. In this reaction maleates or maleamides $\mathbf{7}$ act as dipolarophiles (Scheme 2). ${ }^{15}$ 


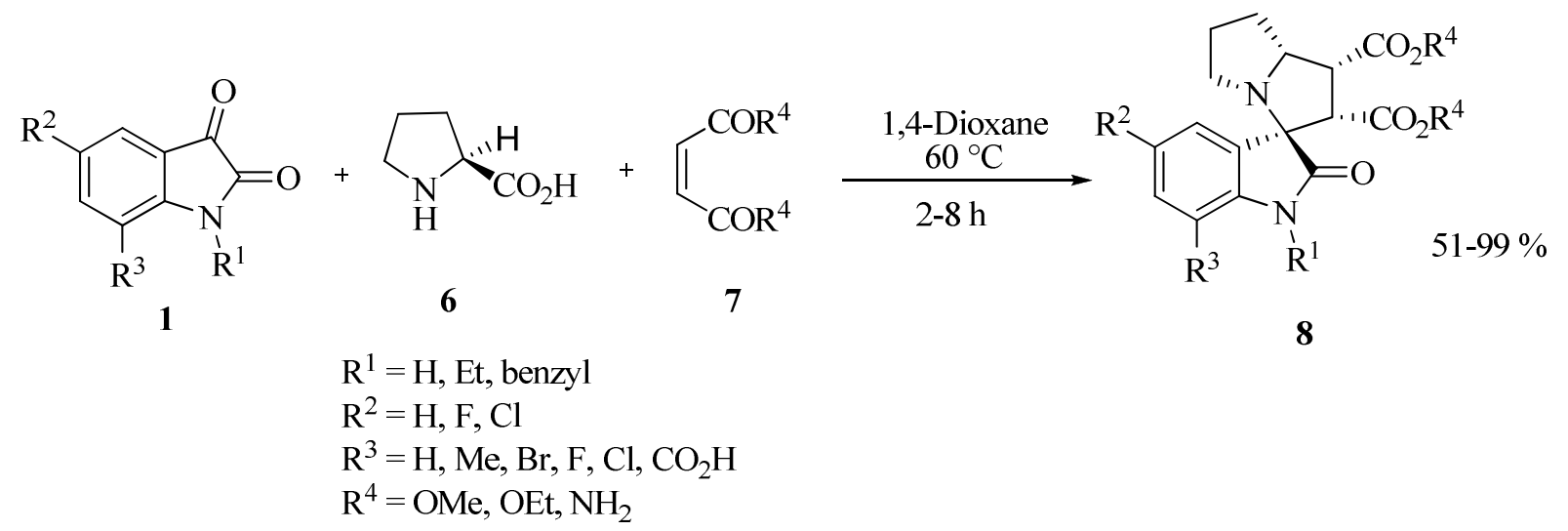

\section{Scheme 2}

The regio- and stereochemical 1,3-dipolar cycloaddition reaction of the azomethine ylides, which were generated in situ by the reaction of isatin derivatives and proline, with trans- $\beta$ nitrostyrene 9 and (E)-1-phenyl-2-nitropropene $\mathbf{1 0}$ were studied both experimentally and theoretically (Scheme 3). ${ }^{16}$ In a related study, Chen and coworkers reported their new findings in the 1,3-dipolar cycloaddition reactions of isatin, $\alpha$-amino acids 2 , and $(E)$ - $\beta$-nitro-styrenes 9 with different regioselectivity (Scheme 4). ${ }^{17}$ Perumal and coworkers evaluated these compounds for their in vitro activity against Mycobacterium tuberculosis H37Rv (MTB). ${ }^{18}$

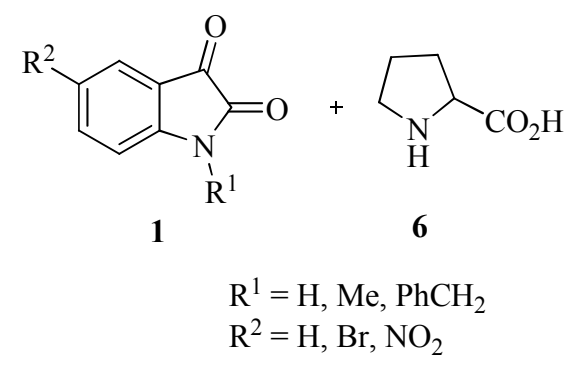

$\mathrm{R}^{1}=\mathrm{H}, \mathrm{Me}, \mathrm{PhCH}_{2}$
$\mathrm{R}^{2}=\mathrm{H}, \mathrm{Br}, \mathrm{NO}_{2}$

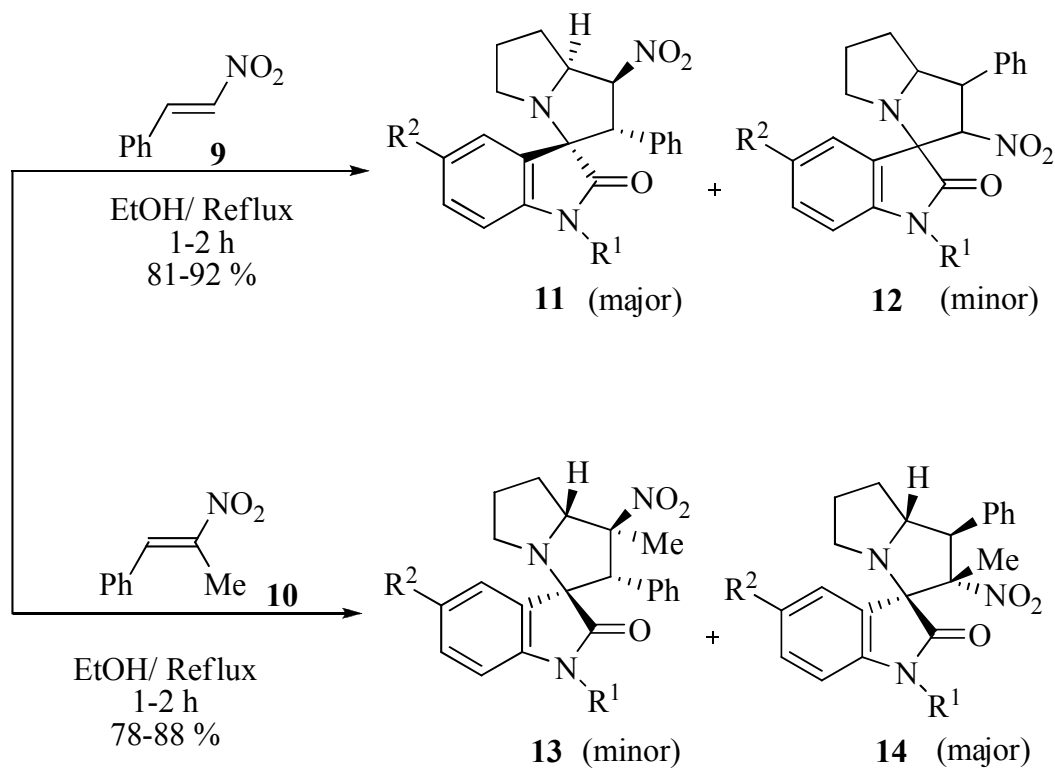

\section{Scheme 3}




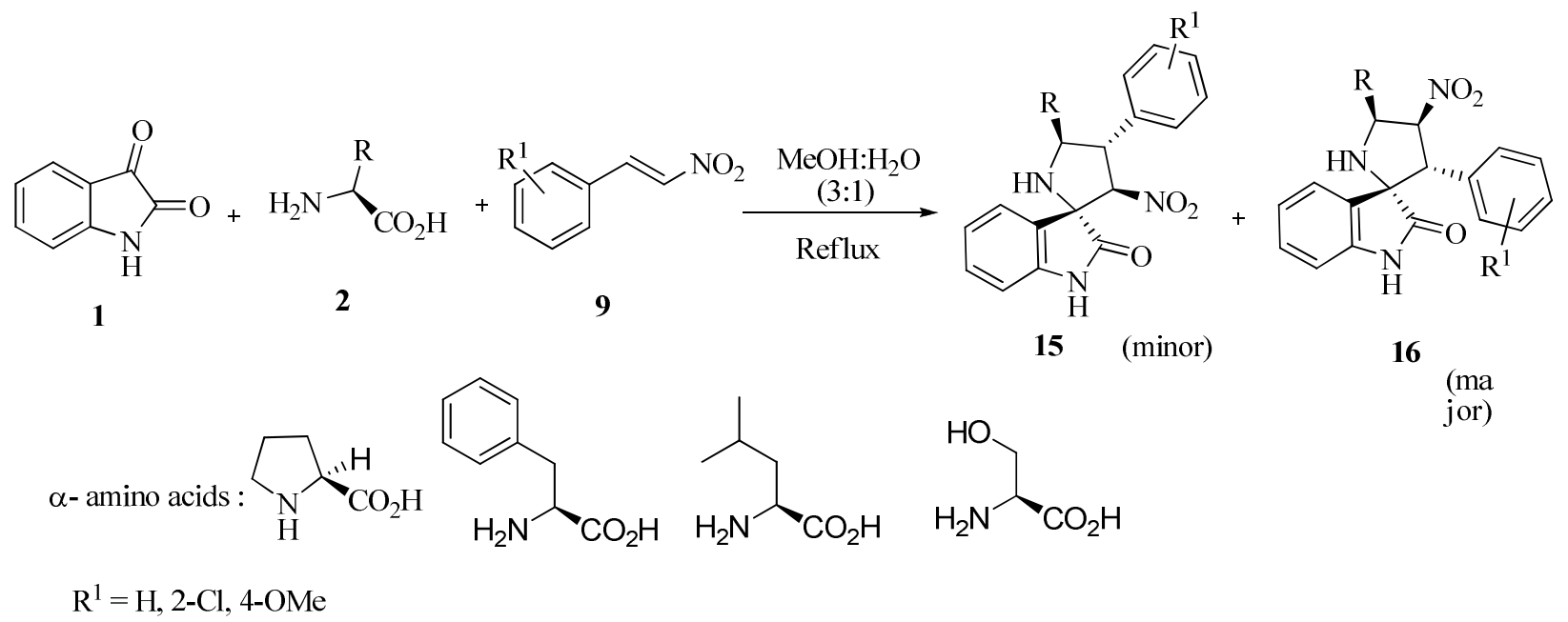

\section{Scheme 4}

$\beta$-Nitrostyrene 9 was also used in reaction with non-stabilized azomethine ylides generated from isatin 1 with sarcosine 17, resulting in the formation of a series of spiro-oxindolonitropyrrolidines $\mathbf{1 8}$ in good yields (Scheme 5). ${ }^{19}$

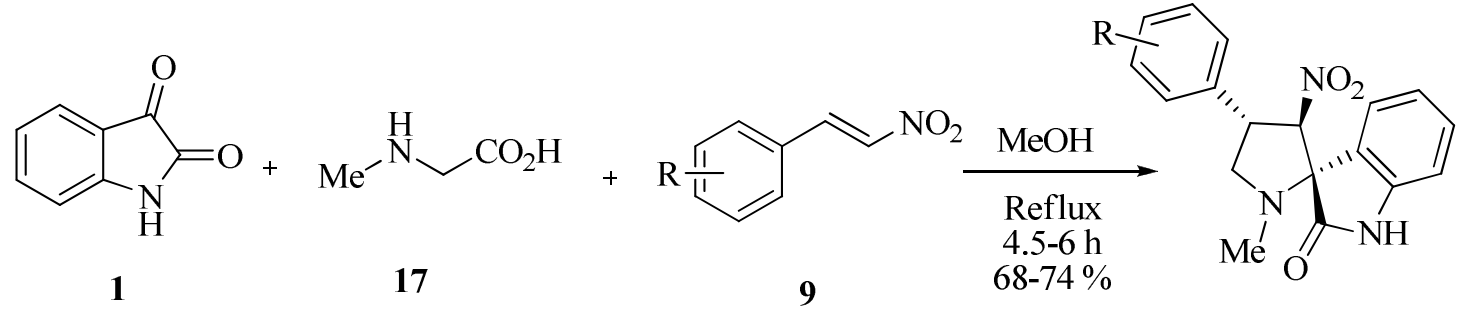

$$
\mathrm{R}=\mathrm{H}, p \text {-Me, } p \text {-OMe, } m-\mathrm{NO}_{2}, p-\mathrm{Cl}, o-\mathrm{Cl}
$$

\section{Scheme 5}

The [3+2]-cycloaddition reaction of 3-acetylcoumarins $\mathbf{1 9}$ with azomethine ylides in toluene under reflux for $18 \mathrm{~h}$ afforded chromene bearing novel spiropyrrolidine-oxindoles $\mathbf{2 0}$. The products 21 were surprisingly obtained when the reactions were carried out in methanol under reflux conditions for $15 \mathrm{~h}$ (Scheme 6). ${ }^{20}$ The results show that the reaction in methanol was accompanied by deacetylation, presumably by nucleophilic attack of methanol at the COMe group. 


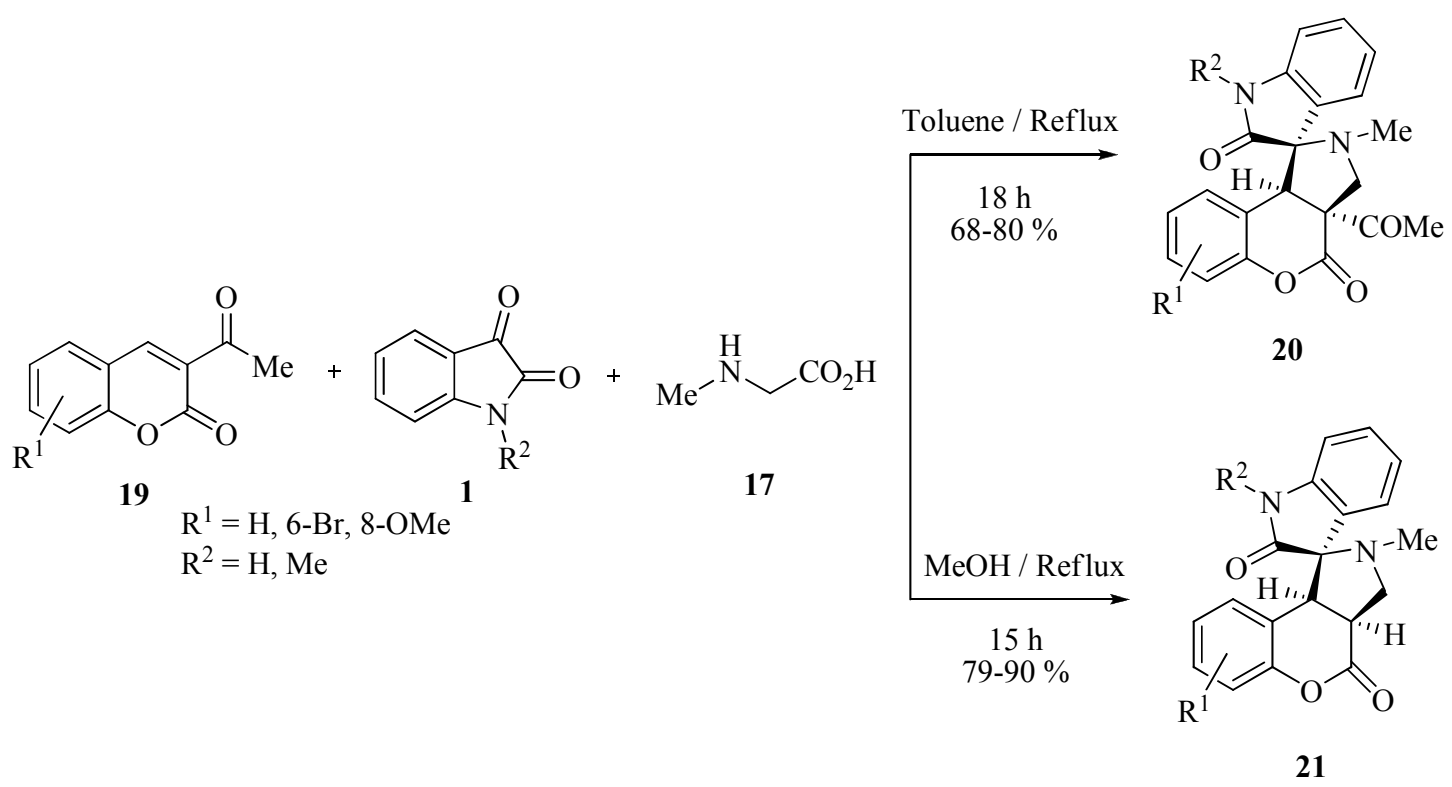

\section{Scheme 6}

Chen and coworkers published a study of reactions of isatin, $\alpha$-amino acids and 1,4naphthoquinone 22 using ultrasound in methanol at about $40{ }^{\circ} \mathrm{C}$ to afford a series of 3spiro[pyrrolidino-oxindoles] derivatives 23 (Scheme 7). ${ }^{21}$<smiles>[R]NC([R])C(=O)O</smiles>

amino acids : L-Proline, L-Isoleucine, L-Penylalanine, L-Tryptophan, L-Valine

\section{Scheme 7}

Dipolarophiles 24 and 25 derived from galactose have been reacted with azomethine ylides generated from isatin and secondary amino acids to give the corresponding spiroglycoheterocycles 26-29 in good yields (Scheme 8). ${ }^{22}$ 

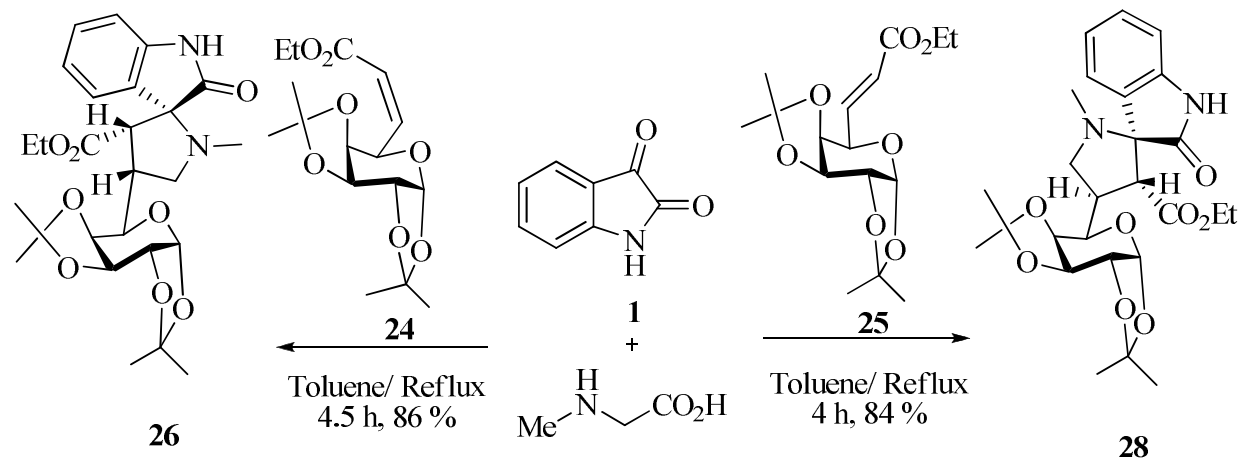

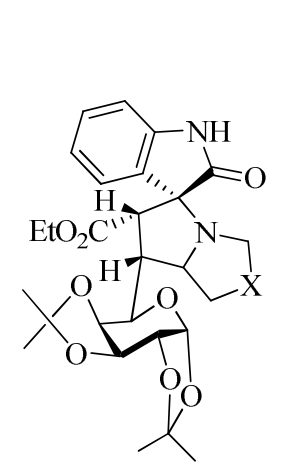

27

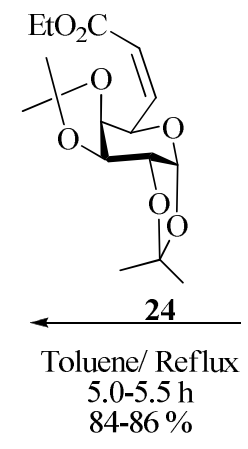

$84-86 \%$

17

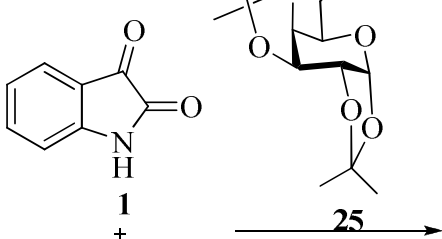

Toluene/ Reflux $4.5-5.5 \mathrm{~h}$ $82-88 \%$

6

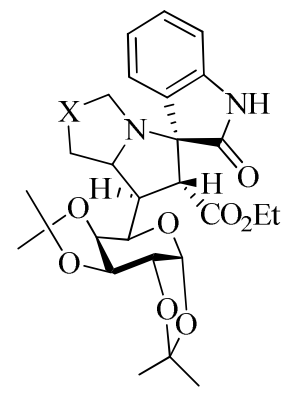

29

$\mathrm{X}=\mathrm{CH}_{2}, \mathrm{~S}$

\section{Scheme 8}

One-pot reactions of various $\alpha, \beta$-unsaturated $\beta$-C-glycosidic ketones $\mathbf{3 0}$ with the azomethine ylides resulted in the formation of novel sugar-based monospirooxindole-pyrrolidines $\mathbf{3 1}$ and 32 in $69-85 \%$ yields (Scheme 9 ). ${ }^{23}$

In another study, application of the 1,3-dipolar cycloaddition reaction of an azomethine ylide with a carbohydrate-derived olefin $\mathbf{3 3}$ has been reported by Banerjee and coworkers. In this study, a series of sugar-fused spiro-pyrrolidine, -pyrrolizidine, and -indolizidine heterocycles 34 and 35 were synthesized (Scheme 10). ${ }^{24}$ 


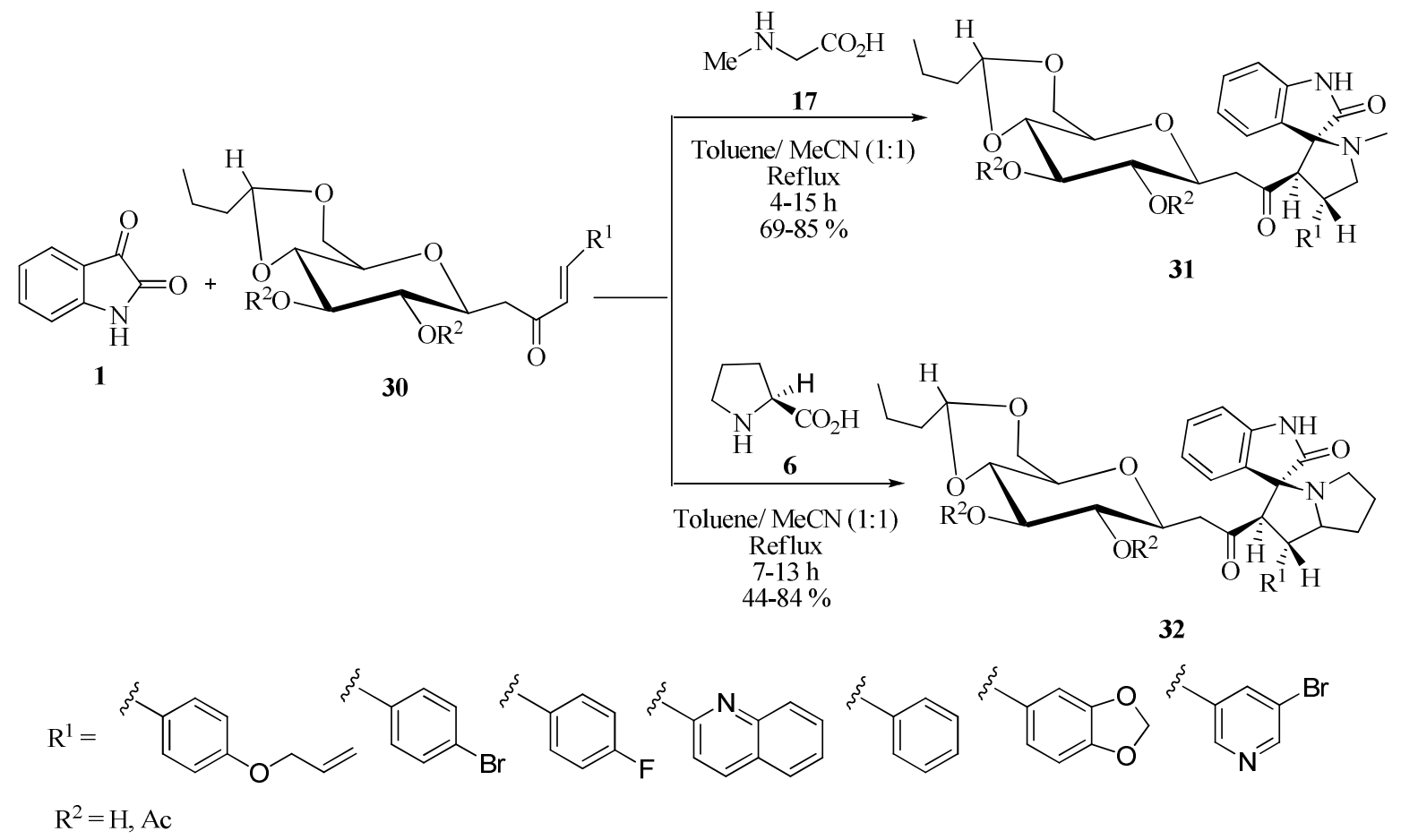

Scheme 9

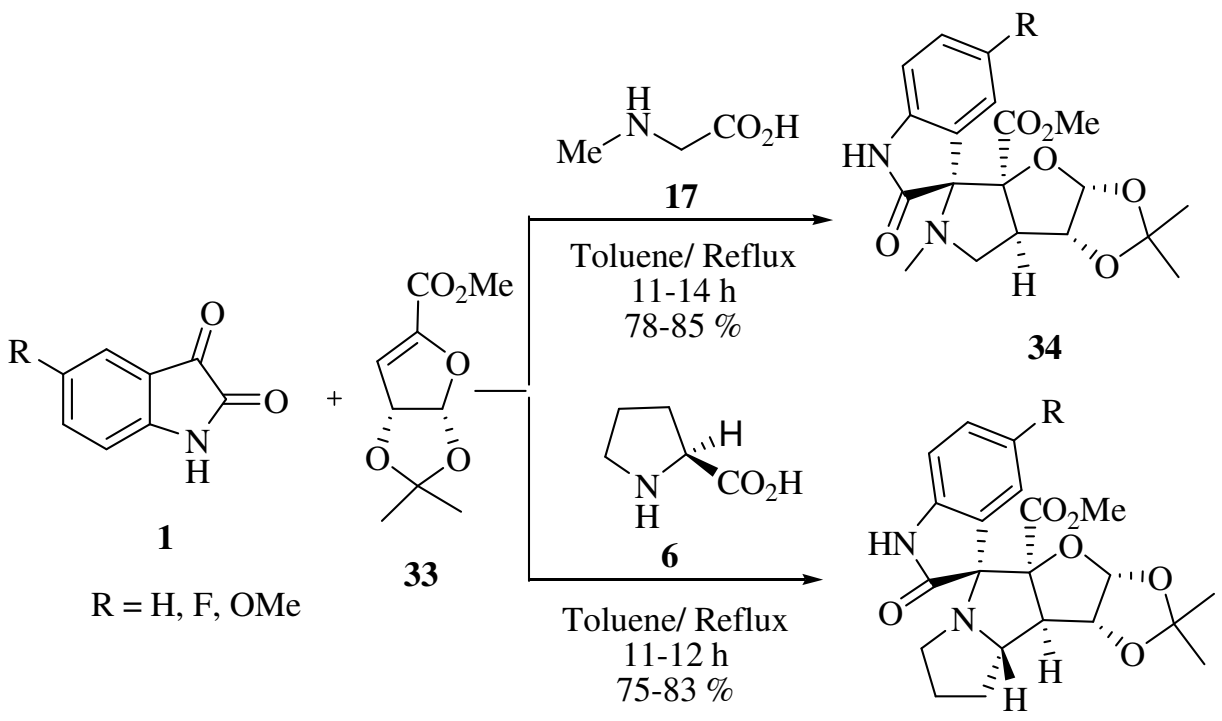

35

\section{Scheme 10}

A synthetic route for the preparation of a novel class of dicyano- functionalised spiropyrrolidine $\mathbf{3 7}$ and spiropyrrolizidine $\mathbf{3 8}$ from the reaction of various arylidenemalononitrile Knoevenagel adducts 36 with non-stabilized azomethine ylides generated from isatin and $\alpha$ - 
amino acids (sarcosine/ $N$-phenylglycine/proline) has been developed (Scheme 11). ${ }^{25}$ The reactions were carried out under both conventional heating and ultrasonic irradiation conditions.<smiles>[R]c1ccc([C@H]2CN([R])[C@]3(C(=O)Nc4ccccc43)C2(C#N)C#N)cc1</smiles>

37<smiles></smiles>

$\mathrm{R}^{1}=4-\mathrm{Me}, 4-\mathrm{Cl}, 3-\mathrm{Br}, 4-\mathrm{Br}, \mathrm{H}, 4-\mathrm{F}, 4,3-\mathrm{OMe}$ $\mathrm{R}^{2}=\mathrm{Me}, \mathrm{Ph}$

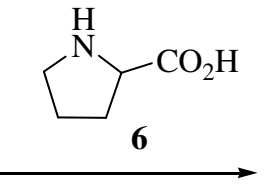

$\Delta(4 \mathrm{~h}, 70 \%)$ ))) (100 $\min , 81 \%)$<smiles>[R][X]C1(C#N)[C@H](c2ccccc2)[C@@H]2CCCN2[C@]12C(=O)Nc1ccccc12</smiles>

38

\section{Scheme 11}

When various derivatives of trisbenzylidene acetylacetone $\mathbf{3 9}$ as unusual dipolarophiles were subjected to 1,3-dipolar cycloaddition with the azomethine ylides, novel spiroheterocycles 40, 41, and 44 with high regio- and stereoselectivity were obtained (Scheme 12). ${ }^{26}$

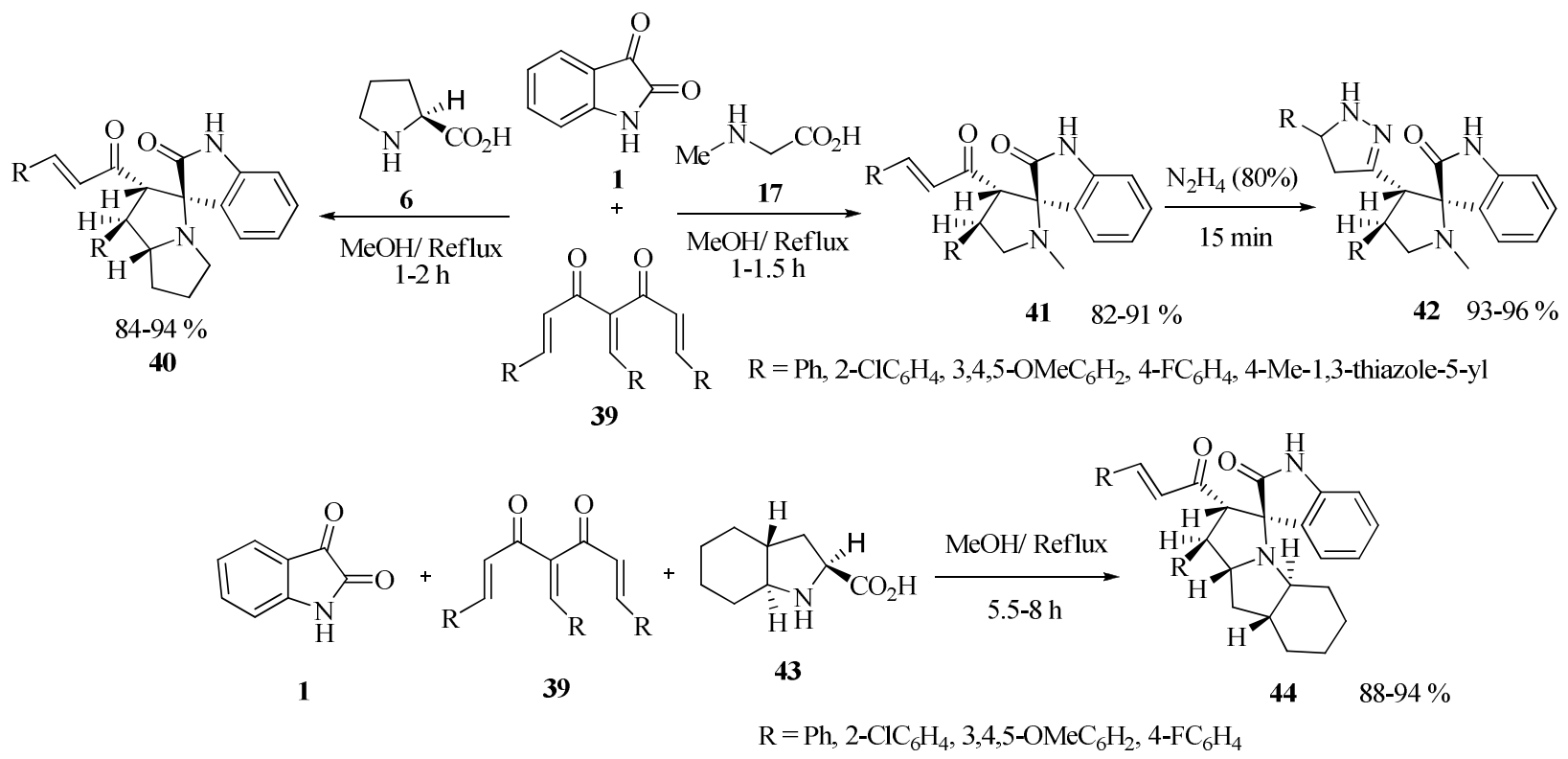

\section{Scheme 12}

Acenaphthoquinone $\mathbf{4 5}$ as a 1,2-dione in reaction with isatin and sarcosine afforded a mixture of two products, 46 and 47 (Scheme 13). ${ }^{27}$ 


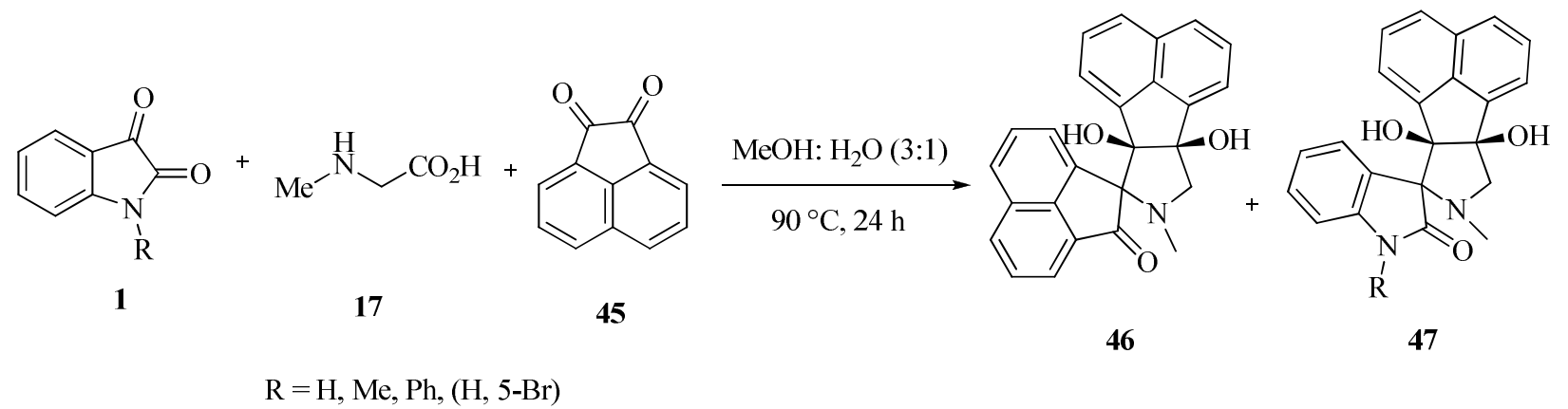

Scheme 13

The reaction of various porphyrin derivatives 48 with the azomethine ylide generated from isatin/ $N$-benzylisatin and sarcosine in refluxing toluene afforded a series of novel chlorin-fused monospirooxindolopyrrolidines $\mathbf{4 9}$ in good yield via a facile [3+2]-cycloaddition reaction (Scheme 14). ${ }^{28}$

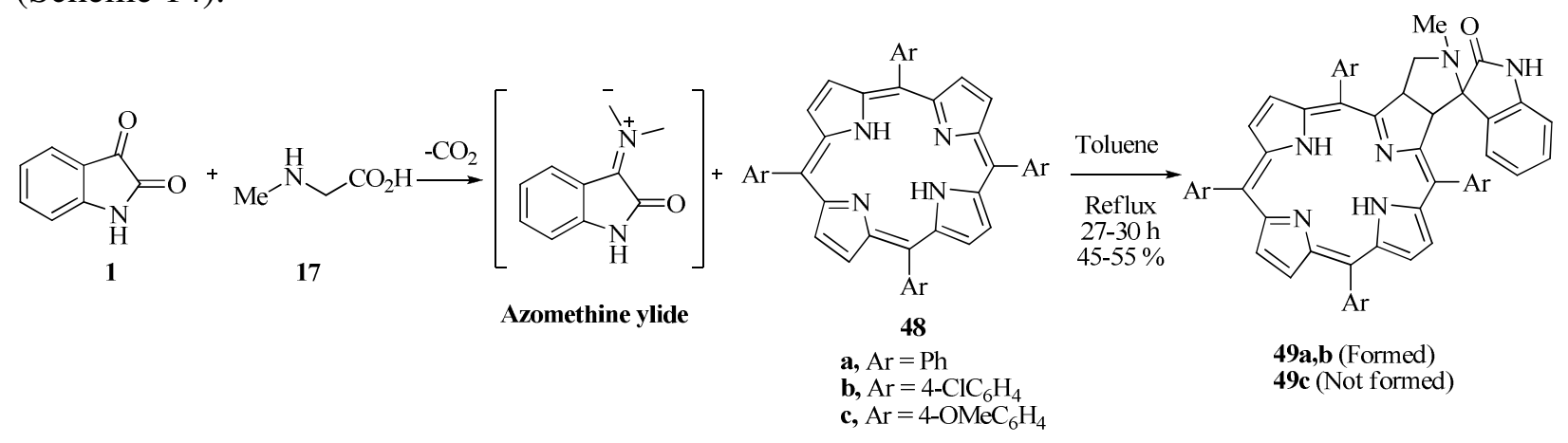

\section{Scheme 14}

The intermediate azomethine ylide 50 (derived from $\mathrm{Ni}$ (II) $\beta$-formyl-meso-tetraphenylporphyrin in the presence of $N$-methylglycine) and its 1,3-dipolar cycloaddition with isatin to give the porphyrin derivatives $\mathbf{5 2}$ was also reported (Scheme 15). ${ }^{29}$

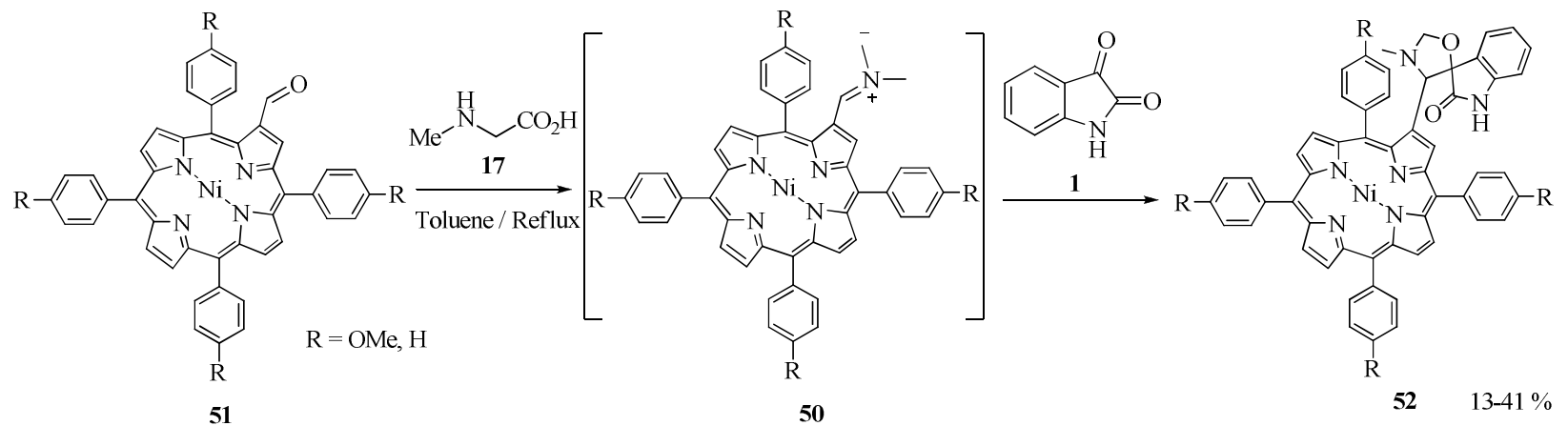

Scheme 15

One-pot synthesis of novel ferrocenyl monospirooxindolopyrrolidines $\mathbf{5 4}$ has been accomplished in good yield via a facile [3+2]-cycloaddition reaction of several azomethine 
ylides, derived from isatin/5,7-dibromoisatin and sarcosine, with various unusual ferrocene derivatives 53 as dipolarophilic partners (Scheme 16). ${ }^{30}$
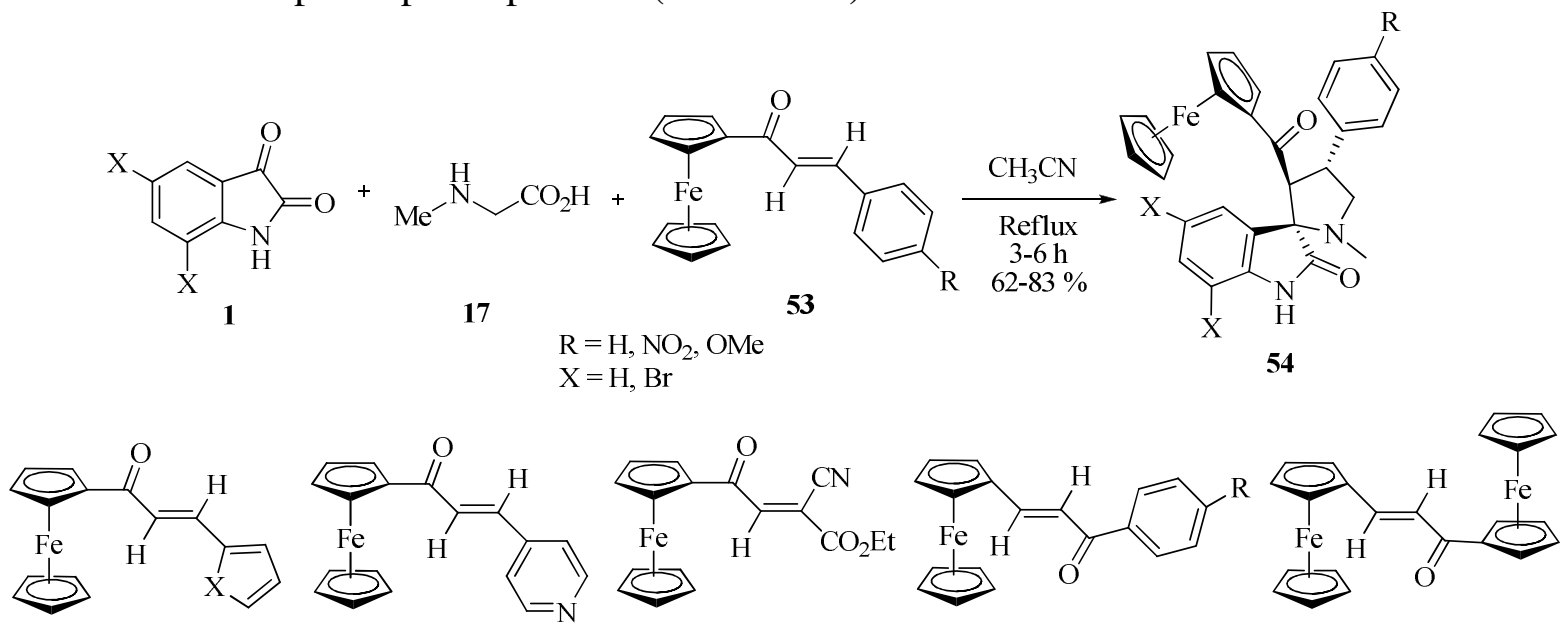

\section{Scheme 16}

This reaction was also carried out with L-proline 6 in place of sarcosine (Scheme 17). ${ }^{31}$<smiles>[R]CN[R16](=O)[O-]</smiles>

\section{Scheme 17}

The one-pot, three-component condensation of sarcosine or proline Schiff bases with several aromatic aldehydes 57 and the Knoevenagel adduct 2-(2-oxoindolin-3-ylidene)malononitrile derivatives 56 successfully afforded spiropyrrolidine-oxindoles 58 and 59 and spiropyrrolizineoxindoles 60 and 61 (Scheme 18). ${ }^{32}$ 


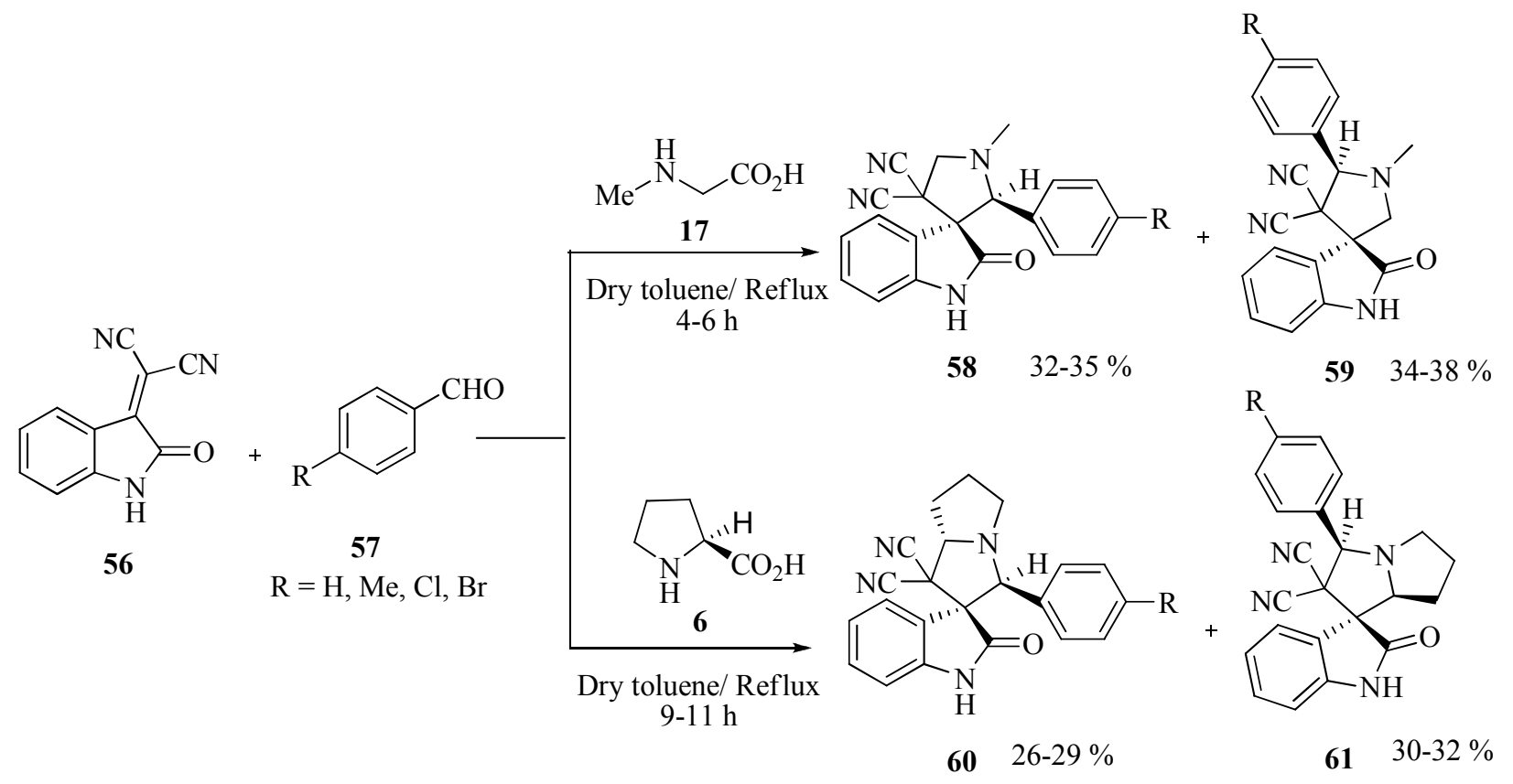

\section{Scheme 18}

A multicomponent [3+2] cycloaddition reactions of 3-cyanoacetylindoles $\mathbf{6 2}$, aldehydes 57, isatin $\mathbf{1}$ and amino acids $\mathbf{6}$ and $\mathbf{1 7}$ was reported by Xu and coworkers (Scheme 19). ${ }^{33}$<smiles>N#CCC(=O)c1c[nH]c2cc[Y]cc12</smiles>

62<smiles>O=c1[nH]c2cc[R]ccc=2c1=O</smiles>

1
$\mathrm{ArCHO}$

57

$\mathrm{R}^{1}=\mathrm{H}, 5-\mathrm{Me}, 6-\mathrm{Me}, 7-\mathrm{Me}, 5-\mathrm{Br}$

$\mathrm{R}^{2}=\mathrm{H}, 6-\mathrm{Br}, 5-\mathrm{Cl}, 5-\mathrm{Me}$

$\mathrm{Ar}=4-\mathrm{BrC}_{6} \mathrm{H}_{4}, 4-\mathrm{ClC}_{6} \mathrm{H}_{4}, 4-\mathrm{NO}_{2} \mathrm{C}_{6} \mathrm{H}_{4}, \mathrm{Ph}, 4-\mathrm{MeC}_{6} \mathrm{H}_{4}$

57
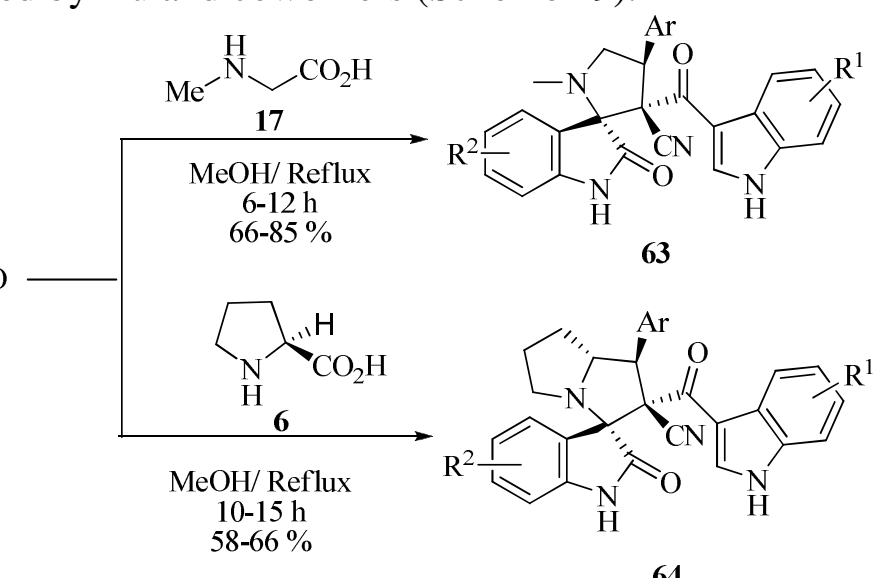

\section{Scheme 19}

The reaction of $\mathrm{N}$-phenyl isatin with proline and 65 in aqueous dioxane at $80-90{ }^{\circ} \mathrm{C}$ for $3 \mathrm{~h}$ yielded $66(98 \%)$ as the only diastereoisomer. Reduction of 66 with excess of lithium borohydride in aqueous tetrahydrofuran yielded a mixture of $67(25 \%)$ and $\mathbf{6 8}(25 \%)$ (Scheme 20). ${ }^{34}$ 


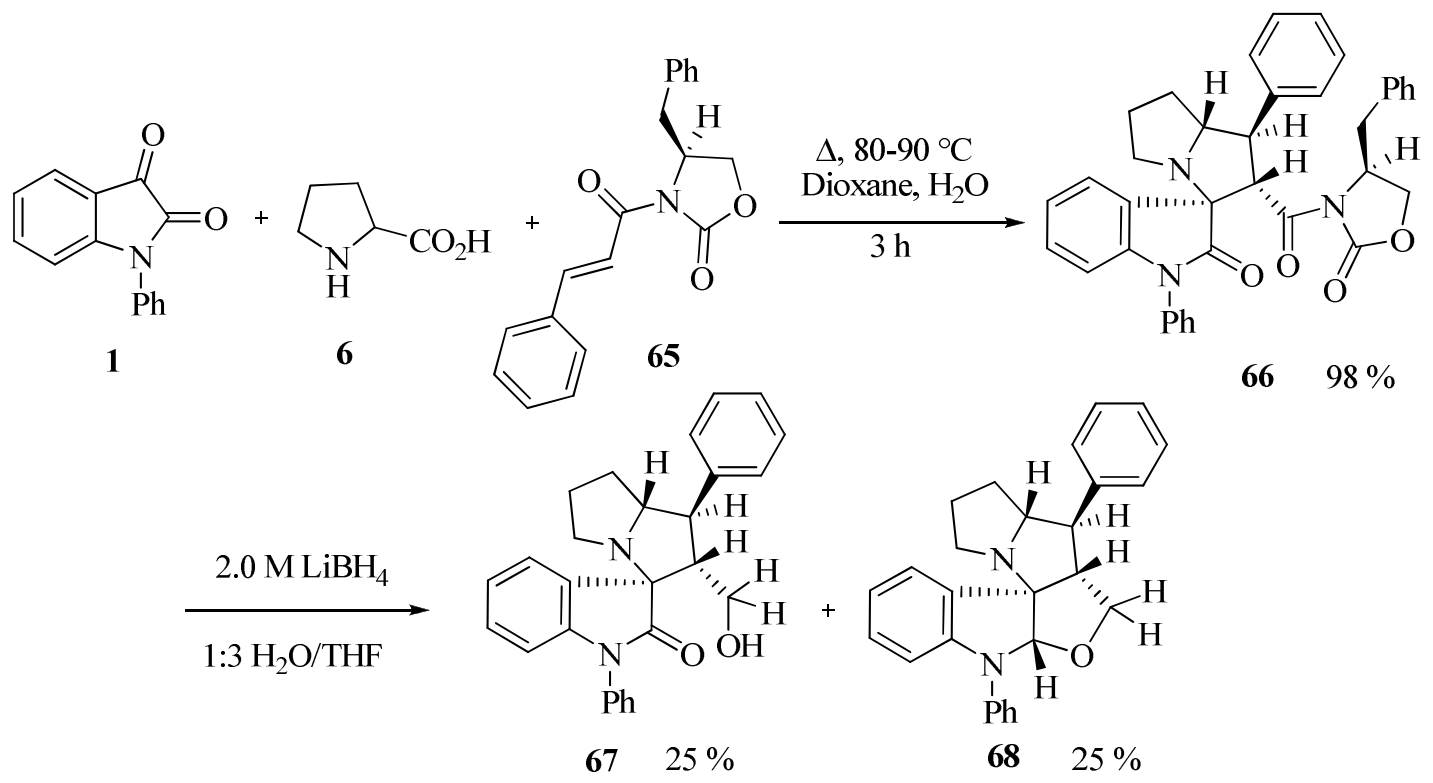

\section{Scheme 20}

The cycloaddition reaction of azomethine ylides generated by the reaction of isatin and sarcosine, with the olefinic bond of Baylis-Hillman adducts 69 gave the corresponding cycloadducts $\mathbf{7 0}$ as single regioisomers as disclosed by Raghunathan and coworkers (Scheme 21). ${ }^{35}$<smiles>[R]c1ccc(C(O)C(=C)C(=O)OC)cc1</smiles>

69
$\mathrm{R}=\mathrm{H}, \mathrm{Cl}, \mathrm{Me}$<smiles>O=C1Nc2ccccc2C1=O</smiles>

1

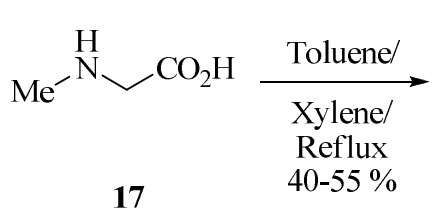

17

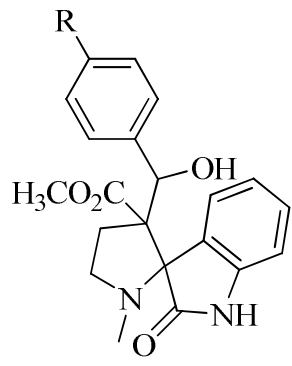

$\mathbf{7 0}$

\section{Scheme 21}

A series of spirooxindoles containing tri- and tetracyclic fused pyrrolo-benzothiophene 1,1dioxide derivatives 72 and $\mathbf{7 3}$ were synthesized regioselectively via a multicomponent 1,3dipolar cycloaddition of isatin, 1-benzothiophene 1,1-dioxide $\mathbf{7 1}$ and sarcosine or L-proline (Scheme 22). ${ }^{36}$ 


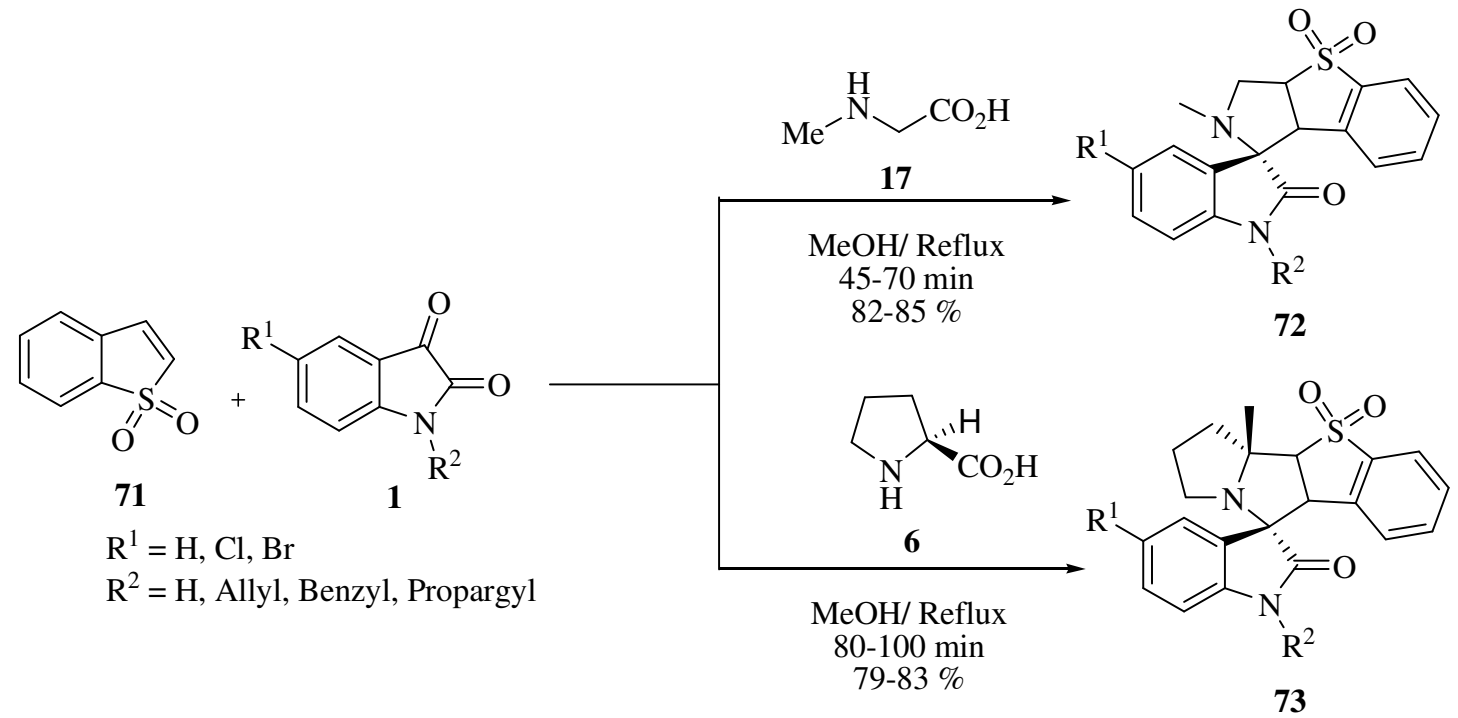

\section{Scheme 22}

Reaction of (E)-3-aryl-1-(thiophen-2-yl)prop-2-en-1-ones 74 with the azomethine ylide generated by the reaction of isatin and proline in refluxing methanol afforded the products $\mathbf{7 5}$ in a regiospecific manner (Scheme 23). ${ }^{37}$ The compounds synthesized were screened for their antibacterial and antifungal activities.<smiles>O=C(O)[C@H]1CCCN1</smiles>

6

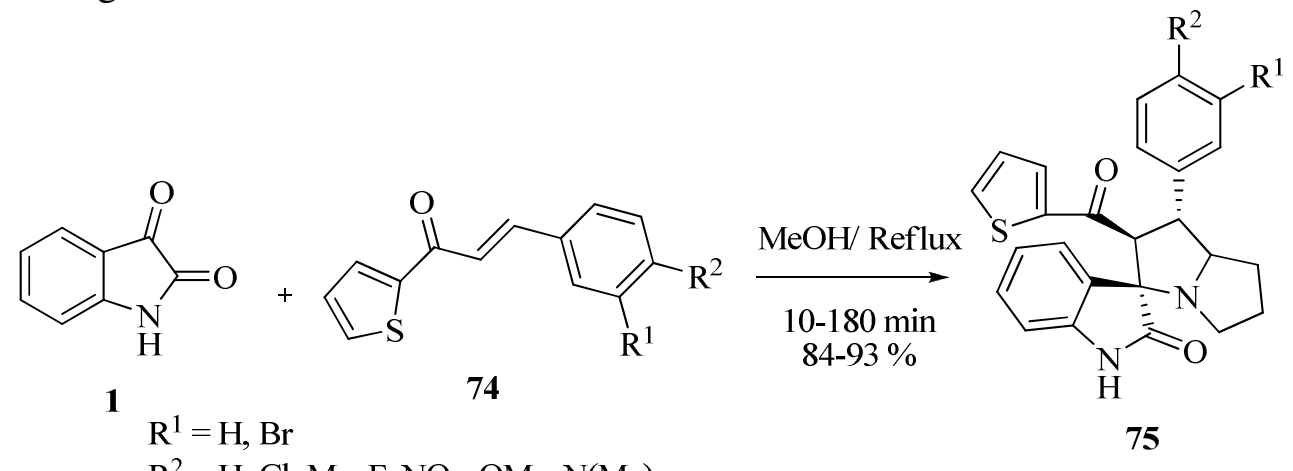

\section{Scheme 23}

Investigations by Pardasani and coworkers have shown that the oxazolidinone compound 78, was derived from the condensation of isatin with L-proline, while in the presence of a dipolarophile, the intermediate iminium species 76 underwent decarboxylation to give the azomethine ylide 79 which subsequently underwent 1,3-dipolar cycloaddition reactions to give spiro-polycyclic compounds $\mathbf{8 0}$ and $\mathbf{8 1}$ (Scheme 24). ${ }^{38}$ 


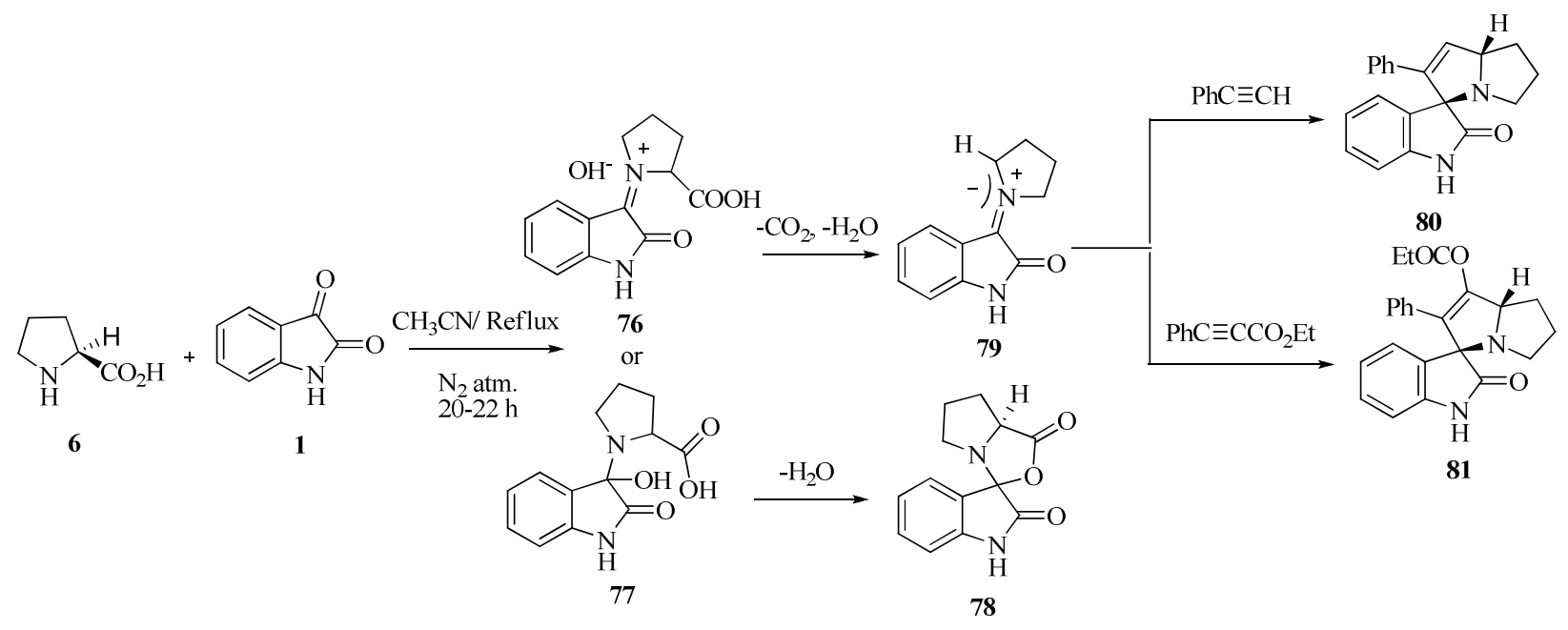

\section{Scheme 24}

3,5-Bis(arylmethylidene)- $N$-methyl-4-piperidinone $\mathbf{8 2}$ in reaction with isatin and benzyl amine yielded the desired product $\mathbf{8 4}$ that was subsequently reacted with a nitrile oxide generated in situ from 4-chlorobenzohydroximoyl chloride $\mathbf{8 5}$ and triethylamine, with a view to obtaining trispiro-compounds $\mathbf{8 6}$. However, this reaction furnished solely monospiroisoxazolines $\mathbf{8 7}$ in $45-$ $56 \%$ yields (Scheme 25$){ }^{39}$

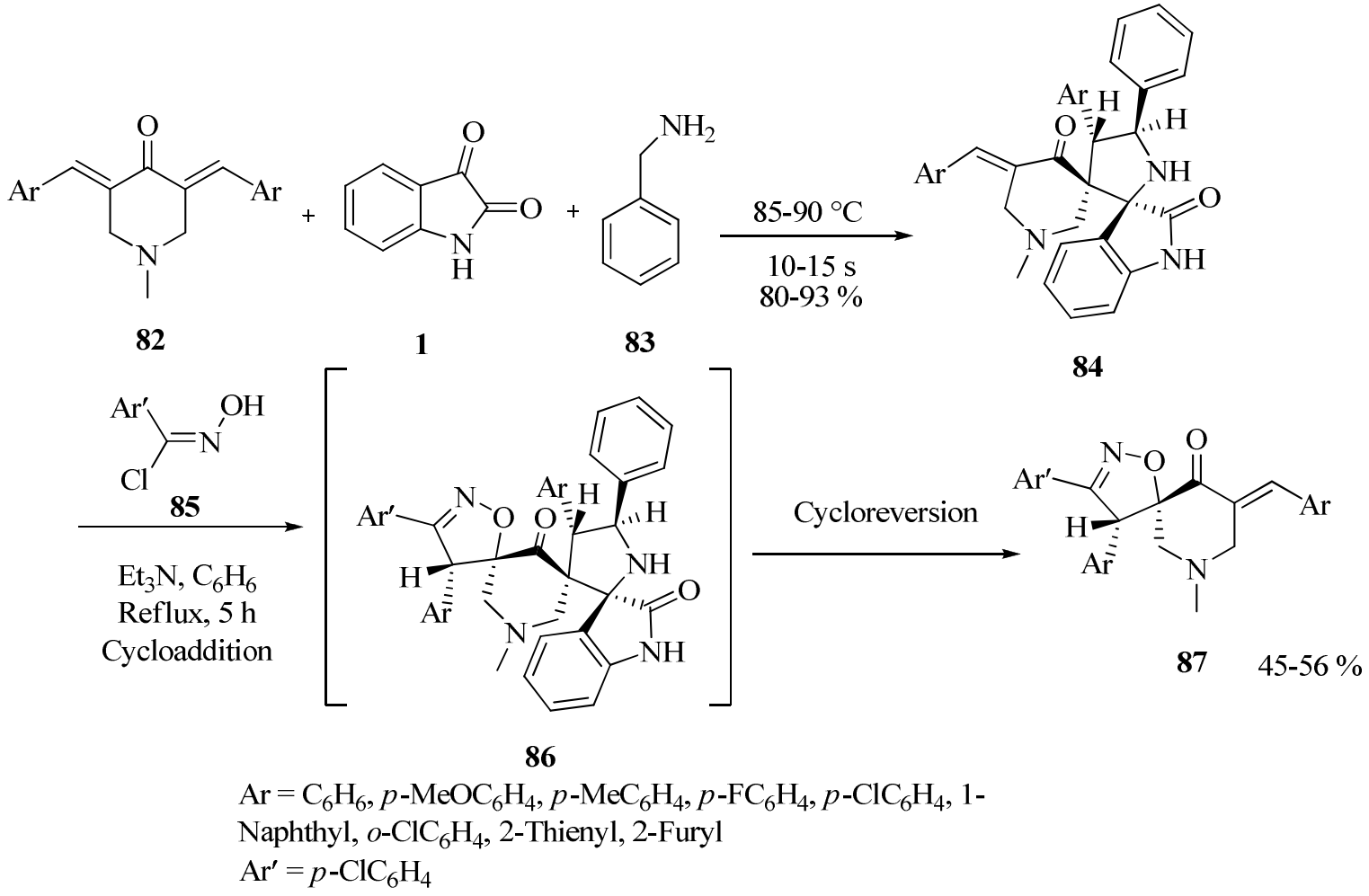

\section{Scheme 25}


The multicomponent reaction of isatin 1, 3-phenyl-5-isoxazolone 88, and sarcosine $\mathbf{1 7}$ or Lproline 6 in methanol under reflux has been reported (Scheme 26). ${ }^{40}$ The reaction proceeded through an unusual mechanistic pathway resulting in the synthesis of spirooxindole derivatives 89 and 90.

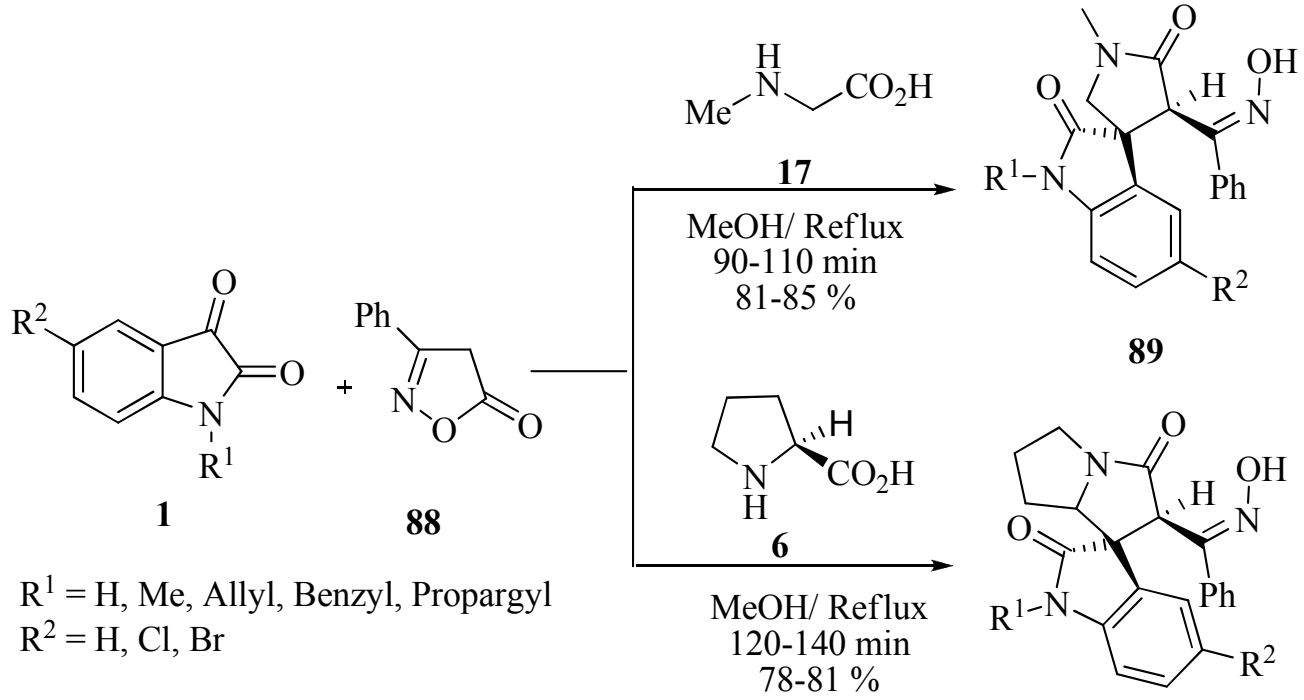

90

\section{Scheme 26}

Cascade thermal reactions of uracil polyoxin C (UPoC) 91 with isatin as a dicarbonyl compound in the presence of $N$-methylmaleimide (NMM) 92 leads, via an intermediate azomethine ylide, to polyoxin cycloadducts 93 and 94 in excellent yields (Scheme 27). ${ }^{41}$<smiles>CN1C(=O)C=CC1=O</smiles>

\section{Scheme 27}

The chemistry of phosphorus and sulfur ylides has been exploited for the reaction of various bromoallyl derivatives 95 with methyl acrylate, methyl vinyl ketone and $N$-phenylmaleimide 96 to afford the respective spirocyclic products $\mathbf{9 7}$ in good to moderate yields. The reaction of the bromoallyl derivatives of 1-methyl isatins 95 in acetonitrile with $\mathrm{Me}_{2} \mathrm{~S}$, diazo compounds 98 , and $\mathrm{K}_{2} \mathrm{CO}_{3}$ at room temperature afforded 3-spiropyrazole-2-oxindoles 99 (Scheme 28). ${ }^{42}$ 
<smiles>[Y]C(CBr)=C1C(=O)N([R])c2ccccc21</smiles>

95<smiles>[Z2]C=CCC(=O)OCc1ccccc1</smiles>

96<smiles>[Z]C1=CCC([Z])[C@]12C(=O)N([R])c1ccccc12</smiles>

97
$\mathrm{R}^{1}=\mathrm{Me}$, Benzyl, Propargyl

$\mathrm{R}^{2}=\mathrm{H}, \mathrm{Me}, \mathrm{CHO}, \mathrm{F}$

$\mathrm{Z}^{1}=\mathrm{CN}, \mathrm{CO}_{2} \mathrm{Me}$

$\mathrm{Z}^{2}=\mathrm{CO}_{2} \mathrm{Me}, \mathrm{COMe}, \mathrm{C}_{10} \mathrm{H}_{7} \mathrm{O}_{2} \mathrm{~N}$ $\mathrm{Z}^{3}=\mathrm{CO}_{2} \mathrm{Et}, \mathrm{CO}_{2} \mathrm{CHMe}_{2}, \mathrm{CO}_{2} \mathrm{CMe}_{3}$<smiles>[Y]N=N[Y]N=[Z]</smiles>

95<smiles>[Z]NN([Z])/C=C(/[3H])[C@@]1(C(=O)N([Z])[Y])C(=O)N([R])c2ccc(C)cc21</smiles>

99

\section{Scheme 28}

Regioisomeric spiro(indoline-isoxazolidines) 103 and 104 have been synthesized in moderate yields by the cycloaddition reaction between ethyl (3-indolylidene)acetate $\mathbf{1 0 1}$ and various substituted $\alpha, N$-diphenylnitrones 102, using microwave irradiation (Scheme 29). ${ }^{43}$

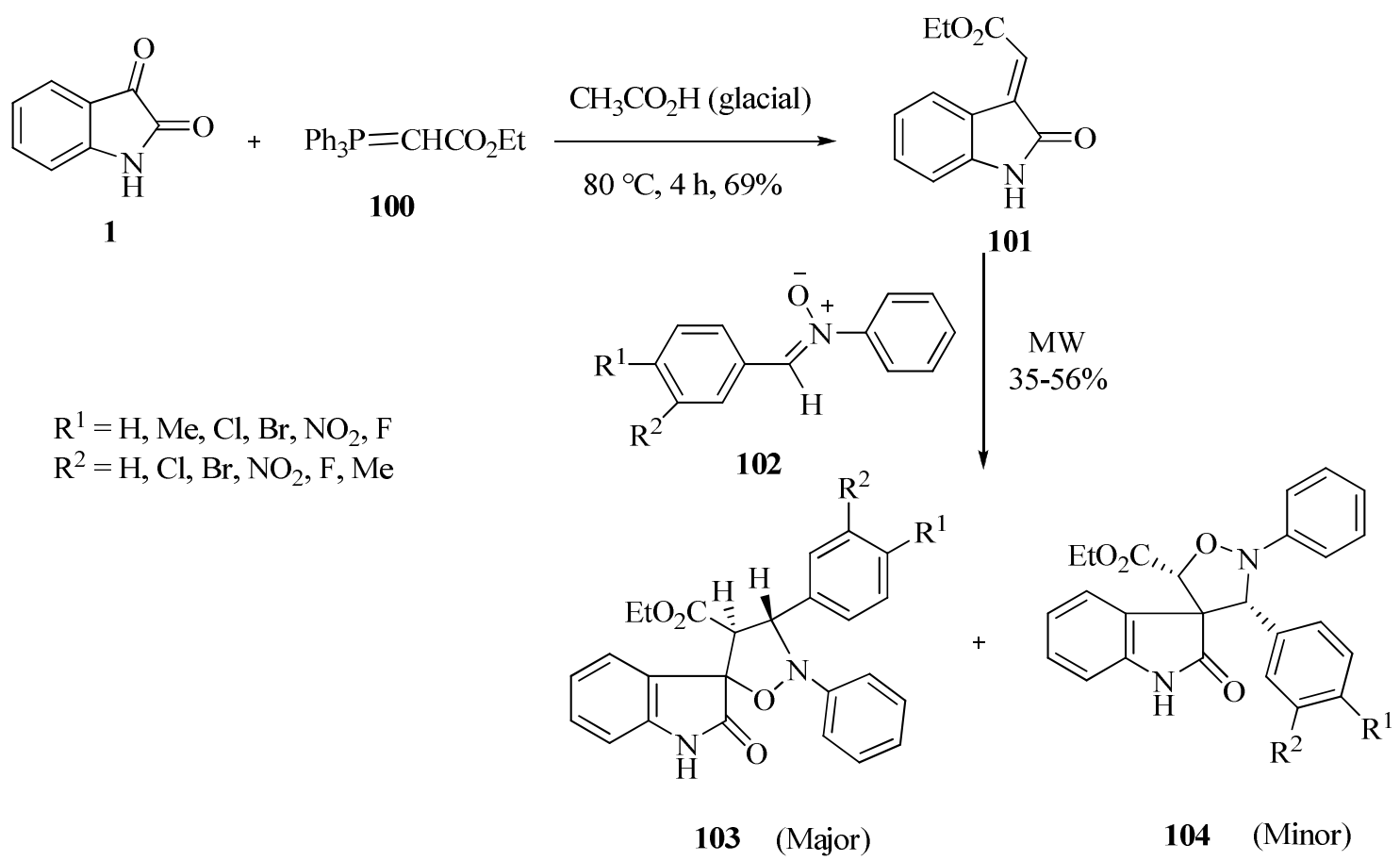

\section{Scheme 29}


The 1,3-dipolar cycloaddition of stable isatin ketonitrone $\mathbf{1 0 6}$ with various cyclic and acyclic dipolarophiles has been conducted under classical, ionic liquid and solvent-free conditions to give novel spiro[oxindole-isoxazolidine] derivatives 108 and 109 with similar diastereoselectivity (Scheme 30). ${ }^{44}$ Condensation of isatin $\mathbf{1}$ or isatin imine $\mathbf{1 0 5}$ with phenylhydroxylamine led to the formation of stable isatin ketonitrones $\mathbf{1 0 6}$ and $\mathbf{1 0 7}$ in high yields. It was found from ROESY and NOE investigations that the configuration of the stable isatin ketonitrone was $Z$ and not $E$.

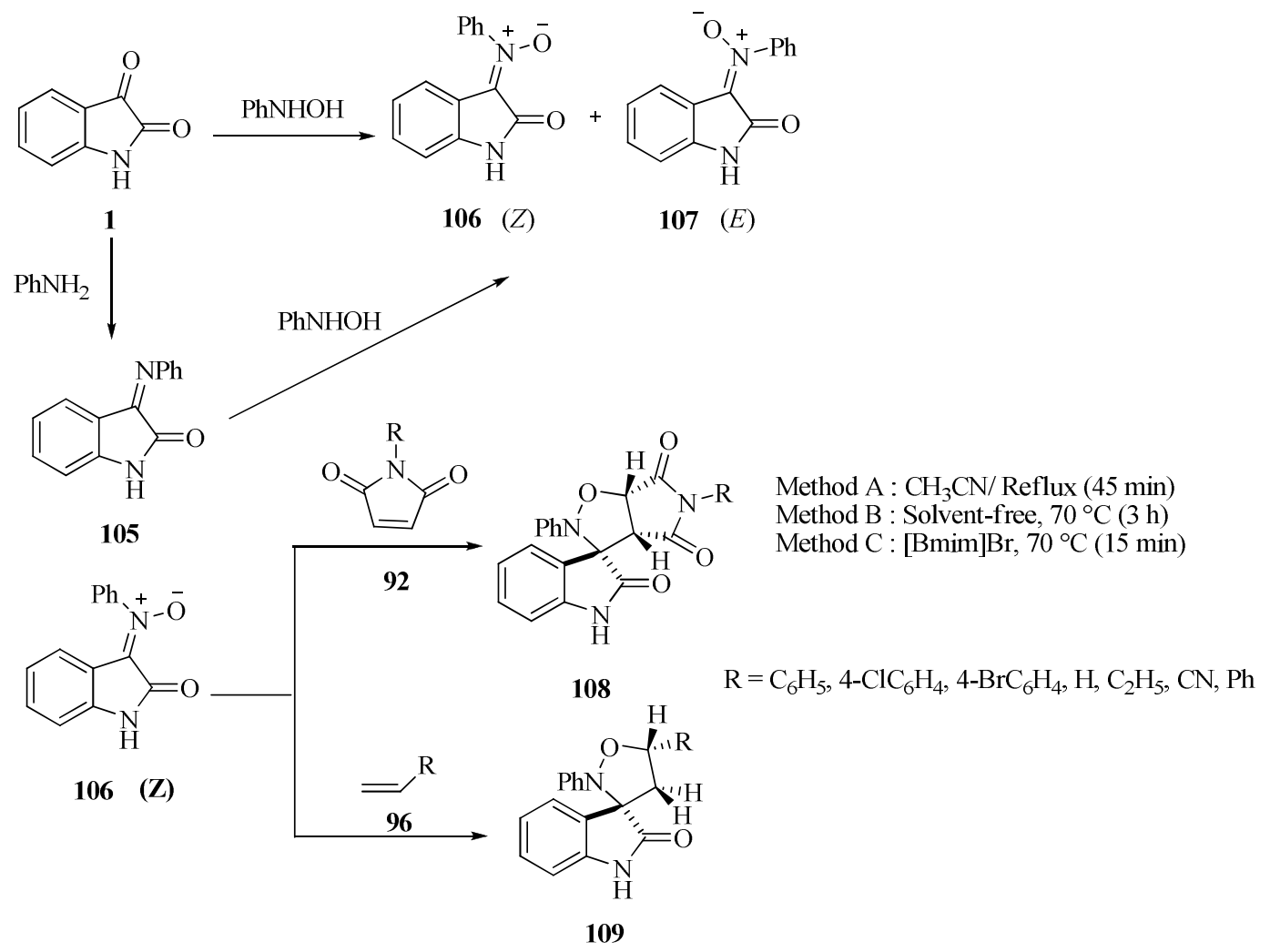

\section{Scheme 30}

The 1,3-dipolar cycloaddition reaction of isatin derivatives with the nitrile oxide generated in situ from 4-methoxybenzaldoxime $\mathbf{1 1 0}$ and sodium hypochlorite for synthesis of novel spiro[1,4,2-dioxazole-5,3'-indolin]-2'-one derivatives 111 and 112 was studied (Scheme 31). ${ }^{45}$ It was found that, besides the $\mathrm{C}=\mathrm{O}$ participating in the formation of the 1,4,2-dioxazole ring, the $\mathrm{C}$ $\mathrm{C}$ alkene (allyl) or alkyne (propargyl) bond also underwent 1,3-dipolar cycloaddition reaction with the nitrile oxide to form an isoxazole linked to the indole nitrogen by a methylene group. 
<smiles>[R]N1C(=O)C(=O)c2ccccc21</smiles>

$\mathrm{R}=\mathrm{H}$, Benzyl, Allyl, Propargyl<smiles>COc1ccc(/C=N/O)cc1</smiles>

$$
\begin{aligned}
& \mathrm{R}=\operatorname{Benzyl}(73 \%) \\
& \mathrm{R}=\operatorname{Allyl}(47 \%) \\
& \mathrm{R}=\operatorname{Propargyl}(54 \%)
\end{aligned}
$$$$
\mathrm{R}=\mathrm{H}(76 \%)
$$

112

\section{Scheme 31}

Condensation of methyl 4-acetylphenylcarbamate $\mathbf{1 1 3}$ with isatin afforded $\mathbf{1 1 4}$ which was converted into the corresponding chalcone 115. 1,3-Dipolar cycloaddition to that chalcone of the azomethine ylide generated from 2-phenacylisoquinolinium bromide $\mathbf{1 1 6}$ by the action of triethylamine gave 117 (Scheme 32). ${ }^{46}$
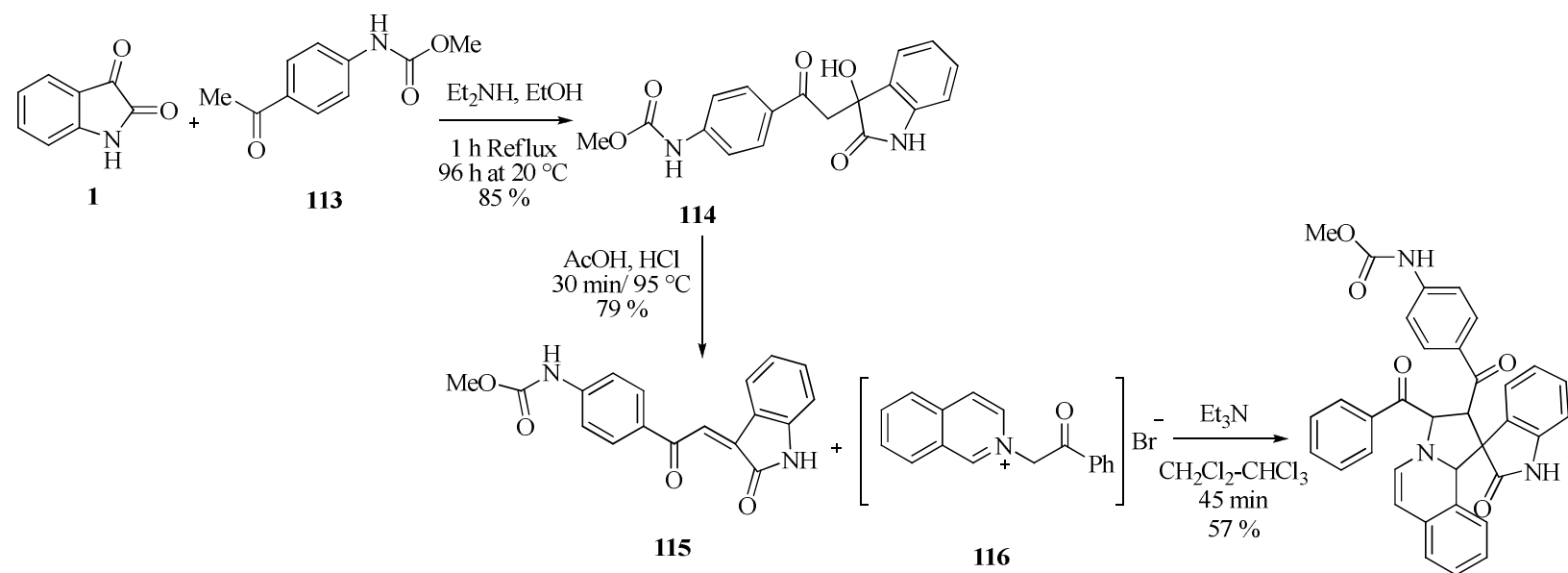

117

\section{Scheme 32}

Spiroindoles 121 were prepared readily via a one-pot, 1,3-dipolar cycloaddition reaction of azomethine imines 120 with isatin imines 105 under microwave irradiation and classical heating (Scheme 33). ${ }^{47}$ By using microwave irradiation, the reaction time was reduced greatly from 9-14 hours to $6-8 \mathrm{~min}$ and the yield of the reaction was enhanced by $10-20 \%$ compared to the conventional heating method. 


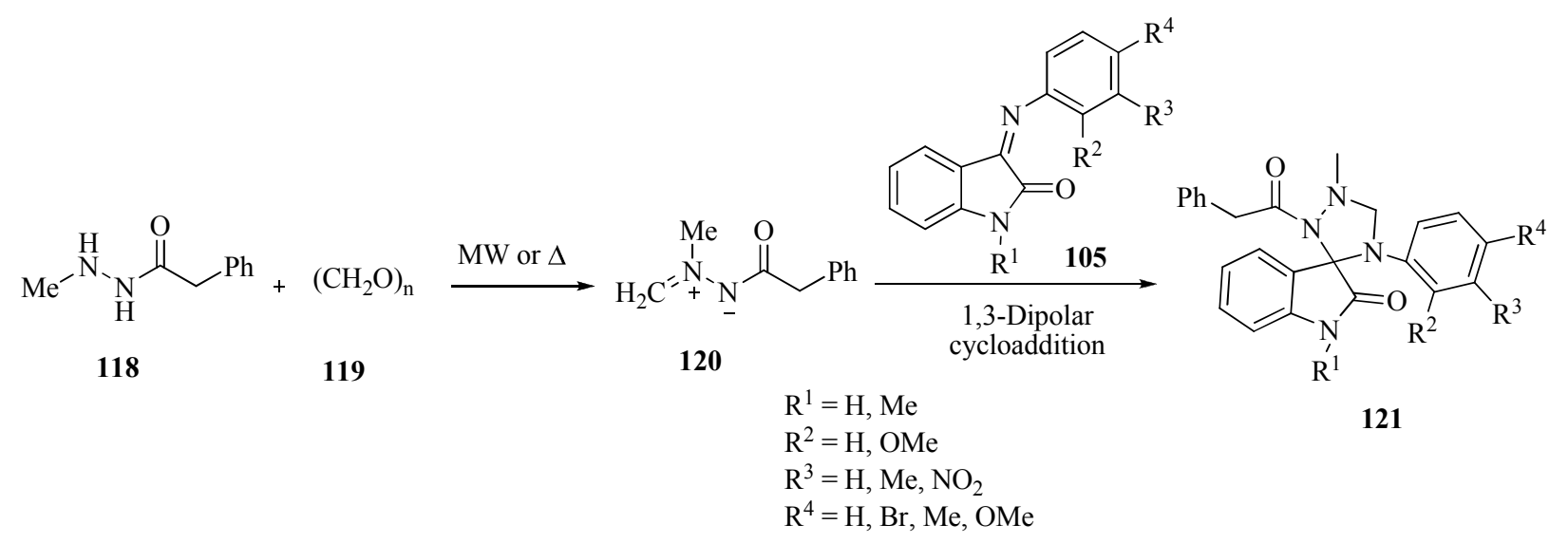

\section{Scheme 33}

The combination of an $\alpha$-diazoester 123 and an imine 122 in the presence of a $\mathrm{Cu}(\mathrm{I})$ catalyst generated a transient azomethine ylide which underwent a highly diastereoselective cycloaddition with dipolarophile $\mathbf{1 2 4}$ to afford highly substituted spiropyrrolidinyloxindoles $\mathbf{1 2 5}$ in a convergent, three-component assembly reaction (Scheme 34$){ }^{48}$

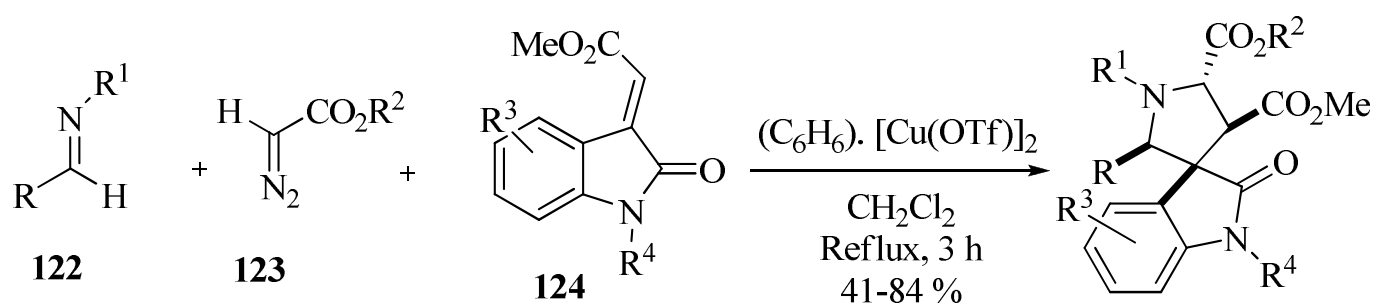

$\mathrm{R}=\mathrm{Ph}, 4-\mathrm{MeC}_{6} \mathrm{H}_{4}, 4-\mathrm{ClC}_{6} \mathrm{H}_{4}, 4-\mathrm{BrC}_{6} \mathrm{H}_{4}, 4-\mathrm{OMeC}_{6} \mathrm{H}_{4}, 2-\mathrm{ClC}_{6} \mathrm{H}_{4}$, 2-thiophenyl

$\mathrm{R}^{1}=\mathrm{Ph}, 4-\mathrm{ClC}_{6} \mathrm{H}_{4}, 3-\mathrm{FC}_{6} \mathrm{H}_{4}$

$\mathrm{R}^{2}=\mathrm{Et}, t-\mathrm{Bu}$

$\mathrm{R}^{3}=\mathrm{H}, 5^{\prime}-\mathrm{Cl}$

$\mathrm{R}^{4}=\mathrm{Bn}, \mathrm{Me}, \mathrm{Ac}$

\section{Scheme 34}

$\alpha$-Diazo ketones 126 or 127 and isatin in the presence of 1 mol\% of $\mathrm{Rh}_{2}(\mathrm{OAc})_{4}$ led to novel spiro dioxa-bridged indole derivatives as a mixture of diastereomers (Scheme 35$){ }^{49}$ 


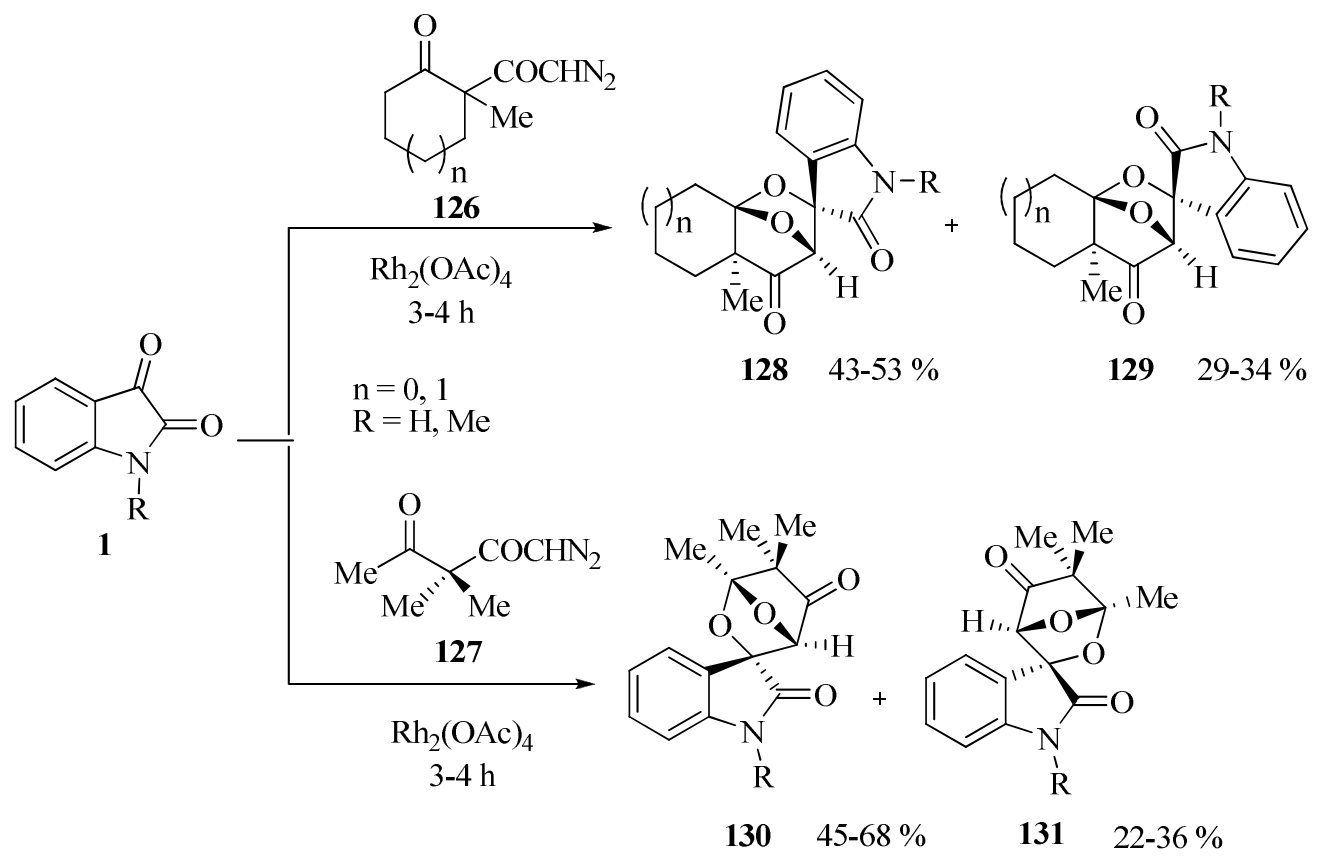

\section{Scheme 35}

Treatment of isatin with 5-aminoindazole 132 and mercaptoacetic acid provided the desired spiro systems containing three heterocyclic moieties namely indole, thiazolidine, and indazole 134 (Scheme 36). ${ }^{50}$

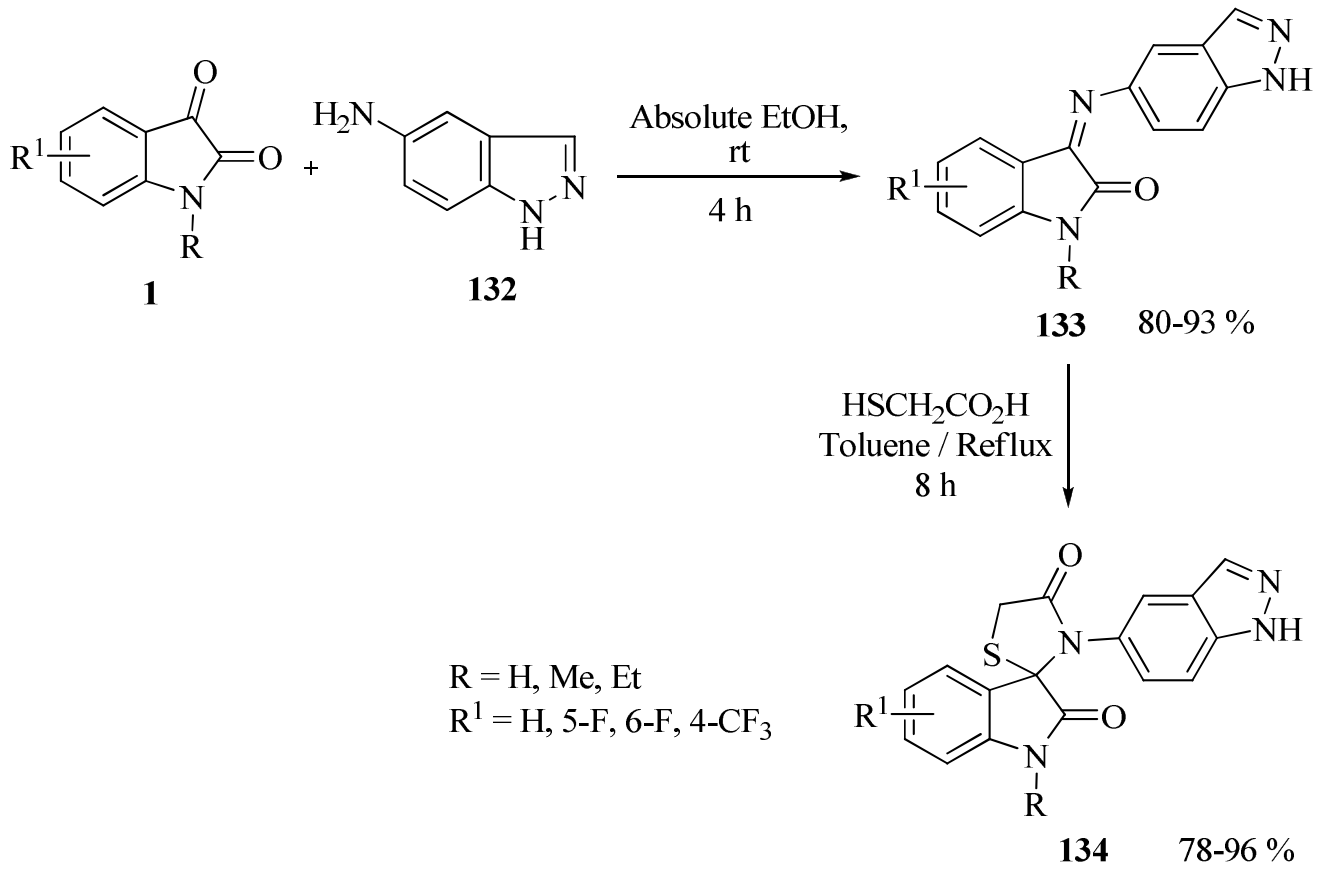

\section{Scheme 36}


1,3-Dipolar cycloaddition of ylides generated in situ by the decarboxylative condensation of isatin with 1,3-thiazolane-4-carboxylic acid $\mathbf{1 3 5}$ with ethyl phenyl propiolate $\mathbf{1 3 7}$ or methyl acrylate $\mathbf{1 3 6}$ led to novel spiro compounds $\mathbf{1 3 8}$ or 139, respectively (Scheme 37). ${ }^{51}$

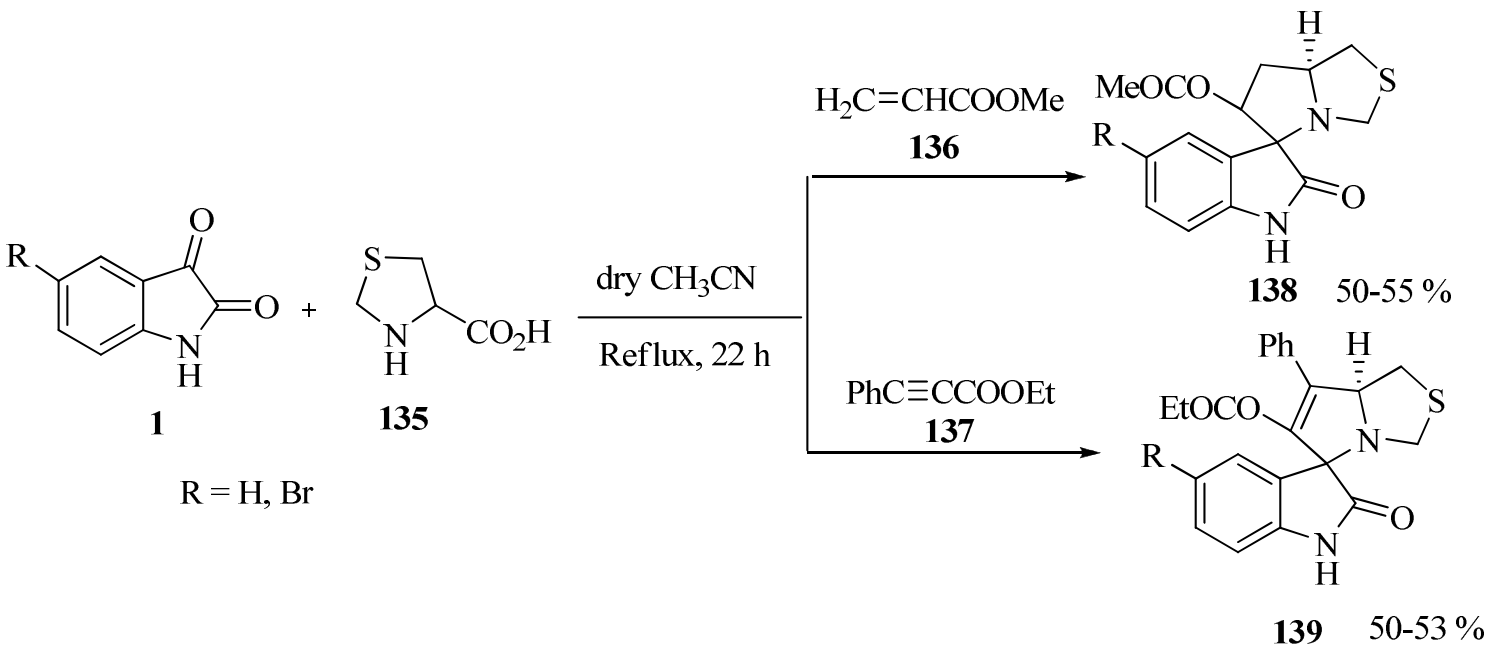

\section{Scheme 37}

\section{Synthesis of Dispiropyrrolo/pyrrolizidino-oxindole Ring Systems}

An efficient synthesis of novel dispiroheterocycles containing the oxindole ring has been accomplished by 1,3-dipolar cycloaddition reaction of azomethine ylides generated by the decarboxylative route from tetrahydroisoquinoline-3-carboxylic acid $\mathbf{1 4 0}$ and isatin with unusual dipolarophiles such as 3-arylidene-4-chromanone 141, 3-arylidene-4-flavanone 142 and 2-arylidenetetrahydro-1-naphthalenone $\mathbf{1 4 3}$ (Scheme 38). ${ }^{52}$ 


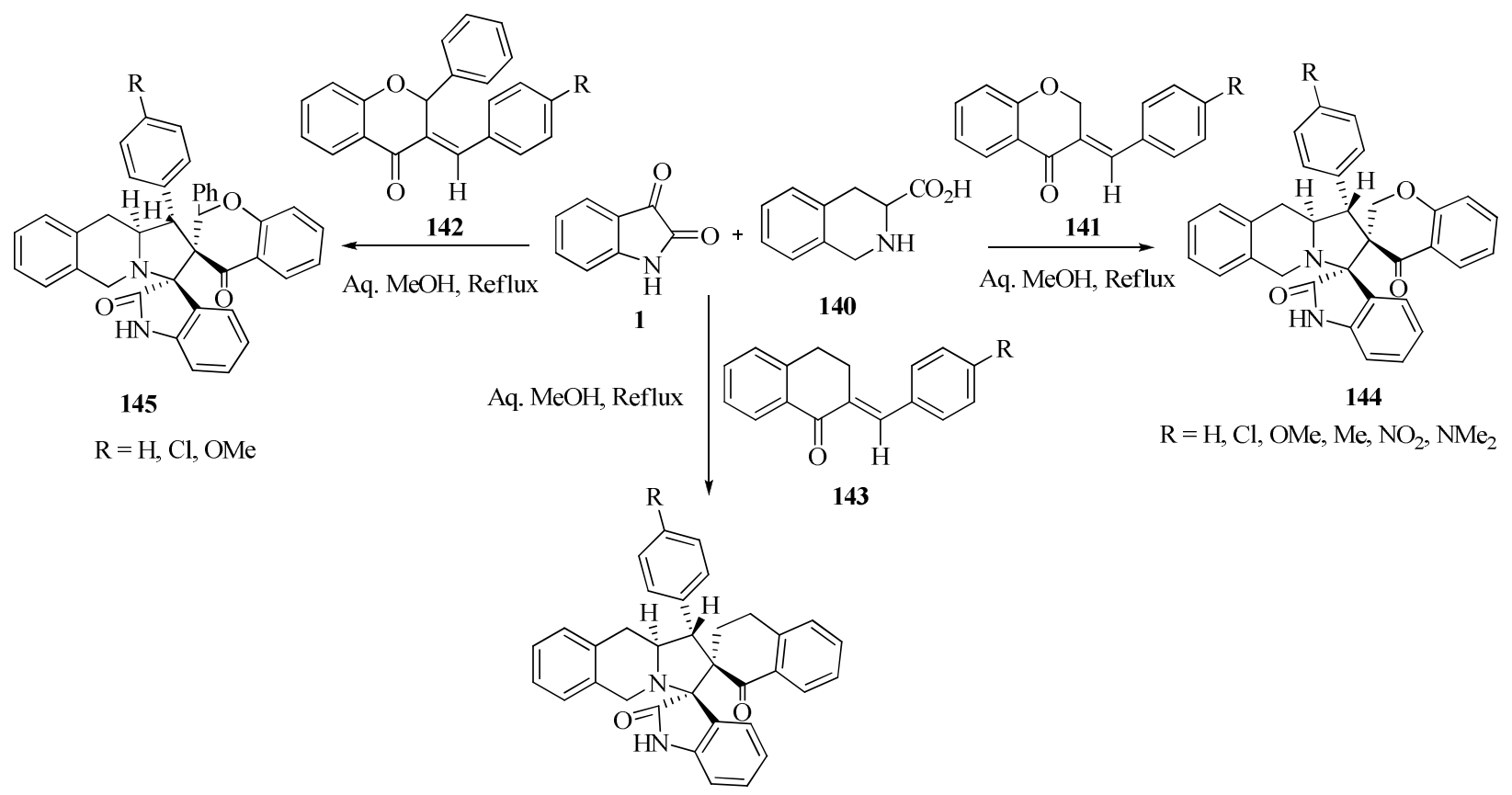

$146 \mathrm{R}=\mathrm{H}, \mathrm{Cl}, \mathrm{OMe}, \mathrm{Me}$

\section{Scheme 38}

Similarly, the secondary amines morpholine $\mathbf{1 4 7}^{53}$ and sarcosine 17 (Scheme 39), ${ }^{54}$ were used in the above reaction.<smiles>[R]c1ccc(C2C3COCCN3C3(C(=O)Nc4ccccc43)C23CCc2ccccc2C3=O)cc1</smiles>

149<smiles>[R]c1ccc(/C=C2\CCc3ccccc3C2=O)cc1</smiles>

143

Dry $\mathrm{CH}_{3} \mathrm{CN}$ Reflux

1
147

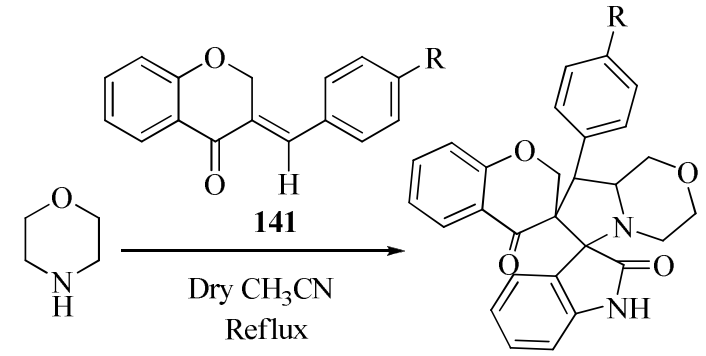

148

$\mathrm{R}=\mathrm{H}, \mathrm{Me}, \mathrm{OMe}, \mathrm{Cl}, \mathrm{NO}_{2}$<smiles>CNCC(=O)OCc1ccccc1/C=C1\CCc2ccccc2C1=O</smiles>

17

143

$\mathrm{R}=p-\mathrm{H}, p-\mathrm{Me}, p-\mathrm{Cl}, p-\mathrm{N}(\mathrm{Me})_{2}, m-\mathrm{NO}_{2}$

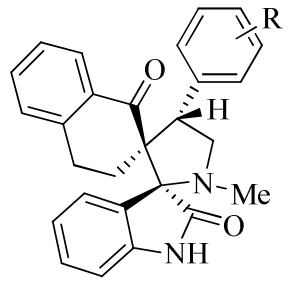

150

\section{Scheme 39}


Use of (E)-2-benzylidene-1-cyclohexanones 151 as dipolarophiles was also described, leading to the formation of novel dispiro[oxindole-cyclohexanone]pyrrolidines $\mathbf{1 5 2},{ }^{55}$ and dispiro[oxindole-cyclohexanone]pyrroloisoquinolines 153 (Scheme 40). ${ }^{56}$

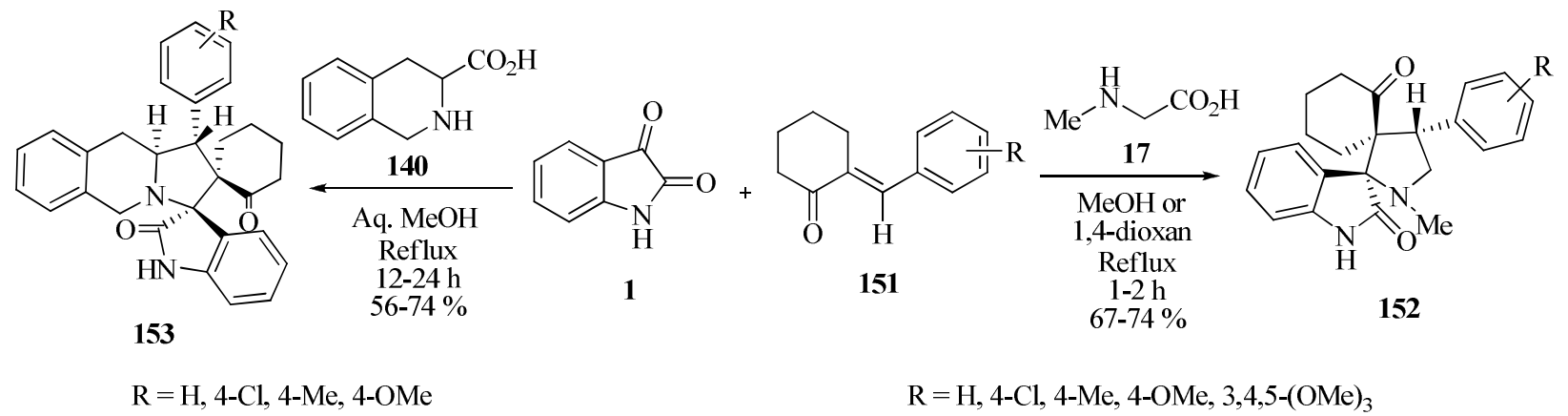

\section{Scheme 40}

Reaction of azomethine ylide generated from proline and isatin with the dipolarophile $(E)$-2arylidine-1-ketocarbazoles $\mathbf{1 5 4}$ resulted in the formation of dispirooxindolopyrrolizidine derivatives 155 that possessed antibacterial and antifungal activities (Scheme 41). ${ }^{57}$

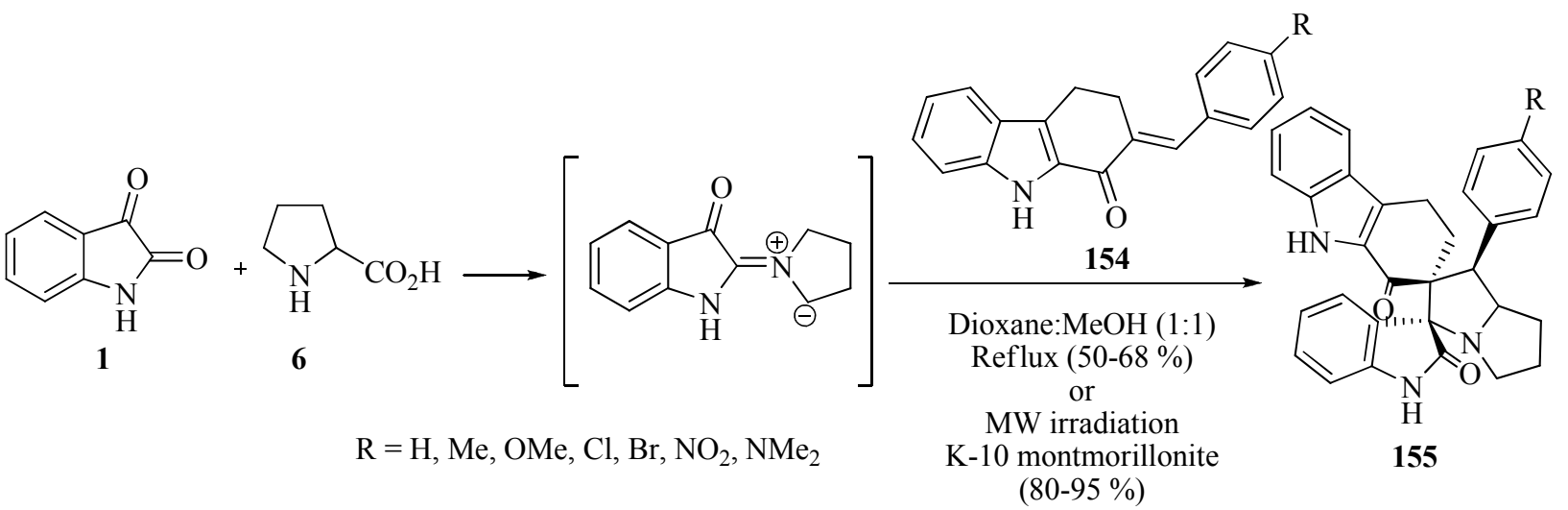

\section{Scheme 41}

In another study, the dipolarophiles, $(E)$-2-(arylmethylidene)-3,4-dihydro-1(2H)-acridinones 157, prepared by the base-catalyzed condensation of 3,4-dihydroacridin-1(2H)-one 156 with substituted benzaldehydes, readily reacted with nonstabilized azomethine ylides, to afford dispirooxindolyl-[acridine-2',3-pyrrolidine]-10-ones 158 (Scheme 42). ${ }^{58}$ 


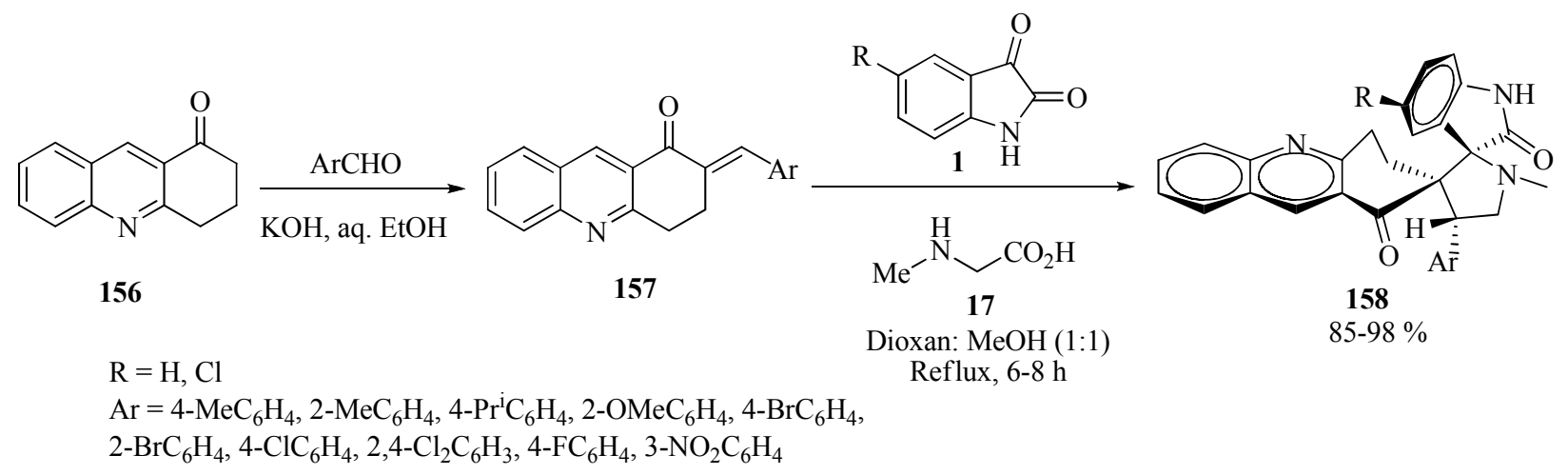

\section{Scheme 42}

A class of novel tetracyclic dispiropyrrolizidines $\mathbf{1 6 0}$ has been synthesized via the 1,3-dipolar cycloaddition of azomethine ylide with dipolarophiles 159 under conventional heating and ultrasound irradiation conditions (Scheme 43). ${ }^{59}$

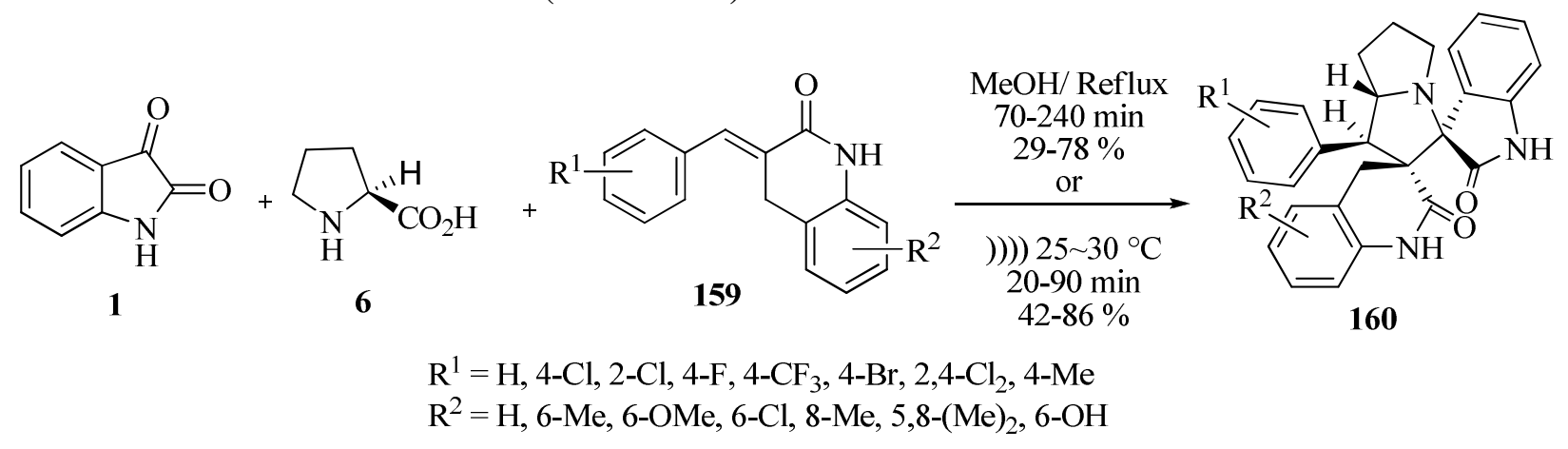

\section{Scheme 43}

Arylidene cycloheptanones and arylidene cyclooctanones 161 were used as dipolarophiles. It was observed that the isatin/sarcosine derived nonstabilized azomethine ylide added regioselectively across the exocyclic double bonds of the dipolarophiles to give novel spiroheterocycles 162 (Scheme 44). ${ }^{60}$

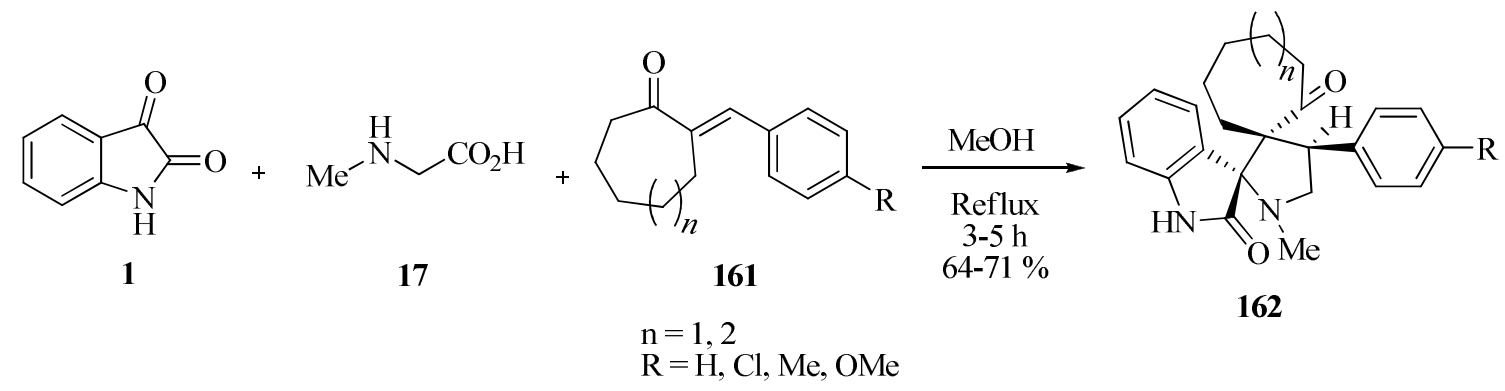

\section{Scheme 44}


Synthesis of novel dispiro pyrrolo/pyrrolizidino ring systems by the cycloaddition of azomethine ylides with the dipolarophile 9-arylidine-fluorene 163 using four different methodologies has been described (Scheme 45). ${ }^{61}$ A solvent-free microwave-assisted approach gave products with the highest yields in the shortest times.

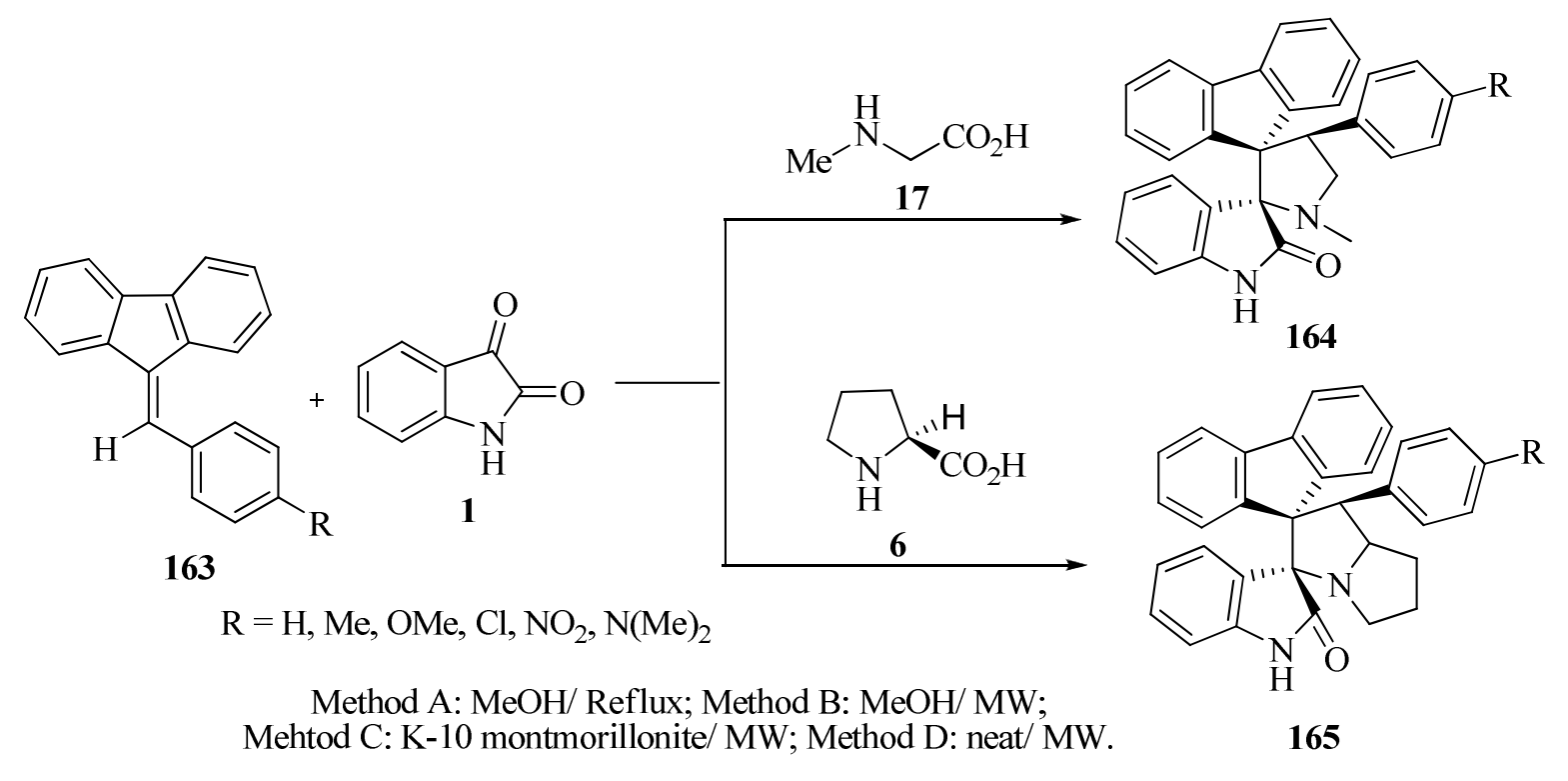

\section{Scheme 45}

Application of 2-oxo-(2H)-acenaphthylen-1-ylidene-malononitrile Knoevenagel adducts 166, as dipolarophiles in 1,3-dipolar cycloaddition reaction of azomethine ylides has been studied. Under similar conditions, 2-fluoren-9-ylidene-malononitrile $\mathbf{1 6 7}$ has been applied to furnish the respective dispiropyrrolidine oxindole derivatives (Scheme 46 ). ${ }^{62}$

The synthesis of novel dispiropyrrolidine bisoxindole derivatives 172 via condensation of azomethine ylides with the Knoevenagel adduct 56, prepared by the reaction of isatins with malononitrile, was reported (Scheme 47). ${ }^{63}$ The pseudo-four-component reaction of isatin, malononitrile $\mathbf{1 7 0}$ and sarcosine afforded dispiropyrrolidine bisoxindoles containing two different indole rings 171. 


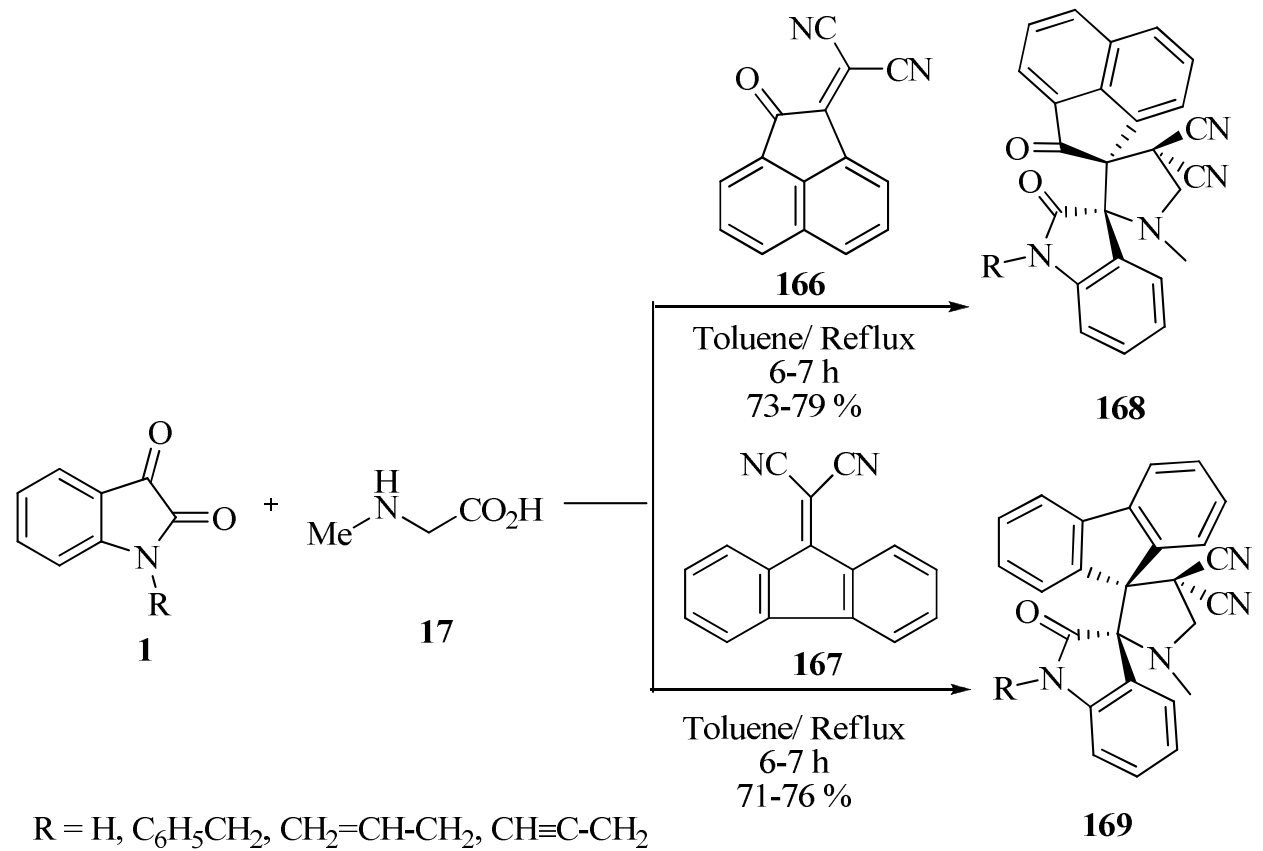

\section{Scheme 46}<smiles>[R]c1ccc2c(c1)C(=O)C(=O)N2[R]</smiles><smiles>N#CC[Na]</smiles><smiles>CNCC(=O)C(C)OC</smiles>
17 $\mathrm{R}^{1}=\mathrm{H}, \mathrm{Me}, \mathrm{F}, \mathrm{Cl}, \mathrm{Br}$ $\mathrm{R}^{2}=\mathrm{H}, \mathrm{Me}$<smiles>[R]c1ccc2c(c1)C(=O)C(=O)N2[Y]</smiles>

$\mathrm{R}^{1}=\mathrm{H}, \mathrm{Br}$<smiles>CNCC(=O)O</smiles>
17

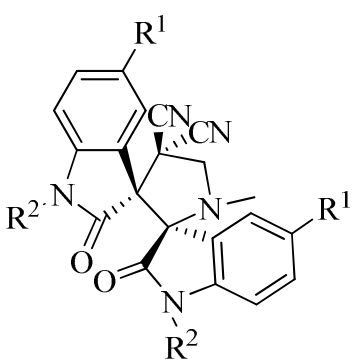

$\mathrm{R}^{2}=\mathrm{H}$

$\mathrm{R}^{3}=\mathrm{H}, \mathrm{Me}, \mathrm{F}, \mathrm{Cl}$

$\mathrm{R}^{4}=\mathrm{H}, \mathrm{Me}$

\section{Scheme 47}

Perumal and coworkers employed two dipolarophiles 173 and 174 to yield 175 and 176 respectively, as single products with good yields (Scheme 48). ${ }^{64}$ 


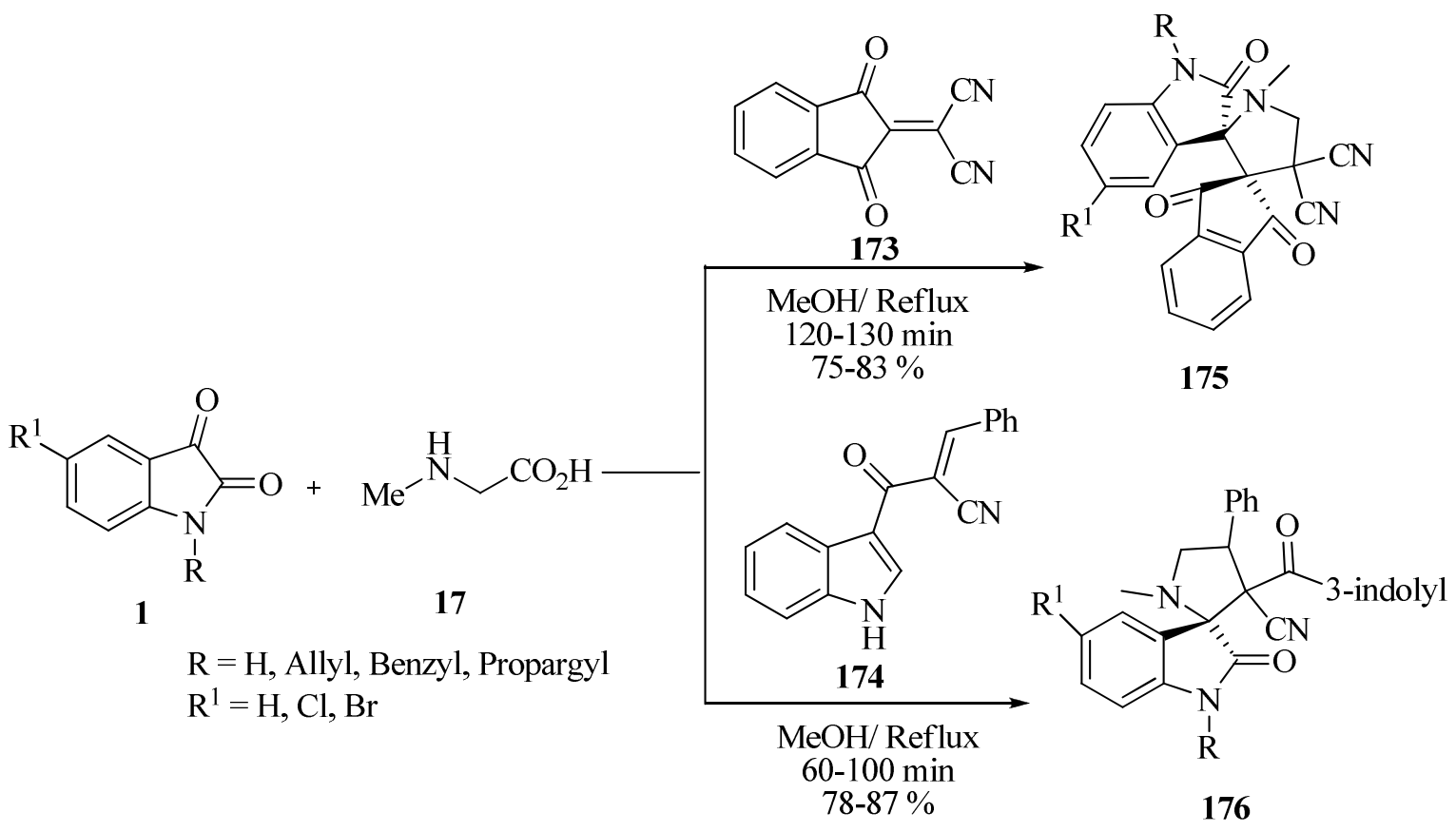

\section{Scheme 48}

Novel dispiropyrrolidines 179 were synthesized by a tandem Knoevenagel-1,3-dipolar cycloaddition reaction sequence of isatin, sarcosine, 1,3-indanedione 177, and an aldehyde 178 in the absence of catalyst (Scheme 49). ${ }^{65}$ Ethanol as the solvent, and a mol ratio of $1: 1.2: 1.2: 1$, were deemed to be the optimum reaction conditions.<smiles>O=C1Nc2ccccc2C1=O</smiles>

1<smiles>CNCC(=O)O</smiles>

17<smiles>O=C1CC(=O)c2ccccc21</smiles>

177<smiles>[R]C=O</smiles>

178<smiles>[R]C12c3ccccc3C(=O)[C@]1([R])[C@@]13C(=O)N(C)[C@@]21C(=O)Nc1ccccc13</smiles>

179

$\mathrm{R}=\mathrm{C}_{6} \mathrm{H}_{5}, 4-\mathrm{ClC}_{6} \mathrm{H}_{4}, 4-\mathrm{BrC}_{6} \mathrm{H}_{4}, 4-\mathrm{OHC}_{6} \mathrm{H}_{4}, 4-\mathrm{MeC}_{6} \mathrm{H}_{4}, 4-\mathrm{OMeC}_{6} \mathrm{H}_{4}, 3-\mathrm{NO}_{2} \mathrm{C}_{6} \mathrm{H}_{4}$,

$3-\mathrm{FC}_{6} \mathrm{H}_{4}, 3-\mathrm{OHC}_{6} \mathrm{H}_{4}, 3,4-(\mathrm{OMe})_{2} \mathrm{C}_{6} \mathrm{H}_{3}, 2-\mathrm{ClC}_{6} \mathrm{H}_{4}, 2-\mathrm{FC}_{6} \mathrm{H}_{4}, \mathrm{MeCH}_{2} \mathrm{CH}_{2}$

\section{Scheme 49}

2-Arylidene-1,3-indanediones $\mathbf{1 8 0}$ undergo regioselective 1,3-dipolar cycloaddition reaction with the azomethine ylide, affording a series of dispiro[oxindole/indanedione]pyrrolidine ring systems 181 (Scheme 50). ${ }^{66}$ 


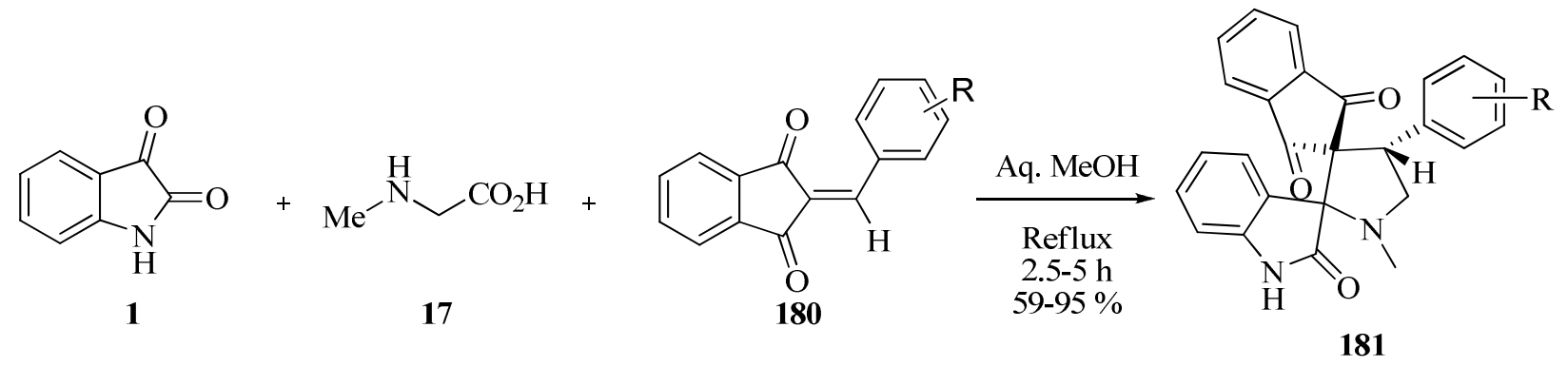

$\mathrm{R}=\mathrm{H}, p$-Cl, $p$-Me, $p$-OMe, $p$ - $\mathrm{NO}_{2}, m-\mathrm{Cl}, m-\mathrm{NO}_{2}, o-\mathrm{Cl}, o-\mathrm{NO}_{2}, 3^{\prime}, 4^{\prime}-\mathrm{OMe}, 3^{\prime}, 4^{\prime}, 5^{\prime}-\mathrm{OMe}$

\section{Scheme 50}

The reaction of tetrahydroisoquinoline-3-carboxylic acid 140 with 180 and isatin was reported, too. Compound $\mathbf{1 8 2}$ as an alternative dipolarophile, reacted with isatin and $\mathbf{1 4 0}$ in the presence of $\mathrm{TiO}_{2}-$ silica catalyst (Scheme 51). ${ }^{67}$

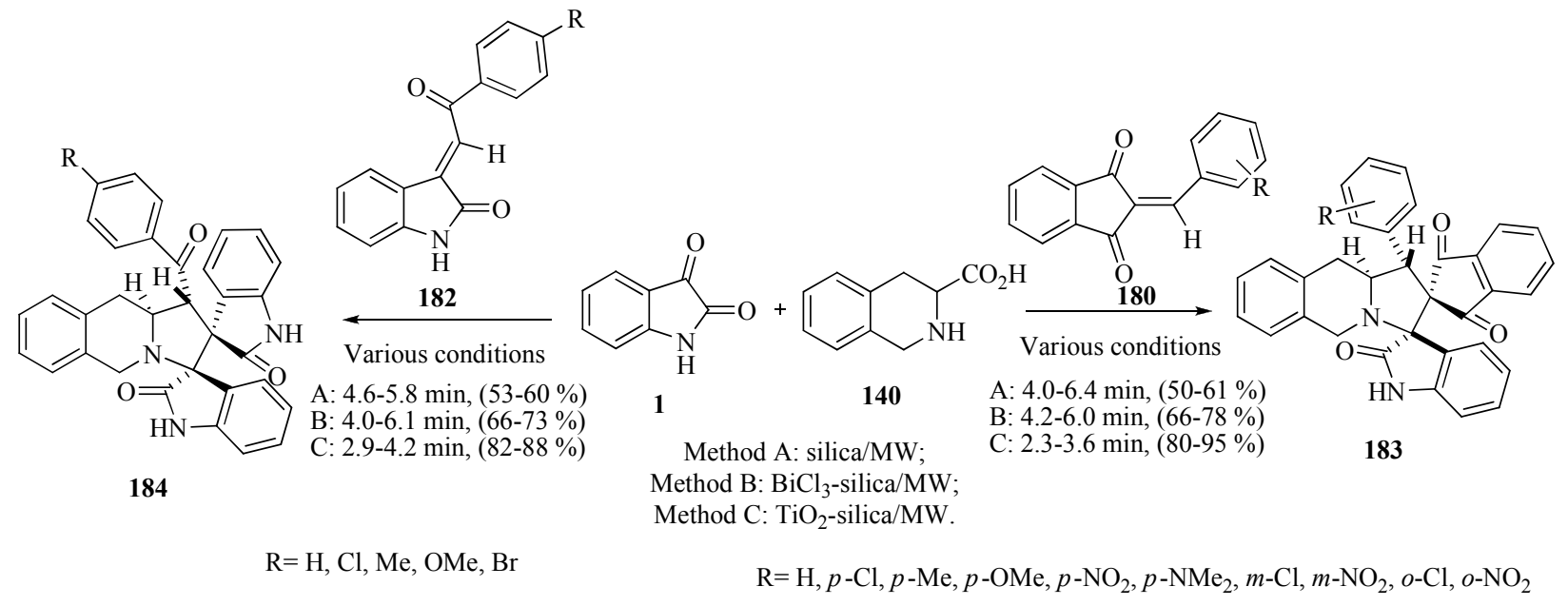

\section{Scheme 51}

Using 3,5-bis(arylmethylidene)- $N$-methyl-4-piperidinone 82, in refluxing methanol, the synthesis of novel spiropyrrolidinyl oxindole derivatives $\mathbf{1 8 5}$ has been investigated. Subsequent reaction with hydrazine hydrate afforded annulated products 186 (Scheme 52). ${ }^{68}$ 


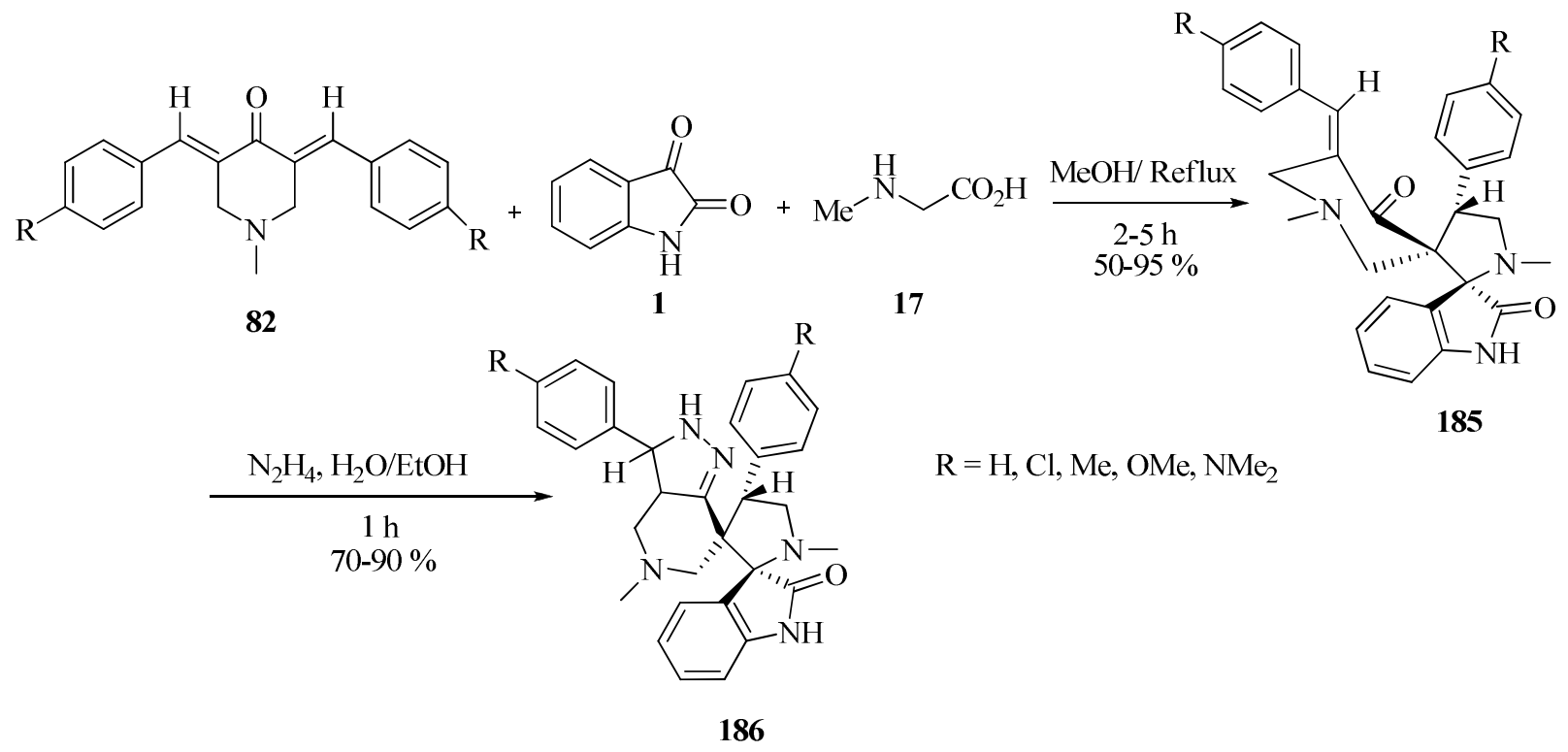

\section{Scheme 52}

Reaction of azomethine ylides with various $p$-substituted 2,6-bis(arylmethylidene)cyclohexanones 187 under different conditions, proceeded regioselectively to give novel dispiroheterocycles 188. The products, on subsequent annulation with hydrazine hydrate, afforded 189 in good yields (Scheme 53). ${ }^{69}$ Replacing benzylamine with sarcosine in this reaction has also been reported. ${ }^{70}$ The products were screened for their antibacterial and antifungal activity against ten human pathogenic bacteria and four dermatophytic fungi. ${ }^{6 a}$

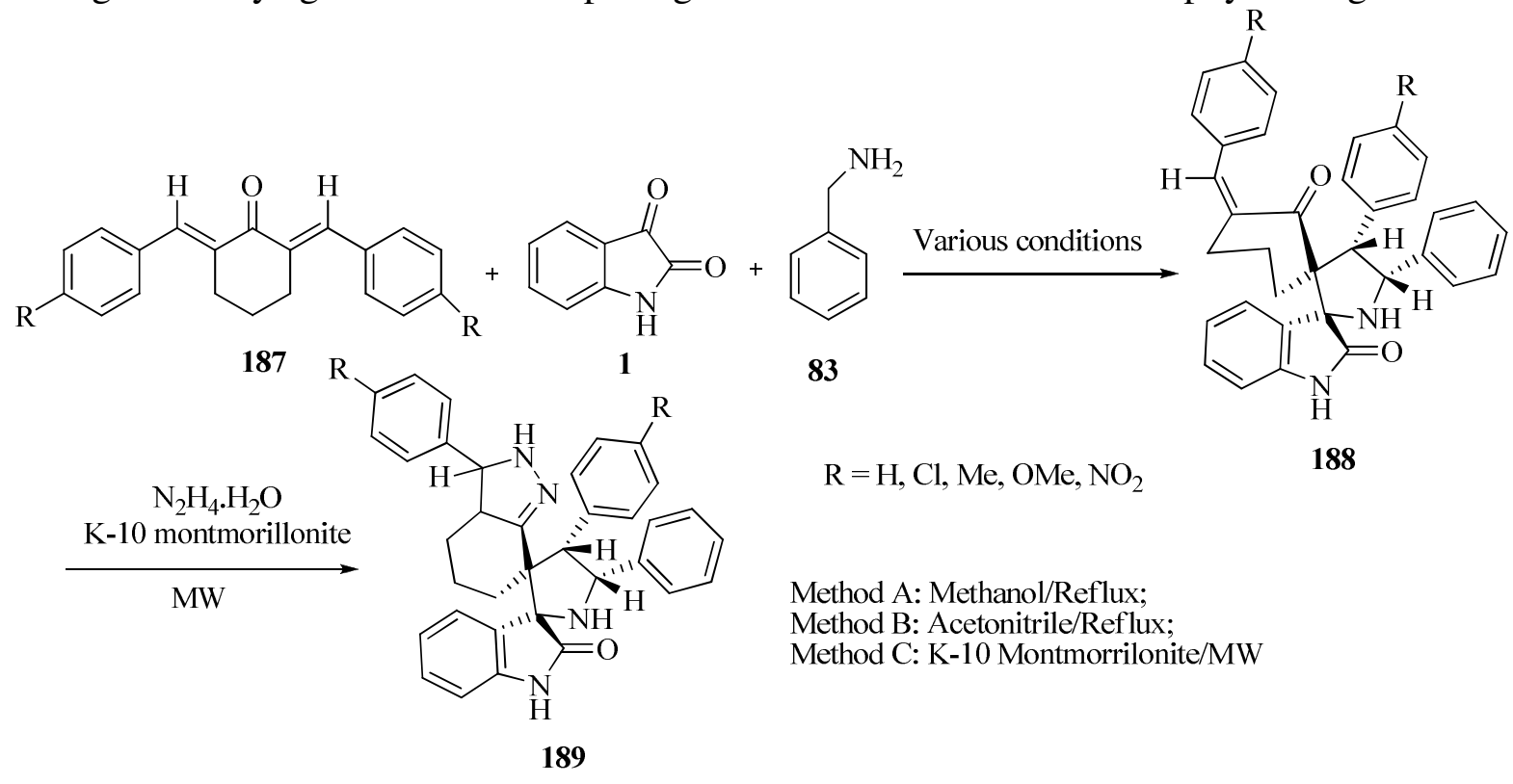

\section{Scheme 53}


(Z)-16-arylidene-estrone derivatives $\mathbf{1 9 0}$ as $2 \pi$ components were used in reactions with azomethine ylides for the synthesis of hitherto unknown steroidal dispiropyrrolidines 191 (Scheme 54). ${ }^{71}$ The reactions were carried out using three different sets of conditions.

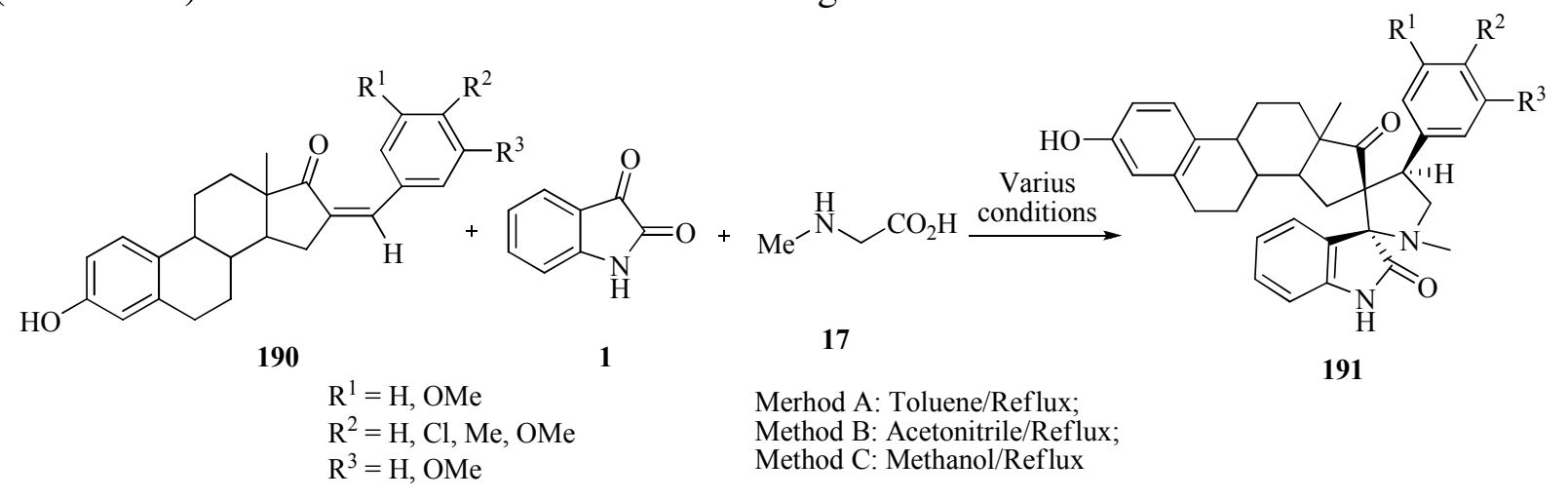

\section{Scheme 54}

El-Ahl used 143, 187, and 36 as dipolarophiles in the reaction with isatin-derived azomethine ylides (Scheme 55). ${ }^{72}$

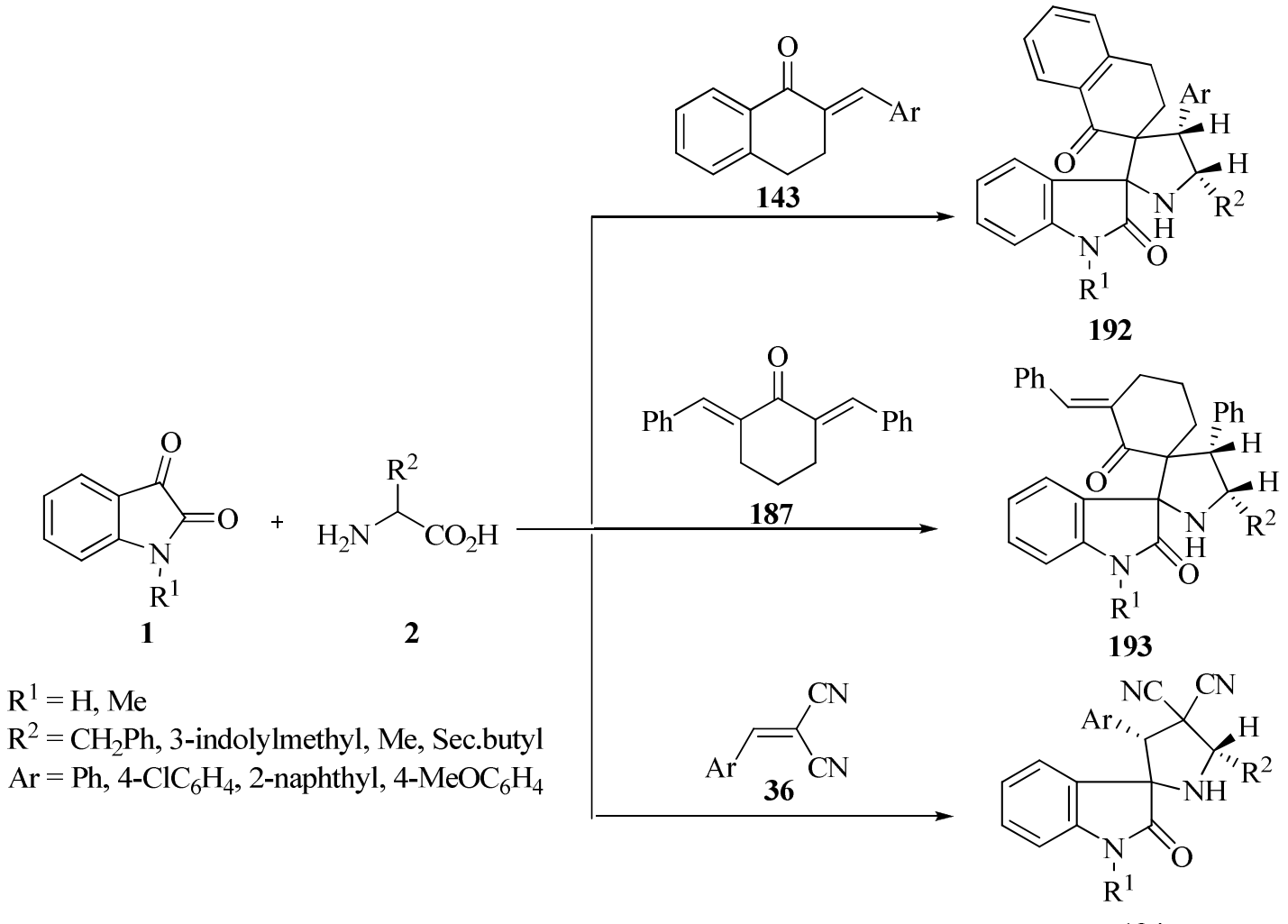

194

\section{Scheme 55}


1,3-Dipolar cycloaddition of azomethine ylides to the conjugated double bond of andrographolide 195 yielded adducts of andrographolide 196 and 197 (Scheme 56). ${ }^{73}$

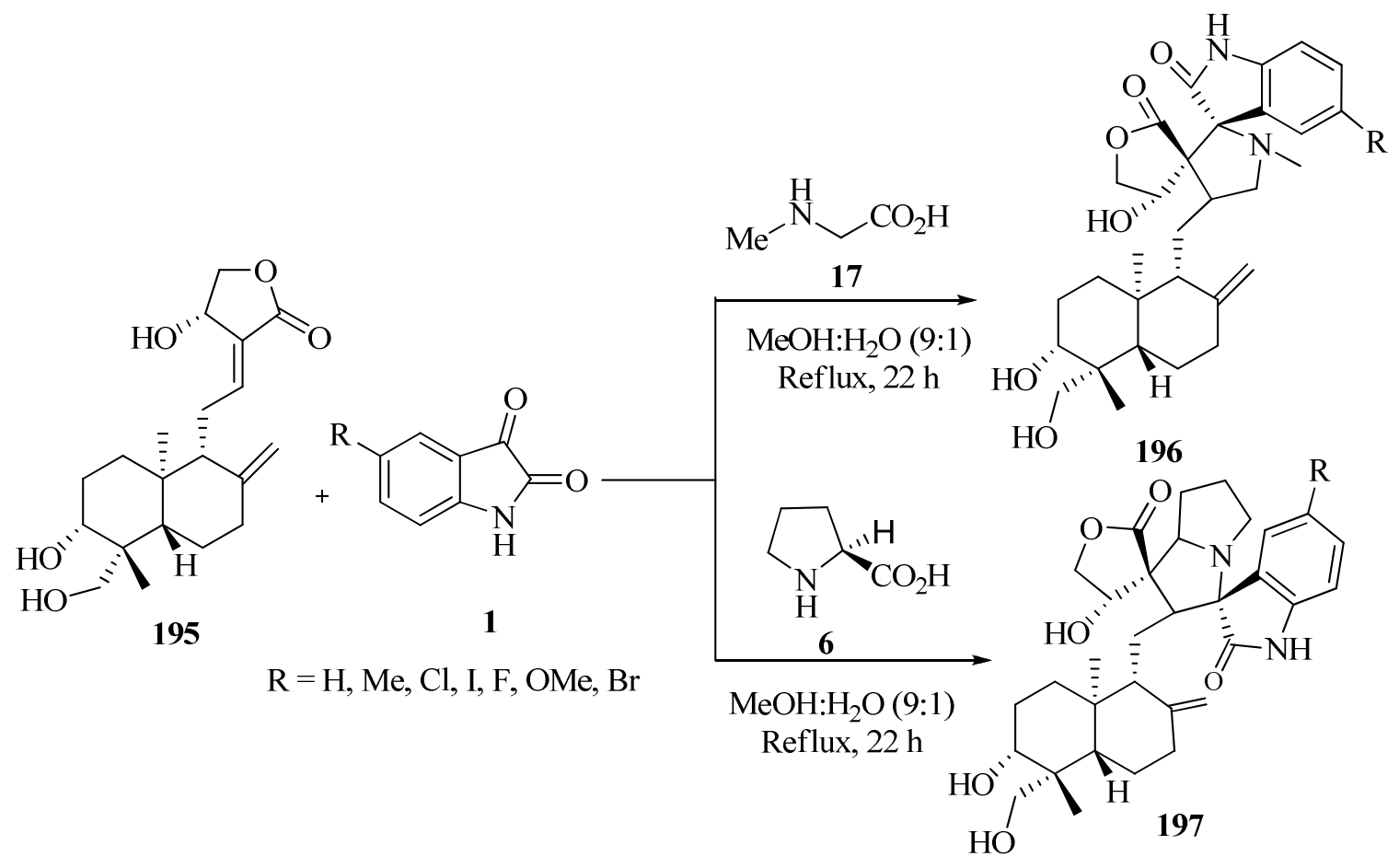

\section{Scheme 56}

Domino reactions of isatin, and sarcosine ${ }^{74}$ or phenylglycine, ${ }^{75}$ furnishing highly functionalised dispiropyrrolidines 200-203 in moderate yields, have been described. When the reaction was performed with L-proline and congeners it resulted in the dimeric azomethine ylides 204 (Scheme 57). ${ }^{75}$ These compounds were screened for their antimycobacterial activities.

$\beta, \beta$ '-Bis-spiro derivatives of oxindole 207 were prepared by dipolar [3+2] cycloaddition to isoindigo derivatives 206, obtained from oxindole 205 and isatin derivatives. The azomethine ylide was generated in situ from sarcosine and paraformaldehyde (Scheme 58). ${ }^{76}$ Both reactions proceed with high yield and are completely diastereoselective. 


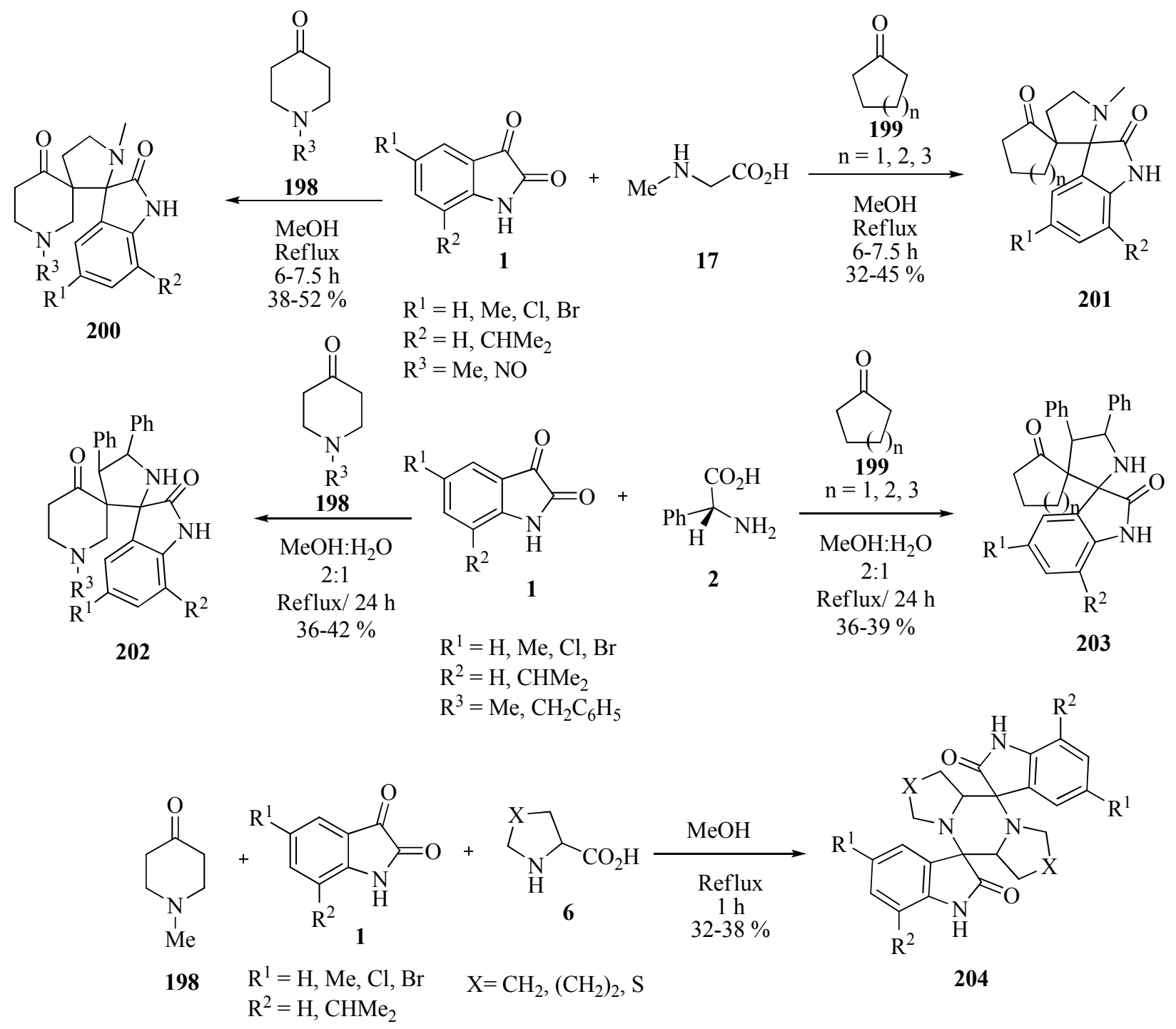

\section{Scheme 57}

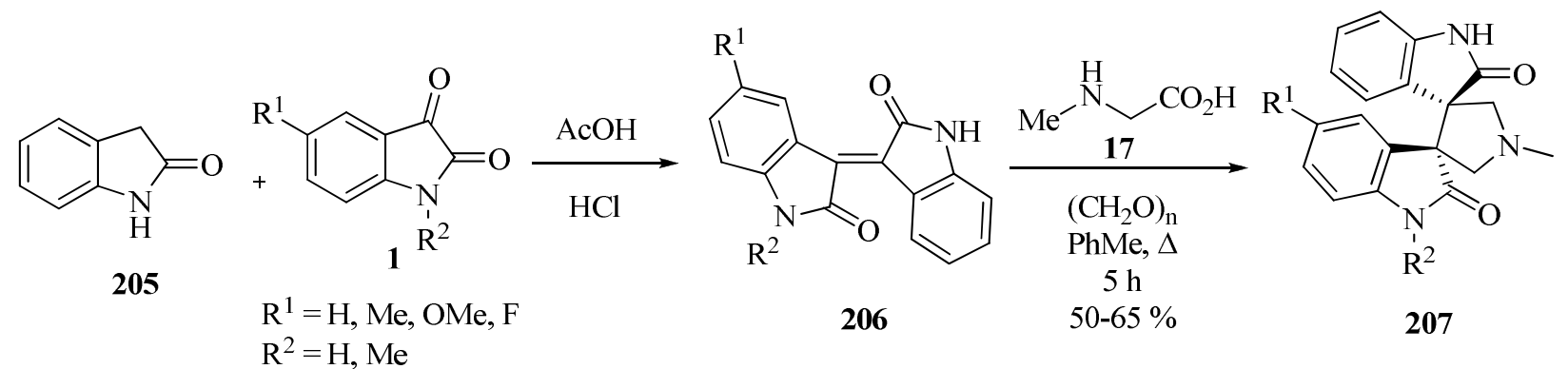

\section{Scheme 58}


A simple and efficient synthetic approach to spiropyrrolo-bicyclo[2.2.1]heptanes 209 and 210 involving 1,3-dipolar cycloaddition reaction of the azomethine ylide with (E)-3furfurylidene-4-chromanone and (E)-2-furfurylidene-1-tetralone 208 in a regio- and stereocontrolled fashion has been developed. A subsequent intermolecular Diels-Alder cycloaddition of the spiropyrrolidines with dimethyl acetylenedicarboxylate (DMAD) provided adducts 211 (Scheme 59). ${ }^{77}$

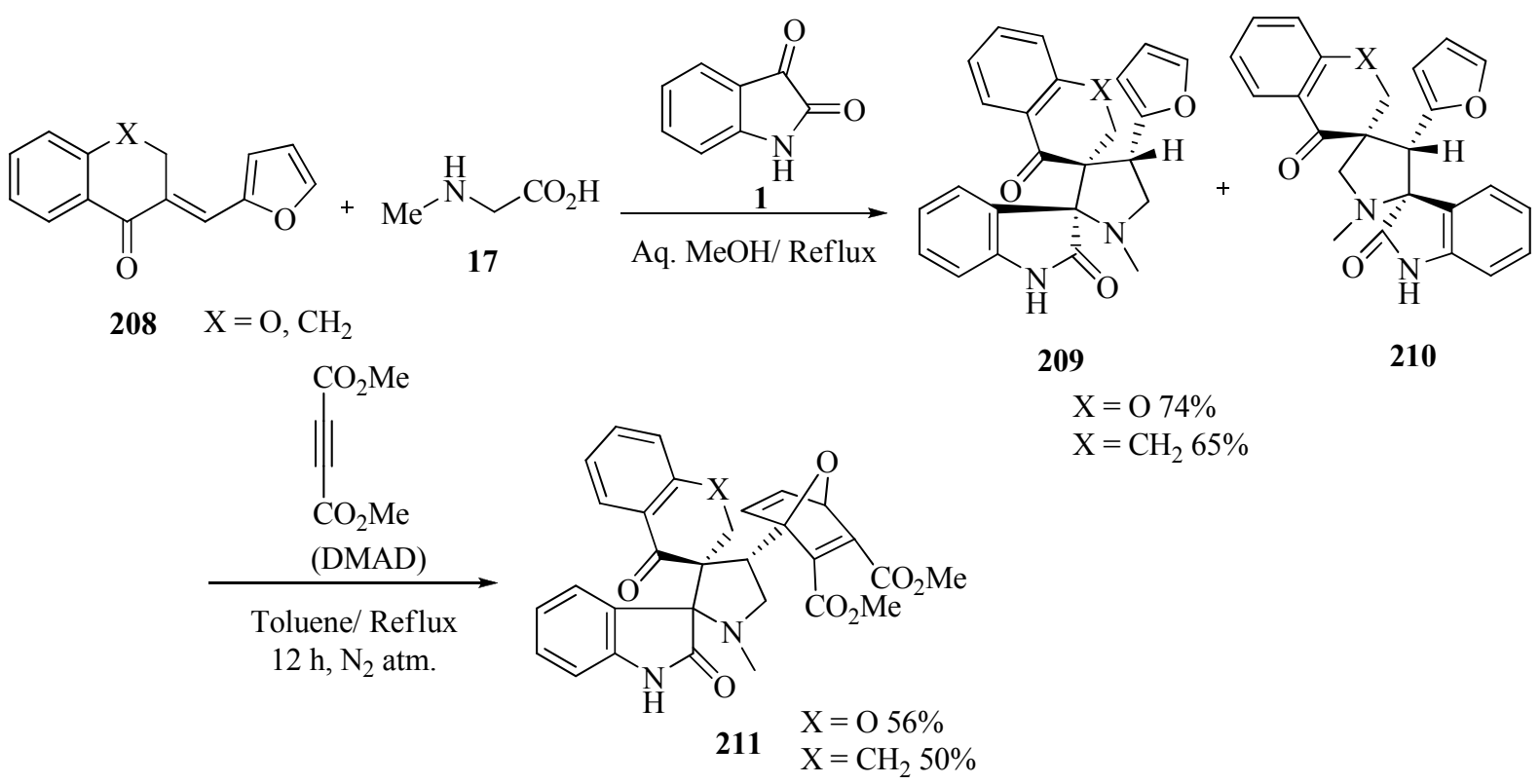

\section{Scheme 59}

3-Benzylidene-1-methylpyrrolidine-2,5-diones 212, prepared from $N$-methylmaleimide 92 and various substituted benzaldehydes 57, were used for the synthesis of biologically active dispiropyrrolidines 213 (Scheme 60). ${ }^{78}$

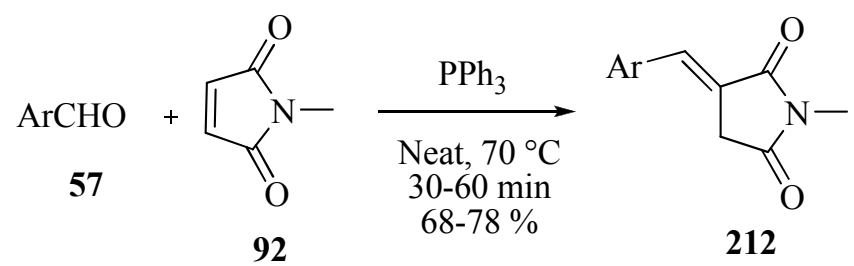<smiles>[R]N1C(=O)C(=O)c2ccccc21</smiles>

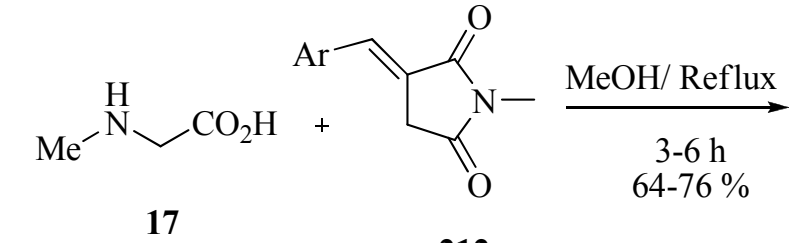

212

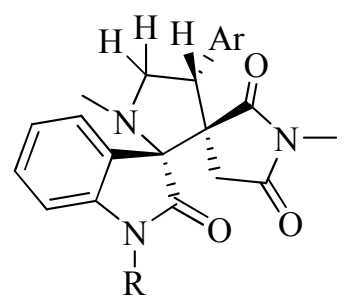

213

$\mathrm{Ar}=2-\mathrm{OHC}_{6} \mathrm{H}_{4}, 4-\mathrm{OMeC}_{6} \mathrm{H}_{4}, 4-\mathrm{ClC}_{6} \mathrm{H}_{4}, 4-\mathrm{MeC}_{6} \mathrm{H}_{4}$ $\mathrm{R}=\mathrm{H}, \mathrm{Me}, \mathrm{Bn}$, Propargyl

\section{Scheme 60}


1,3-Dipolar cycloaddition reactions of $\mathbf{1 1 5}$ with azomethine ylides generated by thermal reaction of isatin with $\alpha$-amino acids 6 and 17, forming the diindoxyl products 214 and 215, were also investigated (Scheme 61). ${ }^{79}$<smiles>COC(=O)Nc1ccc(C(=O)/C=C2\C(=O)Nc3ccccc32)cc1</smiles>

115<smiles>O=C1Nc2ccccc2C1=O</smiles>

1

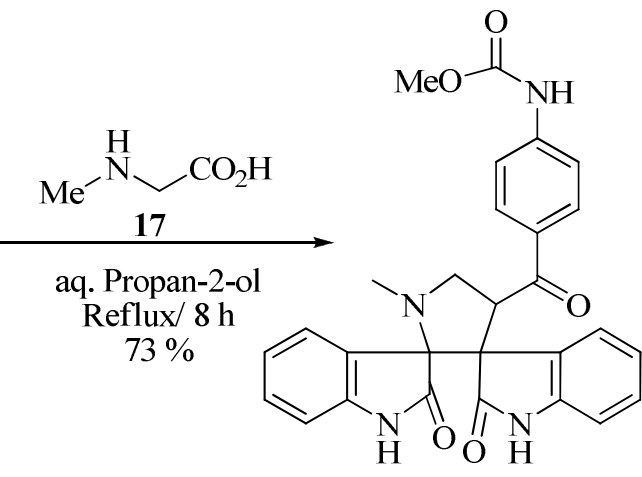

214

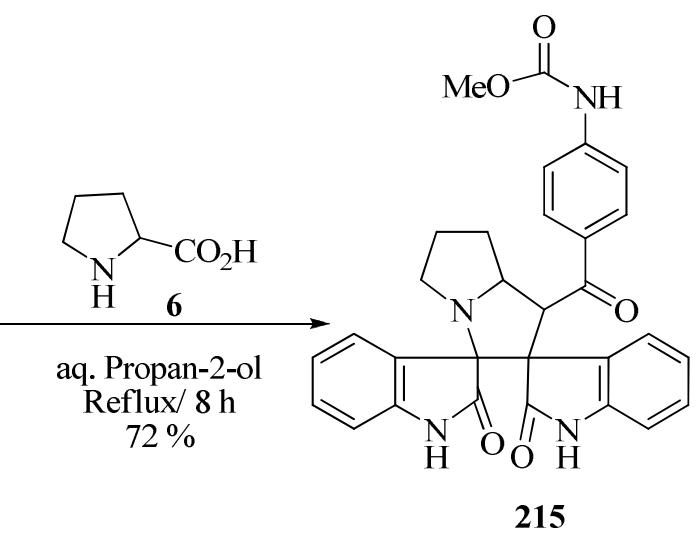

\section{Scheme 61}

\subsection{Synthesis of dispiropyrrolothiazolo-oxindoles}

Synthesis of heterocyclic compounds having both thiazolone and spirooxindole moieties via 1,3dipolar cycloaddition reaction of azomethine ylides generated in situ by the decarboxylative condensation of isatin with 1,3-thiazolane-4-carboxylic acid 135 with dipolarophiles such as $\mathbf{1 8 0},{ }^{80} \mathbf{2 1 6},{ }^{81}$ and $\mathbf{8 2}^{82}$ has been reported (Scheme 62). 


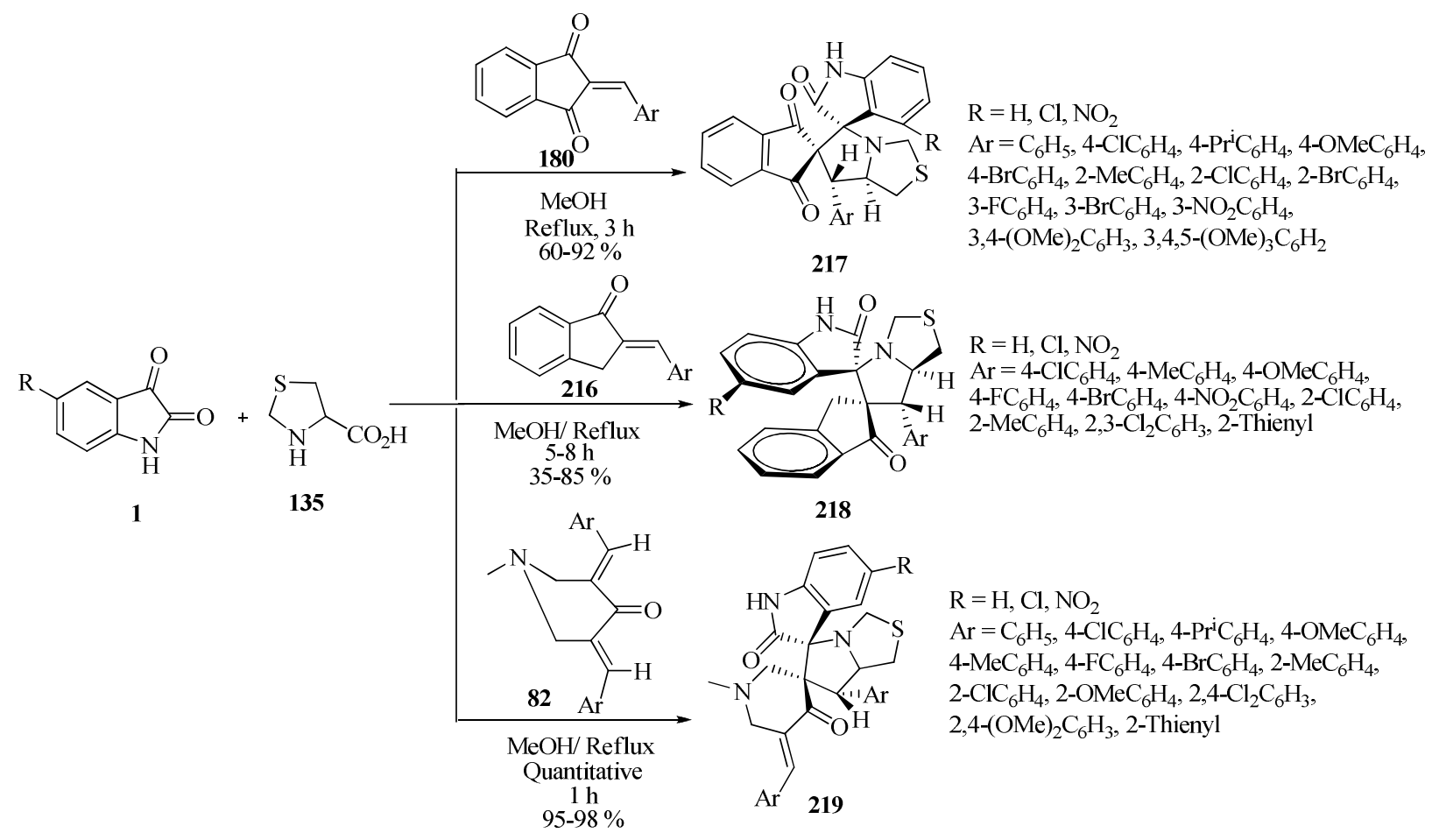

\section{Scheme 62}

Catalyst-free 1,3-dipolar cycloaddition reactions of azomethine ylides to 5-benzylidene-2thioxothiazolidin-4-one or 5-benzylidenethiazolidine-2,4-dione $\mathbf{2 2 0}$ promoted by ultrasound has been reported (Scheme 63). ${ }^{83}$ Application of sarcosine 17 and proline in this reaction was also investigated. ${ }^{84}$ The compounds synthesized were screened for their antidiabetic activity on male Wistar rats. ${ }^{85}$
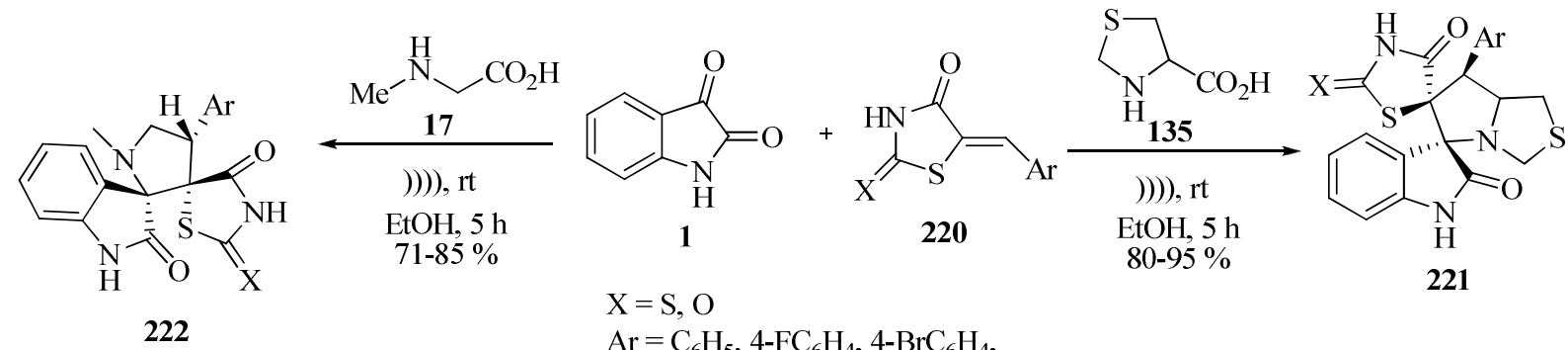

$$
\begin{aligned}
& \mathrm{X}=\mathrm{S}, \mathrm{O} \\
& \mathrm{Ar}=\mathrm{C}_{6} \mathrm{H}_{5}, 4-\mathrm{FC}_{6} \mathrm{H}_{4}, 4-\mathrm{BrC}_{6} \mathrm{H}_{4}, \\
& 4-\mathrm{NO}_{2} \mathrm{C}_{6} \mathrm{H}_{4}, 4-\mathrm{MeC}_{6} \mathrm{H}_{4}, 3-\mathrm{MeC}_{6} \mathrm{H}_{4}
\end{aligned}
$$

\section{Scheme 63}

Azomethine ylide cycloaddition to 2-arylmethylidene-6,7-dihydro-5H-thiazolo[3,2-a]pyrimidin-3-ones $\mathbf{2 2 3}$ afforded novel products regio- and stereo-selectively in moderate yields (Scheme 64) ${ }^{86}$ Further reaction of $\mathbf{2 2 5}$ with 2,6-dichlorobenzonitrile oxide $\mathbf{2 2 6}$ resulted in spirothiazolo[3,2-a]pyrimidines $227 .^{87}$ 


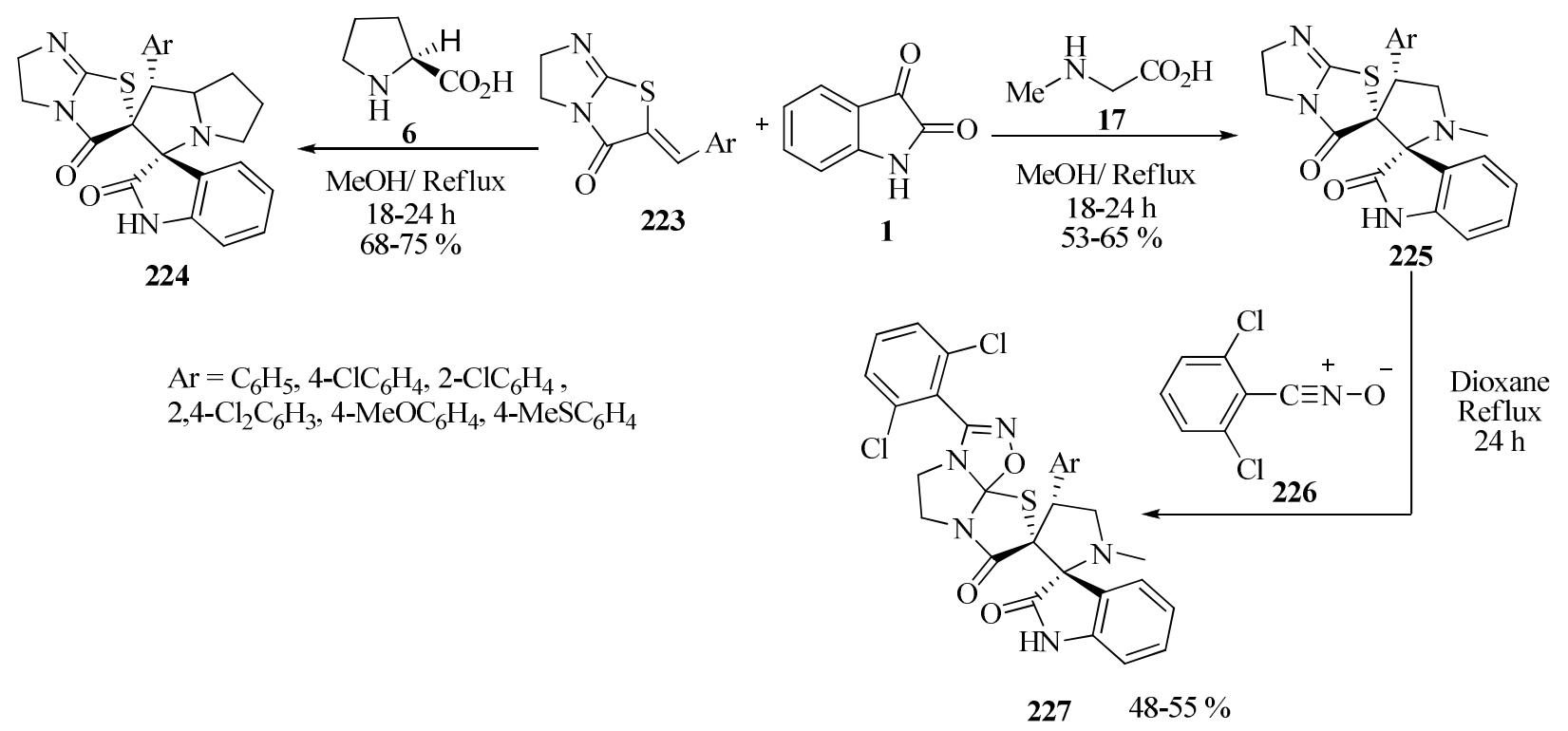

\section{Scheme 64}

Compound 228 as a dipolarophile undergoes regioselective 1,3-dipolar cycloaddition in different reaction conditions to give a new class of complex spiropyrrolidines $\mathbf{2 2 9}^{88}$ and $\mathbf{2 3 0}^{89}$ in good yields (Scheme 65).

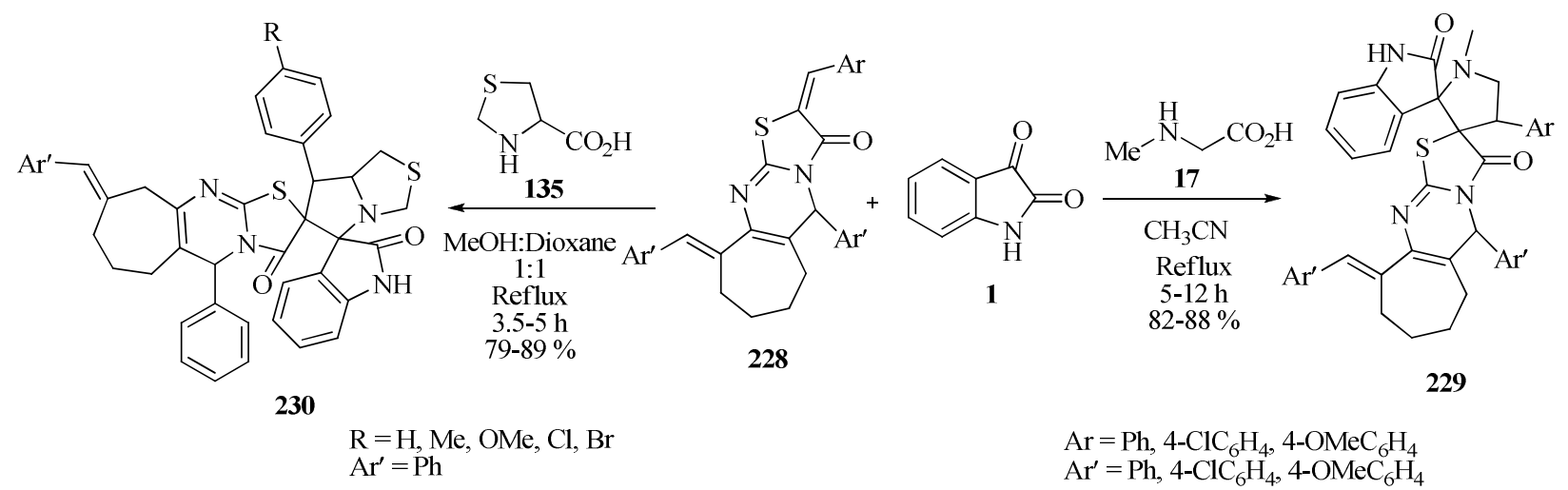

\section{Scheme 65}

7-Arylmethylidene-3-aryl-3,4-dihydro- $2 H$-thiazolo[3,2-a][1,3,5]triazin-6(7H)-one 231 was reacted with azomethine ylides to afford dispiro[oxindole-pyrrolidine]-thiazolo[3,2- $a$ ]$[1,3,5]$ triazines 232 in moderate yields (Scheme 66)..$^{90}$ 


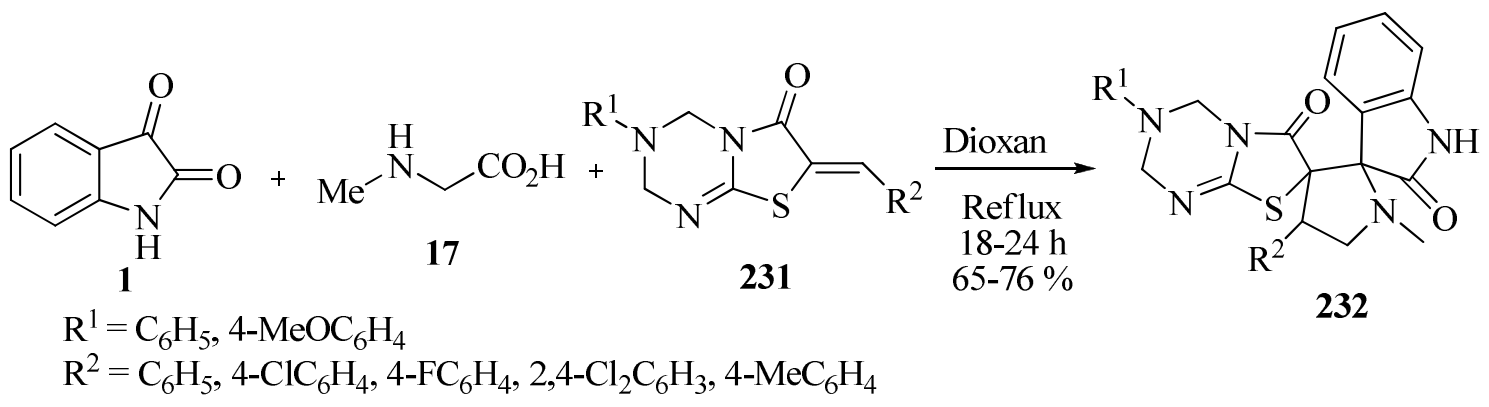

\section{Scheme 66}

The preparation of a series of spirooxindole derivatives 234 and 235 containing a spirobenzo[1,4]thiazin-3-one ring using 2-(4-methylbenzylidene)-4H-benzo[1,4]thiazin-3-one 233 as dipolarophile has been reported (Scheme 67). ${ }^{91}$

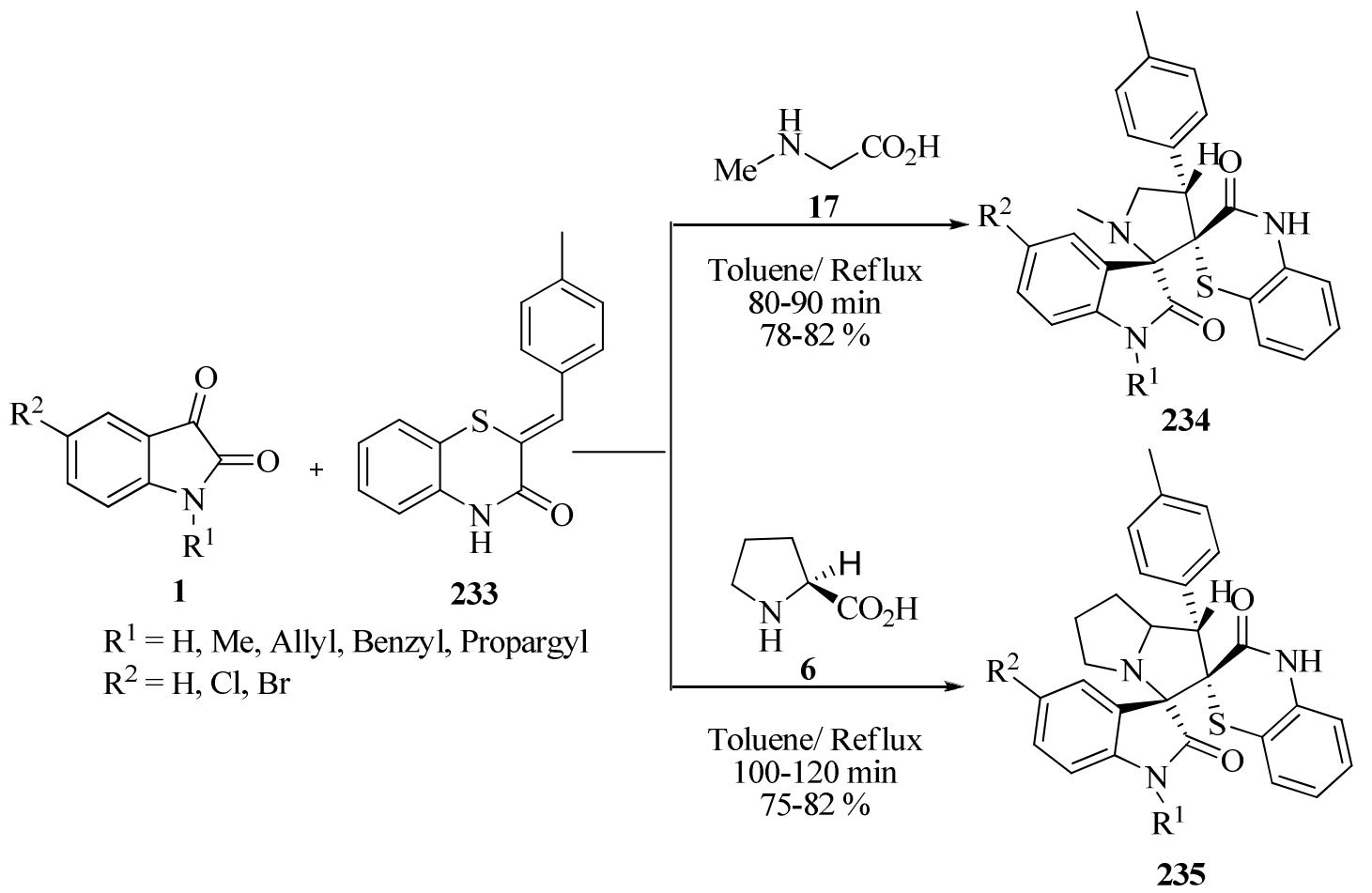

\section{Scheme 67}

\section{Synthesis of Trispiroheterocycles}

$\mathrm{Li}$ and coworkers investigated the synthesis of novel dispiropyrrolidines via azomethine ylide cycloaddition to 1-benzyl-3,5-diarylmethylidene-4-piperidinone 236 and subsequent cycloaddition with nitrile oxide $\mathbf{2 2 6}$ to obtain novel tri-spiro heterocycles 238 (Scheme 68 ). ${ }^{92}$ 


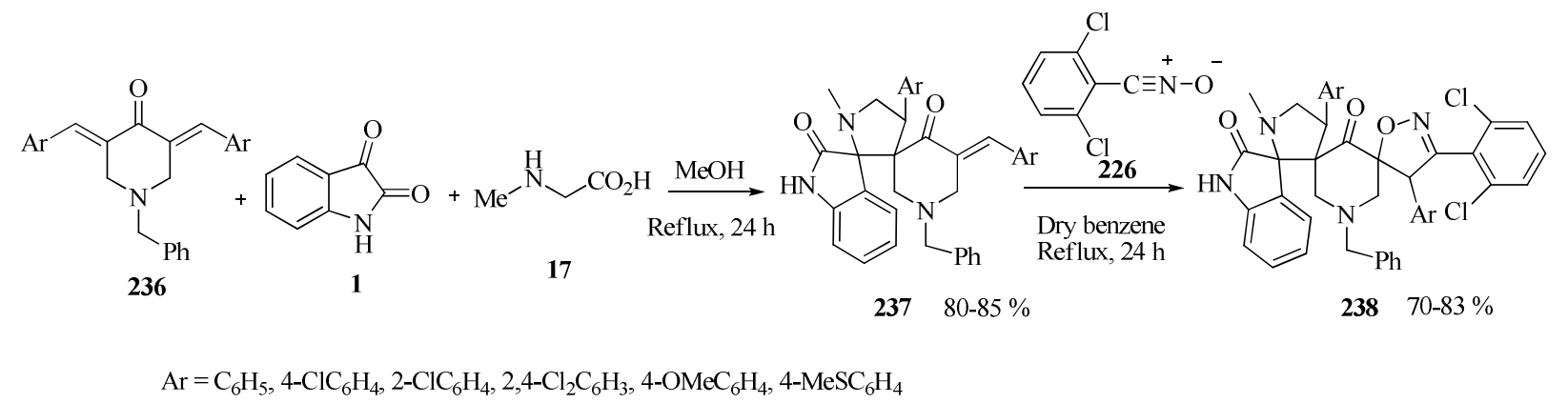

\section{Scheme 68}

2,5-Bis(arylmethylidene)-cyclopentanones 239 as dipolarophiles have been used for the synthesis of novel dispiro oxindole/pyrrolidines in moderate yields. Further cycloaddition of compound 240 with nitrile oxide 226 afforded 241 with high regio- and stereoselectivity (Scheme 69). ${ }^{93}$

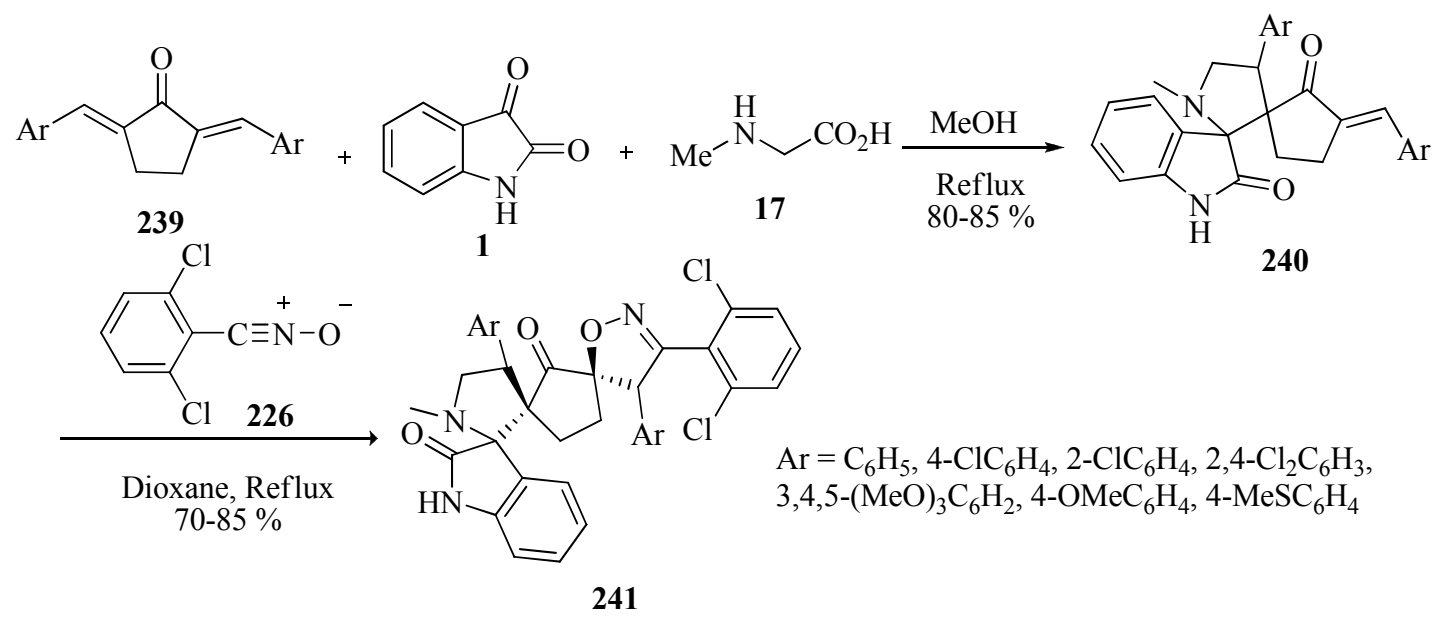

\section{Scheme 69}

\section{Synthesis of Tetraspiroheterocycles}

The facile synthesis of tetraspiro-bisoxindolopyrrolidine derivatives 244 , in a highly regio- and stereoselective manner through 1,3-dipolar cycloaddition of bis-dipolarophiles 242 with the 1,3dipole generated from isatins and sarcosine, has been reported (Scheme 70). ${ }^{94}$ 


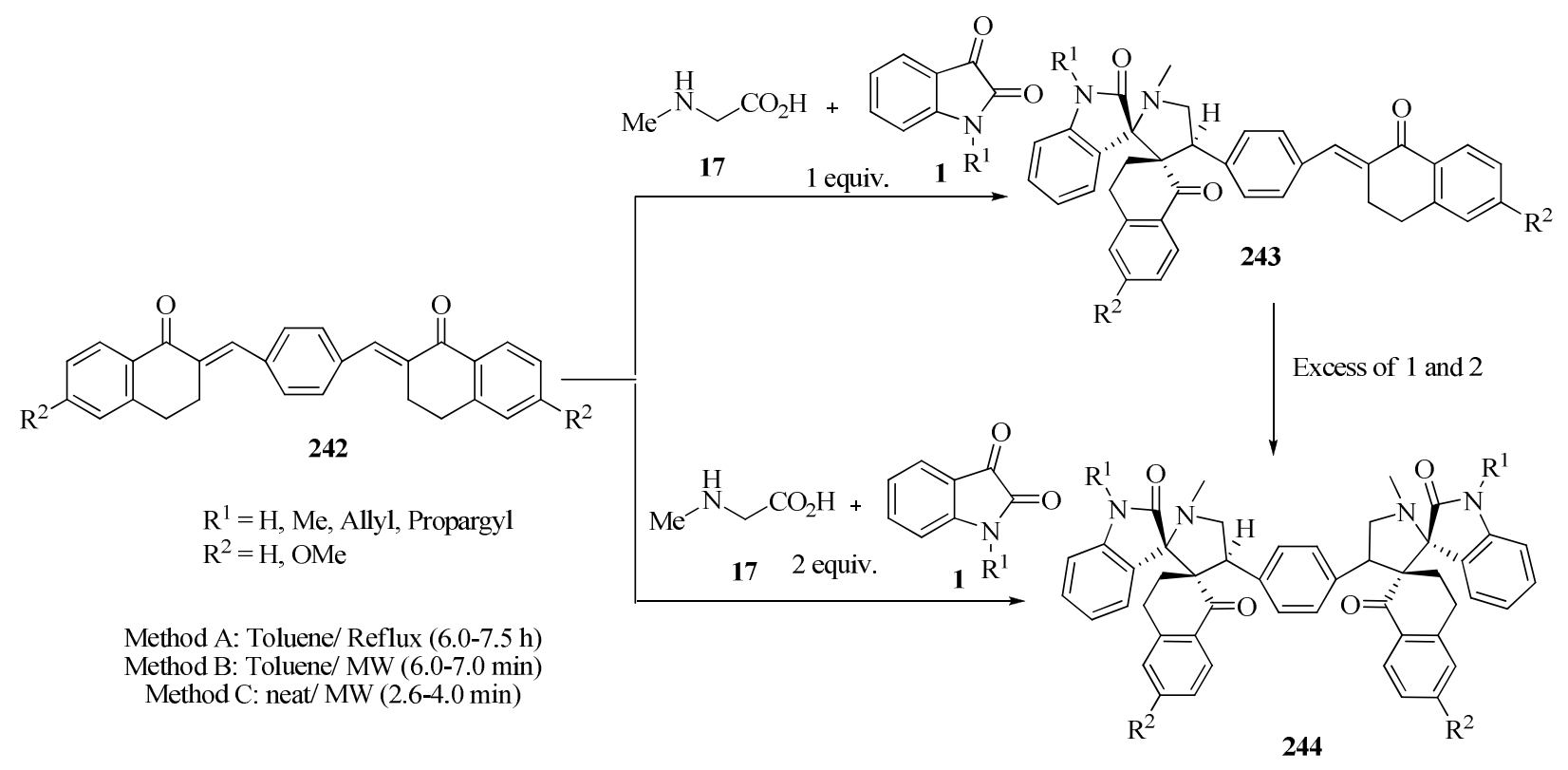

Scheme 70

\section{Acknowledgements}

We are grateful for financial support from the Research Council of Alzahra University.

\section{References}

1. Da Silva, J. F. M.; Garden, S. J.; Pinto, A. C. J. Braz. Chem. Soc. 2001, 12, 273.

2. (a) Batanero, B.; Barba, F. Tetrahedron Lett. 2006, 47, 8201. (b) Deng, H.; Konopelski, J. P. Org. Lett. 2001, 3, 3001. (c) Jahng, K. C.; Kim, S. I.; Kim, D. H.; Seo, C. S.; Son, J. -K.; Lee, S. H.; Lee, E. S.; Jahng, Y. Chem. Pharm. Bull. 2008, 56, 607. (d) Kitajima, M.; Mori, I.; Arai, K.; Kogure, N.; Takayama, H. Tetrahedron Lett. 2006, 47, 3199. (e) Lee, E. S.; Park, J. -G.; Jahng, Y. Tetrahedron Lett. 2003, 44, 1883. (f) Overman, L. E.; Peterson, E. A. Angew. Chem. Int. Ed. 2003, 42, 2525. (g) Sun, C.; Lin, X.; Weinreb, S. M. J. Org. Chem. 2006, 71, 3159. (h) Torres, J. C.; Pinto, A. C.; Garden, S. J. Tetrahedron 2004, 60, 9889. (i) Trost, B.; Brennan, M. Synthesis 2009, 3003.

3. (a) Aboul-Fadl, T.; Bin-Jubair, F. A. S.; Aboul-Wafa, O. Eur. J. Med. Chem. 2010, 45, 4578.

(b) Gupta, L.; Sunduru, N.; Verma, A.; Srivastava, S.; Gupta, S.; Goyal, N.; Chauhan, P. M.

S. Eur. J. Med. Chem. 2010, 45, 2359. (c) Shibinskaya, M. O.; Lyakhov, S. A.; Mazepa, A. V.; Andronati, S. A.; Turov, A. V.; Zholobak, N. M.; Spivak, N. Y. Eur. J. Med. Chem. 2010, 45, 1237. (d) Bandekar, P. P.; Roopnarine, K. A.; Parekh, V. J.; Mitchell, T. R.; Novak, M. J.; Sinden, R. R. J. Med. Chem. 2010, 53, 3558. (e) Bhattacharjee, A. K.; Skanchy, D. J.; 
Jennings, B.; Hudson, T. H.; Brendle, J. J.; Werbovetz, K. A. Bioorg. Med. Chem. 2002, 10, 1979. (f) Nguyen, Q. -D.; Aboagye, E. O. Integr. Biol. 2010, 2, 483.

4. (a) Doménech, A.; Doménech-Carbó, M. T.; Sánchez del Río, M.; Vázquez de Agredos Pascual, M. L.; Lima, E. New J. Chem. 2009, 33, 237. (b) Ferreira, E. S. B.; Hulme, A. N.; McNab, H.; Quye, A. Chem. Soc. Rev. 2004, 33, 329.

5. (a) Kassab, S.; Hegazy, G.; Eid, N.; Amin, K.; El-Gendy, A. Nucleosides, Nucleotides Nucleic Acids 2010, 29, 72. (b) Sridhar, S. K.; Saravanan, M.; Ramesh, A. Eur. J. Med. Chem. 2001, 36, 615. (c) Singh, U. K.; Pandeya, S. N.; Singh, A.; Srivastava, B. K.; Pandey, M. Int. J. Pharm. Sci. Drug Res. 2010, 2, 151.

6. (a) Amal Raj, A.; Raghunathan, R.; SrideviKumari, M. R.; Raman, N. Bioorg. Med. Chem. 2003, 11, 407. (b) Rodríguez-Argüelles, M. C.; Mosquera-Vázquez, S.; Tourón-Touceda, P.; Sanmartín-Matalobos, J.; García-Deibe, A. M.; Belicchi-Ferrari, M.; Pelosi, G.; Pelizzi, C.; Zani, F. J. Inorg. Biochem. 2007, 101, 138. (c) Dandia, A.; Singh, R.; Khaturia, S.; Mérienne, C.; Morgant, G.; Loupy, A. Bioorg. Med. Chem. 2006, 14, 2409.

7. (a) Quenelle, D.; Keith, K.; Kern, E. Antiviral Res. 2006, 71, 24. (b) Jiang, T.; Kuhen, K. L.; Wolff, K.; Yin, H.; Bieza, K.; Caldwell, J.; Bursulaya, B.; Tuntland, T.; Zhang, K.; Karanewsky, D. Bioorg. Med. Chem. Lett. 2006, 16, 2109. (c) Jarrahpour, A.; Khalili, D.; De Clercq, E.; Salmi, C.; Brunel, J. M. Molecules 2007, 12, 1720.

8. (a) Bal, T. R.; Anand, B.; Yogeeswari, P.; Sriram, D. Bioorg. Med. Chem. Lett. 2005, 15, 4451. (b) Sriram, D.; Yogeeswari, P.; Myneedu, N. S.; Saraswat, V. Bioorg. Med. Chem. Lett. 2006, 16, 2127. (c) Pandeya, S. N.; Sriram, D.; Nath, G.; De Clercq, E. Eur. J. Med. Chem. 2000, 35, 249.

9. (a) Karalı, N.; Gürsoy, A.; Kandemirli, F.; Shvets, N.; Kaynak, F. B.; Özbey, S.; Kovalishyn, V.; Dimoglo, A. Bioorg. Med. Chem. 2007, 15, 5888. (b) Feng, L. -S.; Liu, M. -L.; Wang, B.; Chai, Y.; Hao, X. -Q.; Meng, S.; Guo, H. -Y. Eur. J. Med. Chem. 2010, 45, 3407. (c) Sriram, D.; Yogeeswari, P.; Basha, J. S.; Radha, D. R.; Nagaraja, V. Bioorg. Med. Chem. 2005, 13, 5774.

10. Gürsoy, A.; Karal1, N. Eur. J. Med. Chem. 2003, 38, 633.

11. Sridhar, S. K.; Ramesh, A. Biol. Pharm. Bull. 2001, 24, 1149.

12. Verma, M.; Pandeya, S. N.; Singh, K. N.; Stables, J. P. Acta Pharm. 2004, 54, 49.

13. (a) Huisgen, R. Angew. Chem. Int. Ed. 1963, 2, 633. (b) Huisgen, R. Angew. Chem. Int. Ed. 1963, 2, 565 .

14. Rehn, S.; Bergman, J.; Stensland, B. Eur. J. Org. Chem. 2004, 2004, 413.

15. Xie, Y. M.; Yao, Y. Q.; Sun, H. B.; Yan, T. T.; Liu, J.; Kang, T. R. Molecules 2011, 16, 8745. 16. Alimohammadi, K.; Sarrafi, Y.; Tajbakhsh, M.; Yeganegi, S.; Hamzehloueian, M. Tetrahedron 2011, 67, 1589.

17. Chen, G.; Yang, J.; Gao, S.; He, H.; Li, S.; Di, Y.; Chang, Y.; Lu, Y.; Hao, X. Mol. Divers. 2012, 16, 151.

18. Rajesh, S. M.; Perumal, S.; Menéndez, J. C.; Yogeeswari, P.; Sriram, D. Med. Chem. Commun. 2011, 2, 626. 
19. Poornachandran, M.; Muruganantham, R.; Raghunathan, R. Synth. Commun. 2006, 36, 141.

20. Ghandi, M.; Taheri, A.; Abbasi, A. Tetrahedron 2010, 66, 6744.

21. Chen, H.; Wang, S. Y.; Xu, X. P.; Ji, S. J. Synth. Commun. 2011, 41, 3280.

22. Prasanna, R.; Purushothaman, S.; Raghunathan, R. Tetrahedron Lett. 2010, 51, 4538.

23. Hemamalini, A.; Nagarajan, S.; Ravinder, P.; Subramanian, V.; Das, T. M. Synthesis 2011, 2495.

24. Barman, P. D.; Sanyal, I.; Mandal, S. B.; Banerjee, A. K. Synthesis 2011, 3563.

25. Tabatabaei Rezaei, S. J.; Nabid, M. R.; Yari, A.; Ng, S. W. Ultrason. Sonochem. 2011, 18, 49.

26. Murugan, R.; Raghunathan, R.; Narayanan, S. S. Synth. Commun. 2010, 40, 3135.

27. Nair, V.; Sheela, K. C.; Rath, N. P.; Eigendorf, G. K. Tetrahedron Lett. 2000, 41, 6217.

28. Saravanan, P.; Babu, A. R. S.; Raghunathan, R. Synth. Commun. 2010, 40, 2329.

29. Liu, X. G.; Feng, Y. Q.; Tan, C. J.; Chen, H. L. Synth. Commun. 2006, 36, 2655.

30. Suresh Babu, A. R.; Raghunathan, R. Tetrahedron Lett. 2008, 49, 4487.

31. Suresh Babu, A. R.; Raghunathan, R.; Baskaran, S. Tetrahedron 2009, 65, 2239.

32. Ghandi, M.; Yari, A.; Rezaei, S. J. T.; Taheri, A. Tetrahedron Lett. 2009, 50, 4724.

33. Ji, S. -J.; Xu, X. -P.; Zhao, K.; Zhu, S. -L.; Shi, D. -Q. Synthesis 2010, 1793.

34. Ganguly, A. K.; Seah, N.; Popov, V.; Wang, C. H.; Kuang, R.; Saksena, A. K.; Pramanik, B. N.; Chan, T. M.; McPhail, A. T. Tetrahedron Lett. 2002, 43, 8981.

35. Jayashankaran, J.; Manian, R. D. R. S.; Sivaguru, M.; Raghunathan, R. Tetrahedron Lett. 2006, 47, 5535.

36. Lakshmi, N. V.; Thirumurugan, P.; Jayakumar, C.; Perumal, P. T. Synlett 2010, 955.

37. Thangamani, A. Eur. J. Med. Chem. 2010, 45, 6120.

38. Pardasani, R. T.; Pardasani, P.; Chaturvedi, V.; Yadav, S. K.; Saxena, A.; Sharma, I. Heteroat. Chem. 2003, 14, 36.

39. Ranjith Kumar, R.; Perumal, S. Tetrahedron 2007, 63, 12220.

40. Lakshmi, N. V.; Arun, Y.; Perumal, P. T. Tetrahedron Lett. 2011, $52,3437$.

41. Dondas, H. A.; Fishwick, C. W. G.; Grigg, R.; Kilner, C. Tetrahedron 2004, 60, 3473.

42. Selvakumar, K.; Vaithiyanathan, V.; Shanmugam, P. Chem. Commun. 2010, 46, 2826.

43. Raunak; Kumar, V.; Mukherjee, S.; Poonam; Prasad, A. K.; Olsen, C. E.; Schäffer, S. J. C.; Sharma, S. K.; Watterson, A. C.; Errington, W. Tetrahedron 2005, 61, 5687.

44. Mehrdad, M.; Faraji, L.; Jadidi, K.; Eslami, P.; Sureni, H. Monatsh. Chem. 2011, 142, 917.

45. Bouhfid, R.; Joly, N.; Essassi, E. M.; Lequart, V.; Massoui, M.; Martin, P. Synth. Commun. 2011, 41, 2096.

46. Velikorodov, A. V.; Imasheva, N. M.; Kuanchalieva, A. K.; Poddubnyi, O. Y. Russ. J. Org. Chem. 2010, 46, 971.

47. Azizian, J.; Morady, A. V.; Soozangarzadeh, S.; Asadi, A. Tetrahedron Lett. 2002, 43, 9721.

48. Galliford, C. V.; Martenson, J. S.; Stern, C.; Scheidt, K. A. Chem. Commun. 2007, 631.

49. Muthusamy, S. Tetrahedron 2003, 59, 8117. 
50. Jain, S.; Khanna, P.; Bhagat, S.; Jain, M.; Sakhuja, R. Phosphorus, Sulfur, Silicon Relat. Elem. 2005, 180, 1829.

51. Pardasani, P.; Pardasani, R. T.; Sherry, D.; Chaturvedi, V. Synth. Commun. 2002, 32, 435.

52. Subramaniyan, G.; Raghunathan, R.; Nethaji, M. Tetrahedron 2002, 58, 9075.

53. Manian, R. D. R. S.; Jayashankaran, J.; Raghunathan, R. Synth. Commun. 2003, 33, 4053.

54. Amal Raj, A.; Raghunathan, R. Synth. Commun. 2003, 33, 1131.

55. Amal Raj, A.; Raghunathan, R. Synth. Commun. 2003, 33, 421.

56. Subramaniyan, G.; Raghunathan, R. Synth. Commun. 2004, 34, 1825.

57. Periyasami, G.; Raghunathan, R.; Surendiran, G.; Mathivanan, N. Bioorg. Med. Chem. Lett. 2008, 18, 2342.

58. Maheswari, S. U.; Perumal, S.; Almansour, A. I. Tetrahedron Lett. 2012, 53, 349.

59. Ge, S.; Hua, Y.; Xia, M. Ultrason. Sonochem. 2009, 16, 232.

60. Poornachandran, M.; Jayagobi, M.; Raghunathan, R. Synth. Commun. 2010, 40, 551.

61. Jayashankaran, J.; Manian, R. D. R. S.; Raghunathan, R. Tetrahedron Lett. 2004, 45, 7303.

62. Dandia, A.; Jain, A. K.; Bhati, D. S. Tetrahedron Lett. 2011, 52, 5333.

63. Liu, H.; Dou, G.; Shi, D. J. Comb. Chem. 2010, 12, 292.

64. Lakshmi, N. V.; Thirumurugan, P.; Perumal, P. T. Tetrahedron Lett. 2010, 51, 1064.

65. Li, M.; Yang, W. -L.; Wen, L. -R.; Li, F. -Q. Eur. J. Org. Chem. 2008, 2008, 2751.

66. Suresh Babu, A. R.; Raghunathan, R.; Gayatri, G.; Sastry, G. N. J. Heterocycl. Chem. 2006, 43, 1467.

67. Suresh Babu, A. R.; Raghunathan, R. Tetrahedron 2007, 63, 8010.

68. Sridhar, G.; Raghunathan, R. Synth. Commun. 2006, 36, 21.

69. Jayashankaran, J.; Manian, R. D. R. S.; Venkatesan, R.; Raghunathan, R. Tetrahedron 2005, $61,5595$.

70. Amal Raj, A.; Raghunathan, R. Tetrahedron 2001, 57, 10293.

71. Babu, A. R. S.; Raghunathan, R. Tetrahedron Lett. 2008, 49, 4618.

72. El-Ahl, A. S. Heteroat. Chem. 2002, 13, 324.

73. Hazra, A.; Paira, P.; Sahu, K. B.; Naskar, S.; Saha, P.; Paira, R.; Mondal, S.; Maity, A.; Luger, P.; Weber, M.; Mondal, N. B.; Banerjee, S. Tetrahedron Lett. 2010, 51, 1585.

74. Suresh Kumar, R.; Perumal, S. Tetrahedron Lett. 2007, 48, 7164.

75. Kumar, R. S.; Rajesh, S. M.; Perumal, S.; Banerjee, D.; Yogeeswari, P.; Sriram, D. Eur. J. Med. Chem. 2010, 45, 411.

76. Shvets, A. A.; Kurbatov, S. V. Chem. Heterocycl. Compd. 2009, 45, 866.

77. Manian, R. D. R. S.; Jayashankaran, J.; Kumar, S. S.; Raghunathan, R. Tetrahedron Lett. 2006, 47, 829.

78. Karthikeyan, K.; Sivakumar, P. M.; Doble, M.; Perumal, P. T. Eur. J. Med. Chem. 2010, 45, 3446.

79. Velikorodov, A. V.; Poddubnyi, O. Y.; Krivosheev, O. O.; Titova, O. L. Russ. J. Org. Chem. 2011, 47, 402. 
80. Maheswari, S. U.; Balamurugan, K.; Perumal, S.; Yogeeswari, P.; Sriram, D. Bioorg. Med. Chem. Lett. 2010, 20, 7278.

81. Prasanna, P.; Balamurugan, K.; Perumal, S.; Yogeeswari, P.; Sriram, D. Eur. J. Med. Chem. 2010, 45, 5653.

82. Karthikeyan, S. V.; Bala, B. D.; Raja, V. P. A.; Perumal, S.; Yogeeswari, P.; Sriram, D. Bioorg. Med. Chem. Lett. 2010, 20, 350.

83. Hu, Y.; Zou, Y.; Wu, H.; Shi, D. Ultrason. Sonochem. 2012, 19, 264.

84. (a) Liu, H.; Zou, Y.; Hu, Y.; Shi, D. Q. J. Heterocycl. Chem. 2011, 48, 877. (b) Ponnala, S.; Kumar, R.; Maulik, P. R.; Sahu, D. P. J. Heterocycl. Chem. 2006, 43, 1635.

85. Murugan, R.; Anbazhagan, S.; Sriman Narayanan, S. Eur. J. Med. Chem. 2009, 44, 3272.

86. Li, X.; Zheng, A.; Liu, B.; Yu, X.; Yi, P. Chin. J. Chem. 2010, $28,1207$.

87. Li, X.; Zheng, A.; Liu, B.; Li, G.; Yu, X.; Yi, P. J. Heterocycl. Chem. 2011, 48, 776.

88. Hu, X. F.; Feng, Y. Q. Synth. Commun. 2005, 35, 1747.

89. Poornachandran, M.; Raghunathan, R. Tetrahedron 2006, 62, 11274.

90. Li, X.; Li, Z.; Zheng, A.; Li, G.; Yu, X.; Yi, P. J. Heterocycl. Chem. 2011, 48, 836.

91. Lakshmi, N. V.; Tamilisai, R.; Perumal, P. T. Tetrahedron Lett. 2011, 52, 5301.

92. Li, X.; Yu, X.; Yi, P. Chin. J. Chem. 2010, 28, 434.

93. Li, X.; Zheng, A.; Liu, B.; Yu, X.; Yi, P. J. Heterocycl. Chem. 2010, 47, 1157.

94. Rajesh, R.; Raghunathan, R. Tetrahedron Lett. 2010, 51, 5845.

\section{Authors' Biographies}

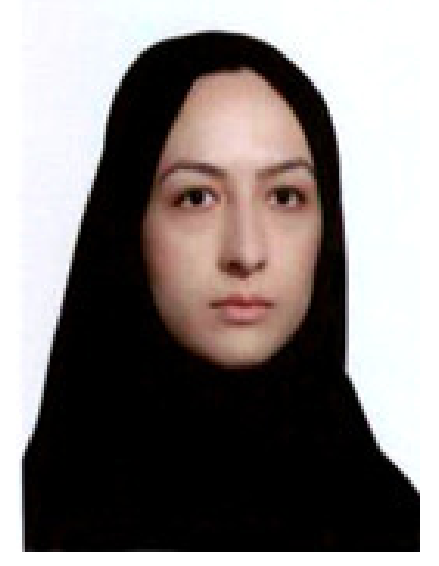

\section{Negar Lashgari}

Negar Lashgari was born in 1985 in Tehran, Iran. She received her BSc. degree in Applied Chemistry from Tarbiat Moalem University, Tehran, Iran (2008) and her MSc. degree in Organic Chemistry at Alzahra University, Tehran, Iran (2011) under the supervision of Dr Ghodsi Mohammadi Ziarani. Her research field is on the synthesis of isatin based heterocyclic 
compounds and the application of nano-heterogeneous catalysts in organic synthesis and multicomponent reactions.

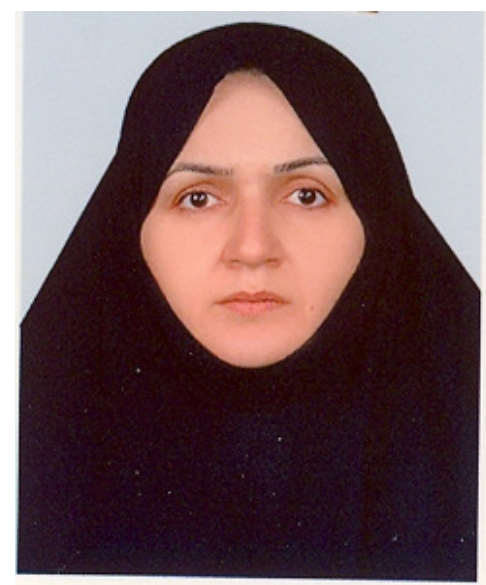

Ghodsi Mohammadi Ziarani was born in Iran, in 1964. She received her BSc. degree in Chemistry from Teacher Training University, Tehran, Iran, in 1987, her MSc. degree in Organic Chemistry from the Teacher Training University, Tehran, Iran, with Professor Jafar Asgarin and Mohammad Ali Bigdeli in 1991 and her $\mathrm{PhD}$. degree in asymmetric synthesis (Biotransformation) from Laval University, Quebec, Canada with Professor Chenevert, in 2000. She is Associate Professor in the Science faculty of Alzahra University. Her research interests include organic synthesis, heterocyclic synthesis, asymmetric synthesis, synthesis of natural products, synthetic methodology and applications of nano-heterogeneous catalysts in one pot reactions. 